REVISTA DE DERECHO UNED, NÚM. 17, 2015

\title{
LAS RESPONSABILIDADES DE LOS ÁRBITROS
}

\author{
THE LIABILITY OF THE ARBITRATORS \\ JAVIER GonZÁLEZ-SoRIa y MORENO DE LA SANTA \\ Doctor
}

Resumen: El objetivo de este artículo, basado en gran medida en un estudio jurisprudencial de las principales sentencias que han interpretado la Ley de Arbitraje de 1953, la de 1988 y la de 2003, incluida su reforma de 2011; y apoyado en la mejor doctrina científica, es crear un marco sistematizado en el que se definan claramente cuáles son las responsabilidades de los árbitros -y subsidiariamente de las Instituciones Arbitrales Permanentes-, identificando y entendiendo cuales son los hechos causantes de las mismas, la tipicidad necesaria y el resto de factores que deben concurrir para que la responsabilidad pase del ámbito abstracto al concreto. Igualmente, esta articulo profundiza en la realidad de la actuación arbitral, poniendo de manifiesto actuaciones comprometidas que deba vigilar el árbitro así como proponiendo soluciones para que el desenvolvimiento de su labor heterocompositiva se situé alejada de las líneas rojas. Para ello, en primer lugar el autor ha identificado y definido conceptual y operativamente los cinco diferentes tipos de responsabilidad (penal, civil, disciplinaria privada, administrativa, negocial y extracontractual) en los que entiende puede incurrir un árbitro en el desarrollo de sus funciones. Y posteriormente se ha centrado en la responsabilidad civil, analizando las obligaciones que ha de asumir el árbitro que pudieren resultar en responsabilidad para el mismo, a través del hilo conductor del procedimiento arbitral, distinguiendo tres momentos clave: Obligaciones anteriores a la aceptación; posteriores a la aceptación; y posteriores a la emisión del laudo.

Esto le ha llevado a interpretar cada una de esas obligaciones desde la perspectiva de la Ley 60/2003 y con la enriquecedora visión jurisprudencial, presidida por la Sentencia n. ${ }^{\circ}$ 429/2009 del Tribunal 
Supremo, Sala 1. a, de lo Civil, de 22 de Junio de 2009, con el fin de mostrar los límites de cada una de ellas y qué actuaciones con respecto a las mismas pudieran devenir en responsabilidades para el árbitro, centrándose en las que más problemática, por su complejidad o menor concreción, pudiera generar en la actuación arbitral.

Abstract: The objective of this article, mainly based on a jurisprudential study focused on the most relevant sentences interpretating the Spanish Arbitrations Law of 1953, 1988 and 2003, with its amendments dating from 2011; and supported by the most reputated scientific doctrine, is to create a systematic framework in which the liabilities of the arbitrators are clearly defined, identifying and understanding what are the facts where liabilities steam from, the required class and the rest of the elements that must concur so the liability can move from the abstract level to the real one.

On the other hand, the article studies the practice of the arbitrators, pointing out risky acts which have to be performed by the arbitrators with the utmost diligence, and proposing solutions to avoid trespassing the thin red line. Thus, first of all, the author has identified and defined conceptual and operatively five types of liability (criminal, civil, disciplinarian, administrative, negotial and extracontractual) in which the arbitrators can incurre in the development of their work. Later, he has focused on the civil liability, analyzing the obligations assumed by the arbitrators along the arbitration procedure, which is split in the three phases: obligations prior acceptance; obligations after acceptance; and obligations after issuing the arbitral award.

The author has interpreted each of these obligations from the 60/2003 Law perspective, with an enriching jurisprudential vision, established by sentence n. ${ }^{\circ}$ 429/2009, Spanish Supreme Court, to show the limits of each of them and how liability to the arbitrators can derive from them, focusing on those more problematic due to their complexity or lack of concretion.

Palabras clave: Arbitraje en España Responsabilidad del árbitro Anulación del laudo.

Keywords: Arbitration in Spain Liability of the arbitrators.

Recepción original: 8/06/2015 Aceptación original: 13/07/2015

Sumario: 1. Marco conceptual de la responsabilidad de los árbitros e instituciones arbitrales permanentes. 1.1. Responsabilidad de los Árbitros. 1.2. Responsabilidad de las Instituciones arbitrales permanentes. 2. Tipos de responsabilidades del árbitro. 2.1. Responsabi- 
lidad Penal. 2.2. Responsabilidad Disciplinaria privada. 2.3. Responsabilidad Extracontractual. 2.4. Responsabilidad Administrativa. 2.5. Responsabilidad negocial. 2.6. Responsabilidad civil. 3. Obligaciones anteriores a la aceptación del árbitro que pueden derivar en exigencias de responsabilidad civil. 3.1. Examinar su capacidad para ser árbitro. 3.2. Examinar su competencia y predisposición para ser árbitro. 3.3. Contar con un Seguro de Responsabilidad Civil. 3.4. Examinar posibles conflictos de intereses. 3.5. Examinar la viabilidad del arbitraje a tenor del convenio arbitral. 4 . Obligaciones posteriores a la aceptación del árbitro. 4.1. Obligaciones generales. 4.2. Obligación de fijar y comunicar a las partes unos honorarios y gastos de arbitraje justos.. 4.3. Obligación de determinar y conducir el procedimiento y cumplir los principios y formalidades. 4.4. Medidas cautelares. 4.5. Obligación de dictar, en tiempo oportuno, un laudo procedente, previendo que el mismo no contenga vicios que impidan que se convierta en firme y definitivo. 5. Obligaciones del árbitro posteriores a la emisión del laudo. 5.1. Protocolización del laudo. 5.2. Notificación del laudo. 5.3. Inscripción del laudo. 5.4. Resolución del recurso de aclaración. 5.5. Colaboración con la Administración de Justicia.

\section{MARCO CONCEPTUAL DE LA RESPONSABILIDAD DE LOS ÁRBITROS E INSTITUCIONES ARBITRALES PERMANENTES}

\subsection{Responsabilidad de los árbitros}

Partiendo de la teoría general de que todo hecho ilícito que cause un perjuicio trae aparejada la responsabilidad para su autor o de que todo daño injusto da derecho a una reparación a favor de aquel que lo ha sufrido, a salvo de los estatutos legales y reglamentarios que limitan o absuelven de responsabilidad a los árbitros, el principio general es que, tratándose de personas capaces, profesionales del derecho en la mayor parte de los casos, deben responder por los daños que causen en el ejercicio de sus funciones.

Sin embargo, los árbitros se asemejan a los jueces en el sentido de que desempeñan una labor jurisdiccional que requiere ser ejecutada con imparcialidad e independencia, alejada de presiones innecesarias $^{1}$. Existe una tensión natural entre el derecho común que obliga al autor de un daño a repararlo y elementos como la autoridad de la cosa juzgada, el carácter interpretativo de las normas, y la verdad ju-

${ }^{1}$ Vid. Auto del Tribunal Constitucional n. ${ }^{\circ}$ 259/1993 (Sala Primera, Sección 1. a), de 20 de julio. 
rídica en contraposición con la verdad material. No obstante, los árbitros no son jueces, carecen de investidura estatal. Son particulares, profesionales de distintos sectores, la mayoría de las veces abogados, que tienen una función transitoria que nace de una voluntad concorde de las partes que sustraen sus controversias sobre materias de libre disposición de la jurisdicción ordinaria para que sean decididas por personas independientes e imparciales ${ }^{2}$.

\subsubsection{Marco de referencia de la responsabilidad de los árbitros desde la óptica del Derecho Romano}

La historia del derecho nos demuestra que instituciones de tanta raigambre jurídica como la familia, la propiedad o el matrimonio son notablemente distintos de las instituciones que, con idénticas denominaciones jurídicas, fueron conocidas en otros momentos de dicha historia $^{3}$. Y el arbitraje no es una excepción. Y así, como bien dejó dicho DE CASTRO ${ }^{4}$, puede resultar deseable desmitificar el arbitraje: «observando que no se trata de algo dado a priori sino de una figura cambiante resultado del variado entorno social y del juego de intereses de ciertos grupos sociales». Y, por eso, para entender dicha institución creemos obligada una referencia, aunque sea sucinta, a los antecedentes históricos del arbitraje no sólo porque el conocimiento de los mismos puede servir de criterio hermenéutico de la NLAB al amparo del artículo $3 \mathrm{CC}$, sino también porque como señalaba DE CASTRO $^{5}$ : «el recuerdo de las sucesivas manifestaciones del arbitraje y el tenerlas en cuenta puede ser útil en la doctrina jurídica».

El conocer las raíces de una figura jurídica puede explicarnos algunas de sus actuales características ${ }^{6}$. Especialmente, si como seña-

${ }^{2}$ Vid. Sentencia del Tribunal Supremo (Sala de lo Civil) de 3 de marzo de 1989; Sentencia de la Audiencia Provincial de Barcelona (Sección 14.a), de 14 de noviembre de 2003; y Sentencia del Tribunal Constitucional n. ${ }^{\circ}$ 62/1991 (Pleno) de 22 de marzo de 1991.

${ }^{3}$ La familia y paterfamilias del Derecho Romano poco tienen que ver con el concepto constitucional de familia; la concepción romana de la propiedad como plena in re postestas se encuentra muy distante del concepto actual de la misma en la que su función social influye decisivamente en el concepto de la institución. Más evidente es el caso del matrimonio que en Derecho Romano era la unión de un hombre y una mujer en consorcio para toda la vida en comunicación recíproca de intereses humanos y divinos mientras que actualmente en España, tras la Ley 13/2005, de 1 de julio, se admite como matrimonio la unión de dos personas del mismo sexo y se admite que pueda disolverse sin necesidad de que concurra causa alguna.

${ }^{4} \mathrm{Vid}$. DE CASTRO Y BRAVO, F. «El arbitraje y la nueva Lex Mercatoria» Anuario de Derecho Civil, Tomo XXXII, Fascículo IV Octubre-Diciembre 1979 página 624.

${ }^{5}$ Ibidem.

${ }^{6}$ DE CASTRO Y BRAVO, F. «El arbitraje...» Op. cit. pág. 624. Como dice Cervantes en el Quijote «[...] la verdad, cuya madre es la historia, émula del tiempo, depósito de 
la FERNÁNDEZ DE BUJÁN, A.7, «del análisis de las concordancias examinadas entre el Derecho romano justinianeo y la legislación actual en materia de arbitraje, cabe deducir la base romanística del arbitraje actual, en atención a la similitud existente entre numerosos textos romanos y las normas reguladoras de los distintos aspectos y soluciones previstas en la ley española de arbitraje y en el arbitraje internacional ${ }^{8}{ }$.

Se ha señalado que «el arbitraje tiene orígenes y precedentes históricos que se confunden con la historia del derecho y de la humanidad $»^{9}$. Precisamente, por eso, es una institución tan arraigada en la historia del hombre ${ }^{10} \mathrm{y}$, por ello, tan conformadora de su ser y bien puede decirse que fue la primera forma de administrar justicia porque «históricamente la forma originaria de resolución de conflictos fue la justicia privada ${ }^{11}$. Sus orígenes se pierden en la noche de los tiempos y, sin perjuicio de interesantes referencias mitológicas ${ }^{12}$ y bíblicas $^{13}$, lo cierto es que los mismos se encuentran en la antigua Grecia ${ }^{14}$ y su configuración con los perfiles actuales se debe en gran parte

las acciones, testigo de lo pasado, ejemplo y aviso de lo presente, advertencia de lo porvenir».

${ }^{7}$ Vid. FERNÁNDEZ DE BUJÁN, ANTONIO. Bases romanísticas del arbitraje actual. Análisis de las concordancias entre el Derecho justinianeo y la legislación vigente en materia de arbitraje. Revista Crítica de Derecho Inmobiliario, N. ${ }^{\circ}$ 743, Mayo 2014.

${ }^{8} \mathrm{Cfr}$. BATY, THOMAS: The difference between arbiter in the roman sense and modern arbitrators. University of Pennsylvania, Law Review and American Law Register, vol. 65, n. ${ }^{\circ} 8,1917$.

${ }^{9} \mathrm{Vid}$. ZAPPALA, F. «Universalismo histórico del arbitraje» en Universitas Bogotá (Colombia) N. 121 pág. 196, julio-diciembre de 2010.

${ }^{10}$ Señala ZAPPALA, F. «Universalismo...» Op. cit. pág. 198 que: «Actualmente, los Bereberes o Amazigh, habitantes autóctonos del Norte de África, aplican el arbitraje primitivo como forma de dirimir los conflictos, de acuerdo con una jurisdicción especial ejercida por el sacerdote de la plaza de mercado»

${ }^{11}$ Cfr. ZAPPALA, F. «Universalismo...» Op. cit. pág. 196.

${ }^{12}$ Señala MEDINA LIMA, I. «El arbitraje privado en nuestro derecho» en Revista de la Facultad de Derecho de México, México. D. F. TXXXVIII Números 157-158-159 enero junio de 1988 pág. 158 que el pasado del arbitraje es tan lejano que se remonta a la mitología griega cuando París fue nombrado por Zeus para decidir cuál era la más bella entre las tres grandes deidades de la belleza femenina: Hera, Atenea y Afrodita, decidiéndose por esta última.

${ }^{13} \mathrm{Al}$ respecto, OGÁYAR AYLLÓN, T. «El Contrato de Compromiso y la Institución Arbitral». Ed. Revista de Derecho Privado, Editoriales de Derecho Reunidas. Madrid. 1977, pág. 38 señala como antecedente bíblico del arbitraje «el pasaje del Libro Génesis (capítulo XXXI, números 35 a 37) en el que, refiriéndose a una disputa entre Jacob y Labán por imputar éste a aquél el hurto de unos ídolos de su propiedad, propuso Jacob, para justificar su inocencia, que pusiera su equipaje a la vista de mis hermanos y de los tuyos, y sean ellos jueces entre nosotros dos».

${ }^{14}$ En la filosofía griega señala Aristóteles en su Retórica, 1.13.13, que es mejor «preferir un arbitraje más bien que un conflicto ante el tribunal, de hecho el árbitro cuida la equidad, el juez la ley; y el arbitraje ha sido inventado propiamente para 
al desarrollo que dicha institución conoce en el Derecho Romano. Por ello, la doctrina más autorizada considera que es en el Derecho Romano donde la institución del arbitraje adquirió raíces propias ${ }^{15}$. En realidad, como señala GARCÍA GARRIDO ${ }^{16}$, el arbitraje no es sino uno más de las múltiples creaciones jurídicas de Roma, pues «Los romanos son los creadores del ius gentium, aplicable a los romanos y a los peregrinos, que influye al mismo tiempo en la organización administrativa de provincias y municipios que a la extensión de las fórmulas procesales y reglas e instituciones de los ciudadanos a los extranjeros.

La stipulatio nace en la jurisdicción del pretor peregrino como institución del derecho de gentes, que como desarrollo de la primitiva informalista sponsio admite en la pregunta y respuesta el griego o cualquier otra lengua que entiendan las partes. El crédito y el contrato de buena fe, con la creación jurisprudencial-pretoria de los préstamos y de los contratos consensuales, abre nuevos medios al comercio con los extranjeros. Los principios sobre la perfección y el cumplimiento del contrato, la responsabilidad de riesgo contractual, el dolo y la culpa del deudor, los vicios ocultos, los pactos y otras muchas aportaciones, son fruto de la elaboración de los jurisprudentes romanos que han permanecido en el transcurso de los siglos.

La institución arbitral atravesó en el Derecho Romano tres fases perfectamente diferenciables: El procedimiento de las legis actionis; de la Ley de las XII tablas (450 a. C) a la Lex Aebutia (130 a. C); y Julias (17 a. C).

Aunque ya en el Tratado o Foedus Cassianum de 493 a. C que renueva la Liga Latina se contenían referencias al nombramiento de

esto, para dar fuerza a la equidad». Por su parte Platón en sus Diálogos llega a decir: «El Estado debe proporcionar a los ciudadanos tribunales donde dirimir los conflictos. Pero cuando se trata de organizar esos tribunales, la prioridad absoluta la tienen las propias partes a través del arbitraje: el más sagrado de todos los tribunales debe ser el que las partes mismas hayan creado y hayan elegido de común acuerdo». Señala ZAPPALA, F. ob. cit. pág. 199 que: «La fórmula del arbitraje surge en la cultura griega hacia el año 520 a. C., en los consejos de la confederación de pueblos y ciudades de la órbita de influencia política y militar de Atenas, denominado arbitraje de la Anfictionía, cuyo objetivo principal era resolver los conflictos entre distintos grupos étnicos por parte de 12 ancianos representantes de las diferentes tribus. En la Grecia clásica existieron también árbitros de carácter público, elegidos de manera aleatoria entre 44 patriarcas quienes juzgaban las disputas criminales y públicas [...]».

${ }^{15}$ Cfr. MURGA, J. L. «Derecho Romano Clásico II. El proceso». Publicaciones de la Universidad de Zaragoza, Tercera Edición, Zaragoza. 1989, págs. 21 y 22; D’ORS, A. «El arbitraje jurídico». En Parerga Histórica, Eunsa, Pamplona. 1997. págs. 271 a 291.

${ }^{16} \mathrm{Vid}$. GARCÍA GARRIDO, MANUEL JESÚS: La globalización del derecho de los contratos. Contratos tradición y globalización (coordinado por Moncayo Rodríguez). México. 2007, págs. 39 a 59. 
árbitros para conocer de los litigios entre ciudadanos romanos con ciudadanos no romanos ${ }^{17}$ lo cierto es que la más antigua mención del término arbiter $^{18}$ se contiene en las XII tablas (450 a. C) que crea ex novo ${ }^{19}$ la Legis Actio per iudiciis arbitrive postulationem.

Señalaba IGLESIAS SANTOS ${ }^{20}$ que «el procedimiento de las legis actiones constituye la forma más antigua de enjuiciar» y representa «el imperio de la forma, una forma angosta y embarazosa, imbuida de rito y de solemnidad ${ }^{21}$ ». Dichas acciones de ley eran cinco: legis actiones per sacramentum, per condictionem, per manus iniectionem, per pignoris capionem y per iudiciis arbitrive postulationem. Centrándonos en esta última, la misma fue creada, como ya dijimos, por la ley decenviral para exigir el cumplimiento de las obligaciones derivadas del contrato verbal de sponsio y para los procesos de división de herencia. Una Ley Licinia en torno a 210 a. C extendió esta acción cuando se pretendía la división de la cosa común. Asimismo, entiende la doctrina, que junto a las acciones divisorias señaladas (actio familiae erciscundae -o de división de herencia- y conmunni dividundo -o de división de la cosa común-) es probable que la legis actio per iudiciis arbitrive postulationem también se aplicara a la actio finium regundorum para fijar los linderos o confines controvertidos de fincas pertenecientes a distintos propietarios ${ }^{22}$.

Así, se observa como, con probabilidad, el arbitraje se encuentra unido desde el inicio de su génesis a la materia inmobiliaria pues dichos inmuebles a partir de la ley de las XII Tablas podían ser objeto de la actio conmuni dividundo, de la actio familiae erciscundae ${ }^{23}$ y de

${ }^{17}$ Cfr. FERNÁNDEZ DE BUJÁN, A. «Contribución al estudio histórico jurídico del arbitraje», Religión y Cultura LI (2005) pág. 711.

${ }^{18}$ Señala FERNÁNDEZ DE BUJÁN, A: Jurisdicción y Arbitraje en Derecho Romano. Iustel, Madrid, 2006, pág. 200 que: «el término latino arbiter que derivaría de la lengua fenicia y haría referencia a garantía conforme a la raíz fenicia rbn, se habría introducido a través del comercio en la lengua latina».

${ }^{19}$ Cfr. FERNÁNDEZ DE BUJÁN, A. Jurisdicción y Arbitraje..., Op. cit., págs. 81-82 y 87.

${ }^{20}$ Vid. IGLESIAS SANTOS, J. Derecho Romano. Instituciones de Derecho Privado. Ed. Ariel, Barcelona 1987, pág. 202.

${ }^{21}$ La fórmula solemne y rituaria -el más leve error acarreaba la pérdida del pleito- se contiene en Gayo I.4.17.y era la siguiente: El demandante decía: «Afirmo que me debes dar $\mathrm{X}$ sextercios en virtud de una promesa solemne. Te insto a que digas si es o no cierto" [Ex sponsione te mih i X milia sestertiorum dare oportere aio: id postulo aias an negues.]. La parte contraria sostenía que no era cierto y el demandante replicaba: «Puesto que lo niegas a ti Pretor te ruego que nombres a un juez o arbitro.» [Quando tu negas, te praetor iudicem sive arbitrum postulo uti des.].

22 Vid. FERNÁNDEZ DE BUJÁN, A. Jurisdicción y Arbitraje..., Op. cit. pág. 88.

${ }^{23}$ Señala GUTIERREZ MASSON, L. Del consortium a la societas. I. el Consortium Ercto no cito. Universidad Complutense de Madrid. Sección de Publicaciones. Ma- 
la actio finium regundorum. La legis actio per iudiciis arbitrive postulationem tenía como característica, además de que no se recurría al sacramentum o apuesta, que se procedía «tan pronto como se plantea la causa a la designación de juez o de árbitro sin esperar los treinta días que se exigían como plazo a respetar hasta el nombramiento de juez en la legis actio sacramento a partir de la Lex Pinaria ${ }^{24}$.

En todo caso, como sigue señalando FERNÁNDEZ DE BUJÁN, A..$^{25}$, «distingue la Ley entre Juez, iudex, y árbitro, arbiter. En el texto de Gayo se afirma que el Juez se nombraría en las reclamaciones de deuda derivadas de sponsio y el árbitro en los supuestos de división de herencia o de cosas comunes. El juez daría un iudicium y estaría sujeto a lo establecido en la fórmula verbal ante el magistrado y en la litis contestatio. El árbitro formularía un arbitrium, en el que la estimación a realizar gozaría de un mayor margen de discrecionalidad».

El extremado rigor, formalismo, rito y solemnidad de las legis actionis las hizo odiosas, por cuyo motivo la Ley Aebutia (año 130 a. C) y las dos leyes Julias (año 17 a. C) 26 $^{26}$ las abolieron, introduciendo en su lugar el procedimiento «per formulas $»^{27}$ que se diferenciaba del antiguo procedimiento de las legis actionis en que las partes contendientes, en vez de realizar determinados actos solemnes y simbólicos y

drid. 1987 pág. 139 -141 que: «la ley de las XII Tablas vino a recoger dos corrientes o tendencias que se estaban produciendo en la sociedad romana del $\mathrm{S} \mathrm{V} \mathrm{a.} \mathrm{C} \mathrm{de} \mathrm{carác-}$ ter materialista y de carácter individualista respectivamente». Expresión de dicha tendencia individualista es, sigue diciendo, «la Tabla V.5 al conceder la actio familiae erciscundae como medio judicial de división del patrimonio hereditario venía a colocar al individuo, una vez más, en posición superior respecto de la familia a la que pertenecía pues quedaba legitimado para exigir, en cualquier momento, su porción hereditaria con la consiguiente disgregación de la unidad comunitaria».

${ }^{24}$ Vid. FERNÁNDEZ DE BUJÁN, A. Jurisdicción y Arbitraje..., Op. cit. pág. 88.

${ }^{25}$ Vid. FERNÁNDEZ DE BUJÁN, A. Jurisdicción y Arbitraje..., Op. cit. pág. 89.

${ }^{26}$ Señala FERNÁNDEZ DE BUJÁN, A. Jurisdicción y Arbitraje..., Op. cit. pág. 108 que en la doctrina romanista existen dos teorías: la que sostiene que la Lex Aebutia introdujo la posibilidad de optar voluntariamente entre tramitar la controversia por las acciones de ley o por el procedimiento escrito formulario por lo que las leyes Julias simplemente derogaron formalmente el procedimiento verbal de las legis actiones y establecieron la obligatoriedad del procedimiento formulario, y otra teoría, que ha ganado adeptos en los últimos decenios, según la cual la lex Aebutia habría establecido el procedimiento per formulas para la legis actio per condictionem y que fue" la Lex Iulia de Iudiciorum privatorum romanorum la que habría extendido el nuevo proceso escrito a la tramitación del resto de las acciones de ley al propio tiempo que procedía a la derogación formal de estas».

${ }^{27}$ Gayo Instituciones 4,30: «Sed istae omnes legis actiones paulatim in odium uenerunt. Namque ex nimia subtilitate veterum qui tunc iura condiderunt eo res perducta est, ut uel qui minimum errasset litem perderet. Itaque per legem Aebutiam et duas Julias sublatae sunt istae legis actiones effectumque est, ut per concepta verba, id est per formulas litigemus». 
pronunciar determinadas palabras sacramentales, presentaban al magistrado un breve escrito (fórmula). Así, ante el Magistrado, dotado de imperium, se ventila el pleito en la primera fase (procedimiento In Iure) y la función del magistrado «se limita aquí a aceptar o rechazar la fórmula aportada por las partes autorizando o no -actionem dare, actionem denegare- la entrada en el iudicium ${ }^{28}$.

Si el Magistrado autoriza la entrada en el iudicium entonces hace suyo el breve escrito presentado por las partes (la fórmula) y pasa dicho escrito, que fija la relación jurídica procesal, al juez para que le sirva de información sobre la materia objeto del litigio. Se entra, así, en la segunda fase (procedimiento apud iudicem) y el iudicium se sustanciará «ante el iudex o los iudices, simples particulares, árbitros o jueces populares» y terminará en la sentencia. La función juzgadora no se basa en el imperium del que estos no están asistidos (y que corresponde al Magistrado) sino -dice IGLESIAS SANTOS ${ }^{29}$ "en el officium que tiene su apoyo en el juramento hecho al ser nombrado y por el que prometen fallar de acuerdo con las normas del derecho positivo ${ }^{30}$.

El procedimiento formulario se mantuvo en vigor durante toda la época clásica y no fue formalmente derogado hasta una Constitución de Constantino y Constante de 342 d. C. pero con el tiempo, durante el Imperio, se fue imponiendo la práctica procesal de que los litigios se resolvieran en una sola vía -extra ordinem- ante el Magistrado lo que terminó con la división del proceso en las dos fases, in iure y apud iudicem, que vimos. "El juez, dice IGLESIAS SANTOS ${ }^{31}$-es ahora funcionario público, órgano de la administración del Estado y ante él se sustancia el pleito en un solo momento procesal».

Además del «arbitraje legal» (contenido principalmente en la Ley de las XII Tablas ${ }^{32}$ ) «la institución del arbitraje tiene un campo de actuación más natural, como técnica de resolución de conflictos basado en la autonomía de la voluntad de las partes y que recibiría la denominación de arbitraje compromisario», que se conformó como un arbitraje de equidad y que tenía un marcado carácter contractual y cuya regulación se contiene básicamente en el Digesto 4.8.

${ }^{28}$ Vid. IGLESIAS SANTOS, J. Derecho Romano... Op. cit., pág. 206.

${ }^{29}$ Ibidem.

${ }^{30}$ Vid. IGLESIAS SANTOS, J. Derecho Romano... Op. cit., pág. 215.

${ }^{31}$ Vid. IGLESIAS SANTOS, J. Derecho Romano...Op. cit., pág. 231.

${ }^{32}$ A dicha Ley habría los casos a los que se hace referencia en Ciceron pro Roscio 4.11 que señala que en caso de reclamación de una deuda indeterminada o de un incertum se procedería al nombramiento de un árbitro [ «... aliud est iudicium aliud est arbitrium. Iudicium est pecuniae certae, arbitrium incertae...»]. 
Como señala DE CASTRO y BRAVO ${ }^{33}$ la construcción jurídica del arbitraje en Derecho Romano «consta de dos convenios. Por el primero, aquellas partes que entre sí tienen una controversia o litigio [...] se harán mutuas promesas («cum-promisso facto») para confiar su decisión a una tercera persona (arbiter)» pero, puesto que los particulares no podían conferir a otra persona funciones judiciales ni otorgar a su decisión la eficacia de una sentencia, «esta dificultad se salva ingeniosamente mediante la estipulación de una pena pecuniaria que habría de pagar la parte que no cumpliera lo ordenado por el árbitro a la parte que estaba conforme con la Sentencia arbitral». El segundo convenio obliga al árbitro respecto de las partes una vez que haya aceptado el arbitraje («arbitrium recipere») a ejercer el oficio de árbitro pudiendo el Pretor, para el caso de que no cumpla su cometido, llegar a imponerle una multa (Paulo, D. 4. 8. 32) ${ }^{34}$.

El Derecho Justinianeo contiene una regulación detallada y acabada de la institución arbitral comenzando el Digesto (Paulo, D. 4.8.1) por señalar que «redúcese el compromiso a una semejanza de juicio y tiene por objeto terminar los pleitos» (Paulus, Compromissum ad similitudinem iudiciorum redigitur et ad finiendas lites pertinet). El arbitraje era de libre aceptación pero, una vez aceptado, debía el árbitro desempeñar el encargo ${ }^{35}$ siendo un cargo personalísimo ${ }^{36}$. No podían

${ }^{33}$ Vid. DE CASTRO Y BRAVO, F. El arbitraje.... Op. cit., págs. 626 y 627.

${ }^{34}$ En igual sentido FERNÁNDEZ DE BUJÁN, A. Jurisdicción y Arbitraje..., Op. cit. pág. 222 y ss: «Formalizado el compromiso, la aceptación del árbitro dirigida a conocer y decidir la controversia se sanciona por el Pretor desde finales del siglo II a. C. mediante un edictum de receptis, de modo que si bien el pretor no puede obligarle a dictar sentencia, sí puede forzarle indirectamente a ello a través de la vía de la multa o el embargo".

${ }^{35}$ Ulpiano, D.4.8.3.1: «No obstante, que el pretor no obligue a nadie a aceptar la facultad arbitral porque esta es cosa libre e independiente y puesta fuera de la obligación de su jurisdicción, sin embargo luego que una vez hubiere alguien aceptado el arbitraje juzga el Pretor que la cosa corresponde a su cuidado y solicitud, no tanto porque procure que los pleitos se terminen sino porque no hayan de ser defraudados los que le eligieron como hombre bueno por juez árbitro entre ellos.[...]» [Tametsi neminem praetor cogat arbitrium recipere, quoniam haec res libera et soluta est et extra necessitatem iurisdictionis posita, attamen ubi semel quis in se receperit arbitrium, ad curam et sollicitudinem suam hanc rem pertinere praetor putat: non tantum quod studeret lites finiri, verum quoniam non deberent decipi, qui eum quasi virum bonum disceptatorem inter se elegerunt...]. Todas las traducciones del Digesto contenidas en este trabajo se han recogido de "Cuerpo del Derecho Civil Romano, Instituta-Digesto.» Traductor GARCÍA DEL CORRAL, I. Ed. Jaime Molinas, Barcelona, 1889.

${ }^{36}$ Ulpiano, D.4.8.45: «La facultad arbitral expresada a favor de una persona en los compromisos no sale de aquella persona» [In compromissis arbitrium personae insertum personam non egreditur]. 
ser árbitros los jueces sobre los asuntos que les correspondía juzgar ${ }^{37}$, los que tuvieran enemistad con alguna de las partes ${ }^{38}$, los menores de 20 años $^{39}$, los esclavos (Ulpiano, D 4.8.7) los pupilos, los locos, los sordos ni los mudos (Ulpiano, D 4.8.9.1). También se prohibía que alguien fuera árbitro sobre asuntos propios ${ }^{40}$. No podían ser objeto de arbitraje las cuestiones relativas a la libertad o sobre una acción popular $^{41}$, sobre asuntos futuros ${ }^{42}$, sobre algún delito infamante o sobre

${ }^{37}$ Ulpiano, D.4.8.9.2: «Si alguno fuese Juez prohíbesele por Ley Julia que admita la facultad arbitral sobre el negocio de que es juez o que mande que a su favor se contraiga el compromiso" [Si quis iudex sit, arbitrium recipere eius rei, de qua iudex est, inve se compromitti iubere prohibetur lege iulia].

${ }^{38}$ Paulo, D.4.8.32.14: «Cuando uno de los árbitros hubiese aparecido siendo manifiestamente enemigo por otras causas y reconvenido también con las pruebas para que no pronunciase sentencia hubiese perseverado no obstante en pronunciarla sin apremiarle nadie el Emperador Antonino proveyó al libelo de uno que se querelló de esto que podía usar de la excepción de dolo malo. Y el mismo, siendo consultado por un juez ante quien se pedía la pena, respondió por rescripto que aun cuando no puede apelarse habrá de obstar en la petición de la pena la excepción de dolo malo. Así pues, por esta excepción hay cierta especie de apelación, como quiera que se licito revocar la sentencia del árbitro». [Cum quidam arbiter ex aliis causis inimicus manifeste apparuisset, testationibus etiam conventus, ne sententiam diceret, nihilo minus nullo cogente dicere perseverasset, libello cuiusdam id querentis imperator antoninus subscripsit posse eum uti doli mali exceptione et idem, cum a iudice consuleretur, apud quem poena petebatur, rescripsit, etiamsi appellari non potest, doli mali exceptionem in poenae petitione obstaturam. per hanc ergo exceptionem quaedam appellandi species est, cum liceat retractare de sententia arbitri]

${ }^{39}$ Calístrato, D.4.8.41: «Estando prevenido por la Ley Julia que el menor de veinte años no sea obligado a Juzgar, a nadie es licito elegir como juez compromisario al menor de veinte años[...]» [Cum lege iulia cautum sit, ne minor viginti annis iudicare cogatur, nemini licere minorem viginti annis compromissarium iudicem eligere...].

${ }_{40}$ Marciano, D.4.8.51: «Si alguno fue nombrado árbitro en negocio propio no puede pronunciar sentencia porque él mismo se mandaría hacer o se prohibiría pedir; y nadie puede mandarse ni prohibirse a sí mismo». [Si de re sua quis arbiter factus sit, sententiam dicere non potest, quia se facere iubeat aut petere prohibeat: neque autem imperare sibi neque se prohibere quisquam potest].

${ }^{41}$ Paulo, D.4.8.32.7: «Formalizado compromiso sobre cuestión relativa a la libertad con razón no será compelido el árbitro a pronunciar sentencia porque es privilegio de los que han obtenido la libertad que haya de tener jueces superiores. Lo mismo ha de decirse si la cuestión fuera sobre la condición de ingenuo o la de libertino y si se dijera que se debe la libertad por razón de un fideicomiso. Lo mismo se ha de decir respecto de una acción popular». [De liberali causa compromisso facto recte non compelletur arbiter sententiam dicere, quia favor libertatis est, ut maiores iudices habere debeat. eadem dicenda sunt, sive de ingenuitate sive de libertinitate quaestio sit et si ex fideicommissi causa libertas deberi dicatur. idem dicendum est in populari actione].

${ }^{42}$ Paulo, D.4.8.46: «El árbitro puede juzgar de aquellas cosas, cuentas y controversias que desde un principio hubiesen existido entre los que otorgaron el compromiso, no de aquellas que después sobrevinieron". [De his rebus et rationibus et controversiis iudicare arbiter potest, quae ab initio fuissent inter eos qui compromiserunt, non quae postea supervenerunt]. 
la cosa respecto a la que haya establecida acción pública ${ }^{43}$ y se insistía en que los árbitros sólo podían resolver sobre las cuestiones que las partes les hubieran sometido ${ }^{44}$.

Una vez aceptado el cargo, el árbitro podía excusarse de su desempeño cuando hubiera sido difamado por los litigantes o hubiera sobrevenido una enemistad capital con uno o todas las partes, por edad, enfermedad que sobrevino después, ocupación de negocios propios o por alcanzar algún cargo público ${ }^{45}$, por hacerse sacerdo$\mathrm{te}^{46}$, por tener un juicio si no pudiera prorrogarse el día del compro-

${ }^{43}$ Paulo, D.4.8.32.6: «Escribe Juliano sin hacer distinción alguna que si por error se recurrió a un árbitro sobre algún delito famoso o sobre cosa respecto a la que haya establecida acción pública por ejemplo sobre adulterios, sicarios y otras semejantes el Pretor debe vedar que se pronuncie sentencia así como que se dé cumplimiento a la dictada». [Iulianus indistincte scribit: si per errorem de famoso delicto ad arbitrum itum est, vel de ea re, de qua publicum iudicium sit constitutum, veluti de adulteriis sicariis et similibus, vetare debet praetor sententiam dicere nec dare dictae exsecutionem].

${ }^{44}$ Paulo, D.4.8.32.15: «Ha de saberse por los que ejercen el cargo de árbitro que todos sus actos han de emanar del mismo compromiso; porque a ninguno le será licita otra cosa más que la que allí se expresó que pueda hacer. Así pues, no podrá el árbitro resolver cualquier cosa sino respecto de aquella sobre la que versa el compromiso y hasta cuanto alcanza el compromiso». [De officio arbitri tractantibus sciendum est omnem tractatum ex ipso compromisso sumendum: nec enim aliud illi licebit, quam quod ibi ut efficere possit cautum est: non ergo quod libet statuere arbiter poterit nec in qua re libet nisi de qua re compromissum est et quatenus compromissum est] y Paulo, D.4.8.32.21:«El árbitro no puede hacer nada que esté fuera del compromiso [...]» [Arbiter nihil extra compromissum facere potest...].

${ }^{45}$ Ulpiano, D.4.8.15: «Mas aunque terminantemente diga el Pretor que obligará al árbitro a dictar sentencia sin embargo a veces debe tener en cuenta la razón de aquel y admitir su excusa con conocimiento de causa, por ejemplo si hubiera sido infamado por los litigantes o si hubieren sobrevenido capitales enemistades entre él y los litigantes, o uno de los litigantes o si la edad o una enfermedad que sobrevino después o la ocupación de negocios propios o una urgente marcha o algún cargo de la República le dispensaran de su cometido; y así lo dice Labeón». [Licet autem praetor destricte edicat sententiam se arbitrum dicere coacturum, attamen interdum rationem eius habere debet et excusationem recipere causa cognita: ut puta si fuerit infamatus a litigatoribus, aut si inimicitiae capitales inter eum et litigatores aut alterum ex litigatoribus intercesserint, aut si aetas aut valetudo quae postea contigit id ei munus remittat, aut occupatio negotiorum propriorum vel profectio urguens aut munus aliquod rei publicae: et ita labeo].

${ }^{46}$ Paulo, D.4.8.32.4: «Veremos si haciéndose sacerdote será el árbitro obligado a pronunciar sentencia; porque esto se dispensa no tanto en gracia al honor de las personas sino también a la majestad de Dios a cuyas cosas sagradas conviene que los sacerdotes se dediquen. Pero si después aceptó el arbitraje también este debe, de todos modos, pronunciar sentencia». [Sacerdotio obveniente videbimus an cogatur arbiter sententiam dicere: id enim non tantum honori personarum, sed et maiestati dei indulgetur, cuius sacris vacare sacerdotes oportet. ceterum si postea suscepit, iste quoque omnimodo sententiam ferre debet]. 
miso ${ }^{47} \mathrm{y}$, en general, si le sobreviniese cualquier otro impedimento después de aceptado el arbitraje y salvo que pudiera prorrogarse ${ }^{48}$. El árbitro es libre para dictar sentencia ${ }^{49}$, pero una vez que la dicta no puede corregirla ${ }^{50}$.

En todo caso, como señala el Dig 4.8.21.7, «los litigantes no deben obedecer si el árbitro hubiese mandado alguna cosa que no fuera honesta». Si alguna de las partes no cumple lo acordado en la sentencia arbitral incurre en la pena prevista en la estipulación ${ }^{51}$. Igualmente, incurre en dicha pena el litigante que habiendo sometido el litigio a arbitraje lo plantease ante el Juez continuándose el pleito por sus trámites ante el Juez ${ }^{52}$.

${ }^{47}$ Paulo, D.4.8.16.1: «El árbitro debe ser excusado del compromiso por razón del juicio propio que público o privado tiene pero solamente si no puede prorrogarse el día del compromiso [...]» [Arbiter iudicii sui nomine, quod publicum aut privatum habet, excusatus esse debet a compromisso, utique si dies compromissi proferri non potest.].

${ }^{48}$ Paulo, D.4.8.16 pr: «Y si le sobreviniese cualquier otro impedimento después de aceptado el arbitraje. Pero en el caso de enfermedad o de otros semejantes es obligado a prorrogarlo con conocimiento de causa.»[Et si qua alia incommoditas ei post arbiterium susceptum incidat. sed in causa valetudinis similibusve causa cognita differre cogitur].

${ }^{49}$ Paulo, D.4.8.19 pr:: «Mas dice Labeon que no es de la incumbencia del Pretor cual sea la sentencia que pronuncie el árbitro con tal que pronuncie la que le parezca. Y por esto si el compromiso se hizo a favor del árbitro es esta forma para que pronuncie determinada sentencia escribe Juliano en el Libro cuarto del Digesto que es nulo el arbitraje y que no ha de ser obligado a pronunciar sentencia». [Qualem autem sententiam dicat arbiter, ad praetorem non pertinere labeo ait, dummodo dicat quod ipsi videtur. et ideo si sic fuit in arbitrium compromissum, ut certam sententiam dicat, nullum esse arbitrium, nec cogendum sententiam dicere iulianus scribit libro quarto digestorum].

${ }^{50}$ Gayo, D.4.8.20.: «Porque el árbitro, aunque hubiere errado al pronunciar, sentencia no puede corregirla.» [Quia arbiter, etsi erraverit in sententia dicenda, corrigere eam non potest].

${ }^{51}$ Ulpiano, D.4.8.2: «Se halla establecido que del compromiso no nace excepción sino petición de la pena». [Ex compromisso placet exceptionem non nasci, sed poenae petitionem].

${ }^{52}$ Paulo, D.4.8.30.: «Si alguno dedujese en juicio el asunto sobre el cual se hubiese otorgado el compromiso dicen algunos que no interviene el Pretor para obligar al árbitro a pronunciar sentencia porque ya no puede haber pena, cual si se ha disuelto el compromiso. Pero si esto fuese así resultará que estaría en la facultad del que se arrepintiera de haberse comprometido eludir el compromiso. Por consiguiente, se le habrá de imponer la pena debiéndose continuar el pleito por sus trámites ante el juez». [Si quis rem, de qua compromissum sit, in iudicium deducat, quidam dicunt praetorem non intervenire ad cogendum arbitrum sententiam dicere, quia iam poena non potest esse, atque si solutum est compromissum. sed si hoc optinuerit, futurum est, ut in potestate eius, quem paenitet compromisisse, sit compromissum eludere. ergo adversus eum poena committenda est lite apud iudicem suo ordine peragenda.]. 
Como señala FERNÁNDEZ DE BUJÁN, A. ${ }^{53}$, «el laudo arbitral no producía efecto de cosa juzgada, ni tenía por sí carácter ejecutivo, salvo en un período de tiempo de nueve años, comprendido entre el 529, Constitución de Justiniano, C. J. 2.55.3, y la fecha de promulgación de la Novela 82.11, y para aquellos supuestos en los que las partes hubieran elegido el árbitro bajo juramento y éste se hubiese comprometido también bajo juramento a dictar una sentencia justa».

A modo de conclusión, para contextualizar la deuda histórica de la NLAB con el derecho romano, debemos citar a FERNÁNDEZ DE BUJÁN, A. ${ }^{54}$, quien señala que «Con carácter general, cabe subrayar que en el Derecho romano hay un mayor grado de reconocimiento de la autonomía de la voluntad de las partes en la configuración del arbitraje, así como un mayor reconocimiento de la discrecionalidad en la actuación arbitral que la existente en el arbitraje moderno ${ }^{55}$, que se caracteriza, en esencia, por el carácter imperativo de muchas de las normas aplicables al arbitraje, que quedan fuera, por tanto, de la disponibilidad de las partes, en aras de una mayor seguridad jurídica y del reforzamiento de las garantías de los intervinientes ${ }^{56} »$.

\subsubsection{Marco de referencia de la responsabilidad de los árbitros desde la óptica del Derecho Positivo Contemporáneo Español}

Nuestra mejor jurisprudencia ha dejado claro que el arbitraje sólo llega hasta donde alcanza la libertad, que es su fundamento y motor. El elemento subjetivo, conectado con el objetivo, pone el énfasis en la diferente configuración del Juez, titular de la potestad de juzgar y hacer ejecutar lo juzgado que emana del pueblo (art. $117 \mathrm{CE}$ ), revestido, por tanto, de imperium, y del árbitro, desprovisto de tal carisma o

${ }^{53}$ Vid. FERNÁNDEZ DE BUJÁN, A. Jurisdicción y Arbitraje... Op. cit., pág. 225.

${ }^{54}$ Ibidem.

${ }^{55}$ En relación con la fundamentación del arbitraje en la autonomía de la voluntad de las partes, y su vinculación con la libertad como valor superior del ordenamiento, Vid. STC 176/1996, de 11 de noviembre (BOE de 17 de diciembre): «Tal planteamiento, sin embargo, no puede ser compartido, ya que supondría tanto como privar al arbitraje, cuya licitud constitucional hemos declarado reiteradamente (SSTC $43 / 1988,233 / 1988,233 / 1988,15 / 1989,288 / 1993$ y 174/1995), de su función como medio heterónomo de arreglo de controversias que se fundamenta en la autonomía de la voluntad de los sujetos privados, lo que constitucionalmente le vincula con la libertad como valor superior del ordenamiento...».

${ }^{56}$ Suele ser frecuente, en todo caso, en el Derecho actual, que en determinados sectores de la actividad económica, las partes, por razones de agilidad, sencillez, brevedad, especialización y economía de medios acuerden, mediante cláusula insertada en el contrato que formalizan, la sumisión a arbitraje, en caso de conflicto en la interpretación o aplicación de las disposiciones previstas en la relación negocial. 
cualidad, cuyo mandato tiene su origen en la voluntad de los interesados, dentro de una concreta controversia. En definitiva, es un particular que ejerce una función pública sin que puedan los órganos jurisdiccionales revisar el laudo con la única excepción de haber vulnerado aquel en la solución del conflicto el orden público, entendido éste en sentido amplio como infracción de principios constitucionales, pues para que un laudo arbitral sea atentatorio contra el orden público, es preciso básicamente que vulnere los derechos y libertades fundamentales reconocidos en el capítulo II, título I de nuestra Constitución garantizados a través de lo dispuesto en términos de generalidad por el artículo 24 de la misma.

Siendo el arbitraje un «equivalente jurisdiccional», mediante el cual las partes pueden obtener los mismos objetivos que con la jurisdicción civil, esto es, la obtención de una decisión que ponga fin al conflicto con todos los efectos de la cosa juzgada, es evidente que la creación de órganos de naturaleza arbitral y el establecimiento de dicho procedimiento heterocompositivo es materia propia de la legislación procesal civil, relacionada, en cuanto a los efectos del laudo arbitral y al sistema de recursos, con la Administración de Justicia.

La naturaleza híbrida de la institución arbitral lleva incluso a cuestionar si la responsabilidad arbitral es contractual, delictual o cuasidelictual y, en esa línea, si son válidas las cláusulas de exoneración total de responsabilidad de los árbitros de las Instituciones Arbitrales permanentes. La regulación vigente sobre esta materia la encontramos en la NLAB, en su artículo 21.1, que tiene el siguiente tenor literal: «La aceptación obliga a los árbitros y, en su caso, a la institución arbitral, a cumplir fielmente el encargo, incurriendo, si no lo hicieren, en responsabilidad por los daños y perjuicios que causaren por mala fe, temeridad o dolo. En los arbitrajes encomendados a una institución, el perjudicado tendrá acción directa contra la misma, con independencia de las acciones de resarcimiento que asistan a aquélla contra los árbitros.»

\subsection{Responsabilidad de las Instituciones arbitrales permanentes}

Se trata de una responsabilidad que en la NLAB se tipifica como civil por los daños y perjuicios que cause en la gestión y administración del arbitraje cuando intervenga mala fe, temeridad o dolo (art. 21 NLAB). 
La exigencia de la responsabilidad civil a la institución arbitral supone tener en cuenta las siguientes previsiones ${ }^{57}$ :

La NLAB sólo prevé la exigencia de responsabilidad civil a la institución arbitral, pero esa previsión no excluye la posibilidad de exigir también responsabilidad penal a algún miembro de la institución arbitral.

La exigencia dual de responsabilidad afecta tanto a la institución arbitral pública como privada (ésta última asociación sin ánimo de lucro en cuyos estatutos se contemple la realización de funciones arbitrales).

La exigencia de responsabilidad a la institución arbitral posee un momento a quo indudable, que se cifra a partir del momento en que la institución arbitral acepta los servicios de gestión y administración del arbitraje.

El verdadero alcance y efectividad del artículo 21.1 NLAB sólo podrá medirse jurisprudencialmente y a través de la praxis arbitral, puesto que son múltiples las cuestiones que pueden surgir y que en el contexto de una institución arbitral suponen dos tipos de obligaciones. De un lado, la de aplicar su propio Reglamento de Arbitraje y, de otro, la de llevar a cabo la gestión y administración del arbitraje, posibilitando, en su caso, el desarrollo de la instancia arbitral con respeto a las garantías que deben aplicarse a la misma. No obstante, podemos enumerar las principales causas de responsabilidad:

- Aceptación o inadmisión del encargo arbitral.

- Ilegalidad en el nombramiento de los árbitros ${ }^{58}$.

- Formalización del Acta de inicio en la que se establece el desarrollo de la actuación arbitral y concretamente su procedimiento y el calendario de actuaciones con arreglo al Reglamento de la institución administradora del arbitraje, cuyas

${ }^{57}$ Vid. Sentencia del Tribunal Superior de Justicia de Madrid, 63/2014.

${ }^{58}$ Destacan las siguientes posibilidades: a) La designación de árbitros que en el momento de la aceptación del encargo no se hallen en el pleno ejercicio de sus derechos; b) La designación de árbitros para resolver un arbitraje de derecho que no sean abogados en ejercicio; c) La inobservancia por la institución administradora del arbitraje de sus normas reglamentarias para la designación de árbitros; d) La designación de árbitro o Colegio arbitral, por parte de las Corporaciones y Asociaciones, que coloque a una de las partes en cualquier situación de privilegio; e) La designación de árbitros sin capacidad civil suficiente; f) La designación como árbitros de personas recusables g) La designación de un número de árbitros que no sea impar o contraviniendo el Reglamento que rige el procedimiento del arbitraje institucional. 
disposiciones en ningún caso pueden vulnerar lo dispuesto por la NLAB con carácter imperativo.

- Reglamento de la institución arbitral no respetuoso con los principios de igualdad, audiencia y contradicción.

— Extralimitación por falta de arbitrabilidad.

- No actuar con neutralidad respecto de las partes, con desinterés respecto del thema decidendi, y con independencia, con ausencia de vínculos de sujeción -más allá de los que son propios de o inherentes al arbitraje institucional- que puedan poner en entredicho, fundadamente, la ecuanimidad de su proceder, y puesto que en el momento de admitir el encargo arbitral la Corporación o Asociación pueden resolver admitirlo, aunque su decisión no vincule al árbitro en el momento de su aceptación ni de laudar sobre puntos o cuestiones que, aún previstos en el convenio arbitral, no pueden ser objeto de arbitraje.

\section{TIPOS DE RESPONSABILIDADES DEL ÁRBITRO}

A nuestro juicio, los árbitros, en el desarrollo de sus funciones como tales, no solamente son susceptibles de incurrir en responsabilidad civil, sino que también se podrían depurar responsabilidades en los ámbitos penal, negocial, extracontractual, administrativo y disciplinario privado. Veamos un resumen de cada una de esas posibilidades:

\subsection{Responsabilidad penal}

El árbitro está sometido como un ciudadano más a las reglas punitivas generales del Código Penal ${ }^{59}$, aunque ello no sea óbice para que sean de aplicación los siguientes criterios:

${ }^{59}$ Siguiendo la clasificación de FERNÁNDEZ DE BUJÁN, Federico, podemos clasificar de facto como delicta los ilícitos penales en relación a su comisión por el árbitro, dado que para su descubrimiento necesitan de la acción del afecto. Vid. acusación del ilícito penal en Derecho Romano en Ética e imparcialidad del Ministerio Fiscal (coordinado por Luis Bueno Ochoa). Dykinson. Madrid. 2011, págs. 13 a 31: «Quizás pueda señalarse que la principal diferencia es que la Civitas fue consciente que debía monopolizar la facultad de juzgar cuando el acto que se enjuiciaba conlleva cómo sanción la muerte del contable. En este sentido, para los ilícitos penales públicos que se consideran crimina, debido a que él acto delictual atenta contra los intereses generales de la comunidad política, no se precisa denuncia o persecución por parte de la víctima. Para los delicta, ilícitos penales privados, debido a su menor 
- Que determinadas acciones u omisiones, dolosas o imprudentes penadas por la Ley, produzcan efectos sobre el laudo que dicte el árbitro, incluida su propia revocación. Sólo desde este punto de vista existe una cierta especialidad penal en la actividad del árbitro.

- Que determinados tipos penales aplicables específicamente a autoridades y funcionarios públicos sean también extensibles a los árbitros, como ocurre con el cohecho del artículo 422 del Código Penal y con los negocios y actividades prohibidas y el abuso en el ejercicio de funciones del artículo 440 del Código Penal.

- Que toda responsabilidad criminalmente declarada sobre el árbitro crea en éste la obligación civil de reparar por vía indemnizatoria los daños y perjuicios causados a tenor de lo establecido en los artículos 109 y 116 del Código Penal, con la extensión contenida en los artículos 110 y 113 del citado código. Es decir, la responsabilidad civil por razón del delito causado por el árbitro abarca cuántos quebrantos sufra el patrimonio del perjudicado por razón del mismo.

- La responsabilidad civil podrá ejercitarse en el mismo proceso penal o independientemente del mismo, siendo el Ministerio Fiscal quién deba aunar siempre la acción civil conjuntamente con la penal, a no ser que los perjudicados prefieran ejercitar separadamente la acción civil, tal y como establecen los artículos 110 y 112 de la Ley de Enjuiciamiento Criminal, o renunciar previamente al ejercicio de la acción civil, tal y como recogen los artículo 107 y 108 de la Ley de Enjuiciamiento Criminal.

- Finalmente, serán los jueces y tribunales, al declarar la existencia de responsabilidad civil del árbitro, quienes establecerán razonadamente en sus resoluciones las bases en que fundamenten la cuantía de los daños e indemnizaciones, pudiendo fijarlo en la propia resolución o en el momento de su ejecución, tal y como establece el artículo 115 del Código Penal.

Dentro de los delitos cometidos por el árbitro relacionado directamente con las partes del proceso arbitral, se encuentran:

- El tipo específico del llamado cohecho arbitral del artículo 422 del Código Penal.

gravedad y, sobre todo, a la menor incidencia en el cuerpo social, su persecución y sanción queda a instancia de los afectados. Ello implica que en los delicta, el proceso que contra el presunto culpable se inicia a través de la interposición de una acción penal, que a pesar de su denominación provoca la incoación de un procedimiento que se sitúa en la normativa que regula el Derecho procesal civil.» 
- Los tipos genéricos de amenazas de los artículos 169 y 171 del Código Penal y coacciones del artículo 172 del Código Penal, y por utilizar violencia o intimidación a las partes o testigos del proceso arbitral, el del artículo 464 del Código Penal.

- Los genéricos de descubrimiento y revelación de datos de los artículos 197.4 y 200 del Código Penal, y de incumplimiento de la obligación de sigilo o reserva del artículo 199.2 del Código Penal

Con respecto a las infracciones del árbitro que se relacionan con el objeto de la controversia o con los bienes o cosas que le afectan, podemos identificar dos tipos diferentes:

A) El específico de las actividades prohibidas y abuso en el ejercicio de la función arbitral del artículo 440 del Código Penal, que lleva aparejada la pena prevista en este precepto. En este caso resulta difícil incardinar la conducta del árbitro en alguno de los motivos del artículo 510 de la Ley de Enjuiciamiento Civil, que como hemos visto pudieran dar lugar a la revisión del laudo firme, a no ser que se instara la revisión a través de la maquinación fraudulenta prevista en el apartado cuarto del artículo 510 de la Ley de Enjuiciamiento Civil, circunstancia que nosotros no compartimos.

B) El genérico de falsificación de documento público cometido por el árbitro de los artículos 392 y 393 del Código Penal admite, conforme al artículo 390 Código Penal y por la remisión que a este precepto hace el artículo 392 del Código Penal, una triple variante punitiva.

En el arbitraje ad hoc con un árbitro único, éste es el único responsable penal según el tipo de delito cometido y, por tanto, será también el único responsable civil de acuerdo con el artículo 116.1 del Código Penal. En el caso de un Colegio Arbitral, cabe distinguir tres supuestos diferentes:

Que todos los árbitros se hayan manifestado de acuerdo y todos ellos de consuno hayan cometido la infracción penal, lo que significa que son todos responsables criminalmente, conforme al delito cometido y, civilmente, la responsabilidad será solidaria frente al perjudicado. En caso de que se haga efectivo por uno de los árbitros el pago completo derivado de la responsabilidad civil solidaria queda a salvo su derecho de repetición contra el resto de los árbitros por las cuotas correspondientes a cada uno de ellos, tal y como establece el artículo 116.2 en su párrafo final.

Que alguno de los árbitros del Colegio Arbitral haya salvado su voto por discrepancia manifiesta con la mayoría sobre el contenido final del 
laudo, pero no haya denunciado los hechos al perjudicado o a la autoridad competente o ni siquiera haya comunicado esos hechos presuntamente punitivos al Ministerio Fiscal, en cuyo caso es posible que no le afecte la responsabilidad penal pero sí la civil, de la que responderá solidariamente con el resto de los árbitros, a juicio de MERINO MERCHÁN, que nosotros compartimos.

Que el árbitro disidente denuncie ante la autoridad judicial competente el hecho punible o lo ponga de manifiesto al perjudicado o al Ministerio Fiscal, separándose expresamente de la conducta adoptada por el resto del Colegio Arbitral. En este caso, el árbitro disidente no es responsable ni criminal ni civilmente.

Con respecto al Arbitraje Administrado se puede reproducir el mismo esquema, pero con el añadido de que la persona jurídica que encarna y da forma a la institución arbitral, ya sea una corporación o una asociación, a tenor de lo previsto en el artículo 14 NLAB, es responsable civil solidaria derivada o consecuente de la responsabilidad criminal del árbitro, a tenor de lo establecido en el artículo 21.1 NLAB.

\subsection{Responsabilidad disciplinaria privada}

Los árbitros están exentos de responsabilidad disciplinaria, strictu sensu, teniendo el carácter no funcionarial del árbitro en este aspecto una de sus manifestaciones más claras. Cabe, sin embargo, pensar en una responsabilidad paradisciplinaria o disciplinaria privada, en relación con el arbitraje institucional o corporativo, en cuanto que las personas designadas como árbitros pueden estar sometidas, en virtud de su vinculación contractual con la entidad, a determinados comportamientos, cuya exigibilidad dependerá del ámbito legítimo que marque en su desarrollo el principio de autonomía de la voluntad. De este modo, definimos por responsabilidad disciplinaria la que es exigida al árbitro por la Institución Arbitral permanente de la que es miembro, como consecuencia de las infracciones cometidas en el ejercicio de sus funciones arbitrales, siempre que dichas infracciones estén previamente tipificadas en los estatutos de la institución o en el correspondiente Código de conducta ética profesional al que se encuentra vinculado.

Los estatutos de este tipo de organizaciones estables que tienen como finalidad institucional, bajo la base consensual a la que se refiere el Tribunal Constitucional, administrar arbitrajes, son normas primarias que dan origen al nacimiento de las mismas, junto con la correspondiente acta fundacional y por las que se configuran su vida 
interna y su ámbito formal y material de actuación, dotándose a su vez de un reglamento conforme al cual ejercerán su funciones típicamente conciliatorias y arbitrales, como señala el artículo 14.2 NLAB. Esto es, en este conjunto de normas se regularán desde el modo de designación de los árbitros, incluido su régimen de abstención y recusación, incidentes, procedimiento contradictorio, hasta la terminación normal o anormal del proceso arbitral y todo ello sin hablar del régimen de los órganos de dirección de estos centros arbitrales. En los estatutos no pueden faltar los requisitos y modalidades para la admisión y baja, sanciones, separación de los árbitros, según impone el artículo 7.1 LO 1/2002.

Las entidades que funcionan bajo régimen estatutario no crean reglas objetivas de Derecho obligatorias para terceros, sino que su mundo organizativo y expansivo empieza y termina en el ámbito de sus propias reglas internas, por lo que si el árbitro desea ser tal, debe aceptar y cumplir los pactos y pautas de la organización que le imponga la asociación a la que quiere adherirse. No obstante, no existe una libertad absoluta a la hora de fijar las pautas bajo las que debe concebirse el Estatuto disciplinario del árbitro, sino que se deben cumplir necesariamente las dos siguientes:

A) Garantizar la seguridad jurídica del régimen sancionador interno.

B) Garantizar el control jurisdiccional sobre los actos y acuerdos sancionadores que se adopten.

Las garantías que aseguran un régimen sancionador interno y qué hacen que el mismo sea conforme con la Constitución y el resto del ordenamiento jurídico son las siguientes:

1. Tipificación de los ilícitos de arbitrales mediante una graduación de los mismos atendiendo a criterios de gravedad, con las correspondientes sanciones.

2. Compatibilidad de la responsabilidad disciplinaria con la responsabilidad penal del árbitro.

3. Establecimiento de un procedimiento disciplinario con las debidas garantías para el árbitro.

El régimen general de garantías en el que se enmarca la responsabilidad disciplinaria debe cerrarse con el control jurisdiccional sobre el acuerdo sancionatorio y a este respecto al artículo 40 LO 1/2002, 
aplicable a las Asociaciones arbitrales, como defiende MERINO MERCHÁN ${ }^{60}$ y nosotros compartimos, dispone que: "1. El orden jurisdiccional civil será competente, en los términos establecidos en la Ley Orgánica del Poder Judicial, en relación a las pretensiones derivadas del tráfico jurídico privado de las asociaciones, y de su funcionamiento interno. 2. Los acuerdos y actuaciones de las asociaciones podrán ser impugnadas por cualquier asociado o persona que acredite un interés legítimo, si los estimase contrarios al orden jurídico, por los trámites del juicio que corresponda. 3. Los asociados podrán impugnar los acuerdos y actuaciones de la asociación que estimen contrarios a estatutos dentro del plazo de 40 días, a partir de la fecha de adopción de los mismos, instando su rectificación o anulación y la suspensión preventiva en su caso, o acumulando ambas por los trámite establecidos en la Ley de Enjuiciamiento Civil».

\subsection{Responsabilidad extracontractual}

GARCÍA GARRIDO ${ }^{61}$ señala que «En relación con los efectos indirectos del contrato, la doctrina y la jurisprudencia han construido los conceptos de oponibilidad e inoponibilidad. Mientras el primero se refiere al aspecto positivo de que el contrato sea oponible a los terceros aunque no hayan participado en el contrato; el segundo destaca el aspecto negativo de que el contrato no puede oponerse a quienes no intervienen concediendo a los terceros la facultad de oponerse a las consecuencias que puede tener para ellos el convenio. La doctrina tradicional ha venido admitiendo que el principio general es el de la oponibilidad del contrato frente a terceros y la inoponibilidad es la regla excepcional que debe ser explícitamente admitida por la ley. Quizás esta sea una regla parcial que es consecuencia de la influencia de la tradición sobre los derechos reales. En general, se admite que el acto jurídico puede ser oponible cuando es conocido por los terceros afectados o existe una presunción del conocimiento del acto, como sucede cuando el acto está inscrito en un registro público».

El artículo 21.1 NLAB no reduce su ámbito a las partes del proceso arbitral, a las que no menciona, sino que utiliza en el segundo inciso el concepto genérico de perjudicado, que tiene una connotación

${ }^{60} \mathrm{Vid}$. MERINO MERCHÁN, José FERNANDO: Estatuto y Responsabilidad del Árbitro. Ley 60/2003. Editorial Thomson Aranzadi.

${ }^{61}$ Vid. GARCÍA GARRIDO, Manuel Jesús: Los efectos del contrato en relación con terceros: la experiencia Ibérica. Publicado en Gli Effetti del contrato nei confronti dei terzi nella prospecttiva storico-comparatistica. Roma. 1999. 
amplísima respecto de las personas o entidades que pueden quedar afectadas por la conducta o la actividad del árbitro. En efecto, no son las partes, sino que bajo determinadas condiciones terceros ajenos al procedimiento arbitral pueden resultar perjudicados por los actos arbitrales.

Se estará en presencia de la responsabilidad extracontractual o aquiliana a que se refiere el artículo 1.902 del Código Civil siempre que concurran los siguientes requisitos:

- Existencia de una conducta que pueda ser lícita o ilícita. El primer caso ocurre cuando el árbitro no realiza acto antijurídico alguno, pero resulta dañado un tercero y /o ocasionalmente alguna de las partes, que no tienen por qué soportar el perjuicio sufrido sobre sus bienes, derechos o intereses. El segundo caso tiene lugar cuando la acción u omisión del árbitro causante del año daño sea antijurídica, al infringirse manifiestamente lo dispuesto en la Ley.

- Producción de un daño que recae sobre bienes, derechos o intereses del perjudicado y que debe ser efectivo y real y no por tanto simples expectativas. Debe ser evaluable económicamente y cuantificable en relación a un tipo de valor o moneda de curso legal y, por tanto, debe poder concretarse en numerario e individualizado con relación a una persona o grupos de personas, es decir, es precisa la identificación del perjudicado.

- Concurrencia de una relación de causalidad entre la conducta del árbitro y el daño causado. La conducta del árbitro ha de ser presupuesto habilitante inexcusable de la causación del daño infligido al perjudicado. Este nexo de causalidad, que ha de ser acreditado por quién reclama los daños sufridos, queda muchas veces al arbitrio judicial. La relación causal puede quedar eliminada o limitada en casos especiales, como son los siguientes:

La responsabilidad objetiva desaparecen en el caso de que concurra fuerza mayor.

La propia culpa del perjudicado es otro factor externo, no natural cómo puede ser la fuerza mayor sino humano, que puede interrumpir la relación causal. En este caso hay que distinguir dos supuestos diferentes: Si concurre exclusivamente la culpa del perjudicado, la responsable del árbitro sencillamente no existe; si concurre culpa del perjudicado y del árbitro y ambos desembocan en el resultado dañoso, la doctrina y la jurisprudencia entienden que la obligación de indemnizar del agente, -en este caso del árbitro-, debe verse disminuida al concurrir la culpa del perjudicado que la reclama, con fundamento en el artículo 1.108 del Código Civil, que faculta a los tribunales para moderar la responsabilidad procedente de la culpa determinados supuestos. 
Finalmente, el nexo también se interrumpe con la consiguiente irresponsabilidad, en su caso del árbitro, en los supuestos de intervención de tercero dolosa o culposamente, siempre que no venga determinada tal intervención por la del árbitro.

La jurisprudencia ha evolucionado a partir de las tradicionales doctrinas sobre la causalidad hacia la actual concepción del nexo como un juicio de imputación que, si bien parte de la existencia de una causalidad física ${ }^{62}$, corrige sus excesos a través de la doctrina de la imputación objetiva y se entiende que cada actividad que baste por sí para causar un daño, lo ha causado en la medida correspondiente a tal probabilidad.

La responsabilidad extracontractual de los árbitros y/o de la Corporación ha de contener una previa imputación culposa o negligente, es decir, los posibles perjuicios generados deben ser debidos a una actuación ilícita a título de culpa del dañador. No basta acreditar el nexo causal entre el perjuicio denunciado y el presunto ilícito para generar responsabilidad que se califica como de «antijuricidad dañina intencional».

El encargo en que consiste la función arbitral, definida por la Ley y en cuya ejecución han de observarse pautas y deberes que participan de la materia de orden público, presenta analogías o se aproxima a la función jurisdiccional sin dejar de advertir sustanciales diferencias, si bien procede aplicar la jurisprudencia sobre responsabilidad civil judicial a esta materia; debiéndose ser calificada la conducta del árbitro o de la Corporación como de evidente para que sea cohonestable con la voluntad o la ignorancia manifiesta; debiendo ser la responsabilidad por culpa imputable a los árbitros patente, manifiesta y apreciable por cualquiera, de tal modo que la conducta negligente debe ser calificada de grave ${ }^{63}$.

\subsection{Responsabilidad administrativa}

El árbitro maneja hechos y datos personales que pueden afectar a derechos fundamentales, especialmente al honor e intimidad personal y familiar de las partes en el proceso arbitral o de terceros. Y sobre

${ }^{62}$ De ahí que puede considerarse que la actual concepción se asienta sobre la vieja doctrina de la equivalencia de las condiciones.

${ }^{63}$ Vid. Sentencia n. ${ }^{\circ}$ 25/2013 de la Audiencia Provincial de Barcelona (sección 15. ${ }^{\text {a) }}$, de 24 de enero de 2013 y Sentencia n. ${ }^{\circ}$ 25/2007 de la Audiencia Provincial de Barcelona (sección 17. ${ }^{\mathrm{a}}$ ), de 12 de enero de 2007. 
los que el árbitro tiene un deber específico de protección. En ocasiones también pueden suministrársele al árbitro datos confidenciales de orden profesional o empresarial, de difusión no autorizada o al menos restringida.

Los interesados a los que se soliciten datos personales deben ser previamente informados de modo expreso, preciso e inequívoco:

A) De la existencia del fichero tratamiento de los datos y de la finalidad y destino de la información, tal y como indica el artículo 25.1. a) LOPD.

B) Del derecho de acceso, rectificación y cancelación de los datos, tal y como indica el artículo 5.1.d) LOPD

C) De la identidad y dirección del responsable del tratamiento de los datos, según señala el artículo 5.1.e) LOPD.

D) E igualmente de cualquier uso de esos datos que siempre requerirá el consentimiento de la parte afectada, tal y como señala el artículo 6.1 LOPD.

Lo anterior no obsta para que las instituciones arbitrales permanentes puedan crear ficheros que contengan datos de las personas que hayan intervenido cómo interesados en actuaciones arbitrales, incluso la de sus propios árbitros, pero siempre que se respeten las garantías expuestas, debiendo adoptar las medidas de índole técnica y organizativa que garanticen esa seguridad, en evitación de alteraciones, pérdidas y tratamiento o acceso no autorizado, pues los árbitros y especialmente las instituciones arbitrales permanentes pueden incurrir en responsabilidades administrativas amparadas por la LOPD, siendo el órgano administrativo sancionador la Agencia Estatal de Protección de Datos, siendo recurribles las resoluciones de su Director ante la Jurisdicción Contencioso-Administrativa. Las citadas responsabilidades son absolutamente autónomas, por lo que pueden concurrir con posibles responsabilidades penales, civiles, negocionales y extracontractuales de los árbitros y de las instituciones arbitrales.

Podemos establecer las siguientes premisas:

A) Los árbitros ad hoc y los árbitros de los arbitrajes administrados están obligados a guardar la confidencialidad de la información que conozcan a través de las actuaciones arbitrales.

B) Tienen también el deber público y la obligación personal de que todos los datos de carácter personal que figuren en el expediente arbitral sean notificado a la Agencia de Protección de Datos. 
C) Asimismo, han de guardar secretos sobre los datos de carácter personal que figuran en los expedientes y ficheros en los que haya intervenido los árbitros y las instituciones permanentes de arbitraje.

D) Estas últimas deben establecer un nivel mínimo de seguridad sobre los ficheros y datos de carácter personal y profesional que haya recopilado en el ejercicio de sus funciones arbitrales.

E) Las instituciones arbitrales permanentes han de asegurar que los datos que conozcan como consecuencia de las actuaciones arbitrales no sean cedidos o utilizados por terceros sin el conocimiento del afectado

F) Las instituciones arbitrales permanentes que creen o utilicen datos de carácter personal deben instar a la Agencia de Protección de Datos para que está los inscriba en el Registro General de Protección de Datos.

La responsabilidad derivada de los puntos anteriores se articula través del Título VII de la LOPD, según que el tipo de infracción sea leve -artículo 44.2.e)-, grave -artículo 44.3.a), b), c), d), e), f), g), h), i), j), k) - o muy grave -artículo 44.4-, con las sanciones previstas en el artículo 45 y a los que hacemos remisión para evitar repeticiones.

\subsection{Responsabilidad negocial}

La responsabilidad debe considerarse contractual cuando a la preexistencia de un vínculo o relación jurídica de esa índole entre personas determinadas se une la producción, por una a la otra, de un daño que se manifiesta como la violación de aquel y, por lo tanto, cuando concurren un elemento objetivo -el daño ha de resultar del incumplimiento o deficiente cumplimiento de la reglamentación contractual, creada por las partes e integrada conforme al artículo $1258 \mathrm{CC}-$ y otro elemento subjetivo -la relación de obligación en la que se localiza el incumplimiento o deficiente cumplimiento ha de mediar, precisamente, entre quien causa el daño y quien lo recibe-. Sólo puede incurrir en responsabilidad cuando su comportamiento se aparte de la denominada lex artis ad hoc, recayendo sobre el demandante, con carga de su exclusiva incumbencia, la demostración de haberse dejado de observar por el profesional la referida lex artis. 
El profesional ha de cumplir la prestación convenida con diligencia, así como con observancia de la lex artis ad hoc o exigencias técnicas propias de la actividad desarrollada, lo que supera el tipo medio de diligencia definida por la del buen padre de familia. De modo que si la prestación no se cumplimenta de modo correcto se produce la infracción del contenido negocial como consecuencia del incumplimiento radical o el cumplimiento irregular o anómalo de la obligación que corresponde al profesional, determinante de su responsabilidad.

$\mathrm{Al}$ ser el arbitraje un todo unitario que nace de un convenio por el que se opta, en vez de acudir a la vía jurisdiccional, por un dirimente investido con un poder concreto para resolver controversia mediante laudo, al que el ordenamiento objetivamente le atribuye fuerza de cosa juzgada como si fuera una sentencia judicial firme, les cabe a las partes introducir los elementos correctores que crean convenientes respecto del comportamiento del árbitro. Entre estos elementos correctores se encuentra la facultad de establecer y ordenar el régimen de la responsabilidad del árbitro, que no excluye ni limita la responsabilidad legal configurada en el artículo 21.1 NLAB sino que la amplia a otros supuestos, como pueda ser la responsabilidad derivada de la culpa, negligencia o la simple impericia. En cuanto al tipo de culpa exigible, el pacto de responsabilidad podría determinar si se trata de la culpa lata, es decir, omisión de las precauciones más elementales, o leve, ya sea en abstracto, es decir, la que debiera emplear un buen padre de familia, o en concreto, que sería la diligencia que las personas han de tener sobre sus propios negocios.

Así, la responsabilidad arbitral por culpa puede ser modulada por las partes en el convenio arbitral o en otro momento del arbitraje antes de la aceptación del árbitro, mediante las cláusulas procedentes, que pueden lógicamente variar en su contenido. A continuación enumeramos algunas opciones:

- Imponer al árbitro la responsabilidad por culpa, incluso por culpa lata o levísima.

- Graduar la responsabilidad del árbitro según la gravedad del supuesto del supuesto de responsabilidad en que incurra.

- Exigir un seguro de responsabilidad al árbitro o tribunal arbitral por los posibles daños que causen a las partes o terceros. Esta es una obligación recogida en el segundo párrafo del artículo 21.1 NLAB pero que desgraciadamente no ha tenido desarrollo reglamentario, por lo que esa negligencia del Legislador puede ser suplida por las partes. 
- Establecer una suma indemnizatoria predeterminada por las partes que cubra a estas de los incumplimientos de los deberes y obligaciones del árbitro, es decir, lo que se denomina una cláusula penal.

La responsabilidad negocial del árbitro puede ser incorporada como lex privata en el convenio arbitral, puede ser incluida en los reglamentos de las instituciones arbitrales permanentes o incluso incorporada en un documento ad hoc al tiempo del nombramiento y aceptación del encargo arbitral. En cualquier caso, todos los detalles del pacto de responsabilidad debieran haber quedado cerrados y claramente delimitados en todos sus términos y elementos antes de la aceptación por parte del árbitro, ya que éste, antes de aceptar el encargo, debe conocer el pacto para valorar si acepta el nombramiento ${ }^{64}$.

La autonomía de la voluntad de las partes en este ámbito de la responsabilidad de los árbitros se encuentra con una barrera infranqueable, como es la responsabilidad establecida por NLAB, a través el artículo 21.1. Por lo tanto, cualquier pacto de responsabilidad, ya fuera $a d$ hoc o incluido en los estatutos de una institución arbitral permanente, que libere de responsabilidad a los árbitros cuando los mismos hubieran incurrido en su actuación en temeridad, mala fe o dolo, sería nula de pleno derecho y lógicamente su nulidad debiera ser reclamada ante la justicia ordinaria ${ }^{65}$. De este modo, defendemos que en el derecho arbitral español no cabe la inmunidad absoluta de los árbitros, que desincentivaría el buen comportamiento arbitral y la solidez de la institución, instaurando un desequilibrio indeseado entre partes, de un lado, y los árbitros y las Instituciones arbitrales, del otro.

En cuanto a las Instituciones Arbitrales permanentes, opera una responsabilidad básicamente contractual, por lo que la institución no

${ }^{64}$ Vid. Sentencia n. ${ }^{\circ}$ 307/2014 de la Audiencia Provincial de Madrid (Sección 10. ${ }^{\text {a) }}$ de 30 de septiembre de 2014.

${ }^{65}$ Vid. MOHÍNO MANRIQUE, Ana, en Pactos en el contrato de compraventa en interés del vendedor Dykinson 2006, pág. 349, en una interpretación analógica motivada por las raíces romanísticas del arbitraje, vemos cómo el dolo también es el límite de la exención de responsabilidades en la compraventa: «Entendemos que no es contrario a la buena fe el hecho de que el comprador hubiese válidamente aceptado un pacto por el que se eximiese al vendedor de responder en caso de evicción. Debemos tener en cuenta que la configuración de la compraventa como contrato consensual con todas sus características proviene del ius gentium, de las relaciones comerciales entre ciudadanos romanos y peregrinos, lo que permitirá configurar las obligaciones de las partes mediante convenciones accesorias. El pacto por el que se exime de responsabilidad por evicción el vendedor no afecta a tal principio, toda vez que el propio Ulpiano aclara que de existir dolo del vendedor, éste debería responder en todo caso.» 
puede liberarse a sí misma de aquellas obligaciones consustanciales al servicio que prestan a sus usuarios.

No debemos olvidar que en la elección del árbitro debe primar la confianza que en el mismo tengan las partes en lo que se refiere a su capacidad profesional, a su independencia y a su probidad, por lo que el foco debe ponerse en realizar los nombramientos correctos de los árbitros y no en tratar de prevenir las consecuencias negativas de la elección de personas inadecuadas para desarrollar la labor de árbitro.

\subsection{Responsabilidad civil}

\subsubsection{Derivada del delito}

Tanto los autores como los cómplices, cada uno dentro de su respectiva clase, serán responsables solidariamente entre sí por sus cuotas y subsidiariamente por las correspondientes a los demás responsables, con un amplio abanico en cuanto a la responsabilidad, que comprende la restitución, la reparación del daño y la indemnización de daños y perjuicios. Sin embargo, en el arbitraje administrado no tiene cabida la norma relativa a los responsables civiles, en defecto de los que lo sean criminalmente.

\subsubsection{Derivada del ordenamiento jurídico-civil}

En consonancia con su función alternativa del proceso judicial y el prestigio que debe rodear toda función de heterotutela de conflictos intersubjetivos -pese a que criminalmente razones de tipicidad impidan reputarles sujetos activos del delito de prevaricación aunque sí de cohecho-, desde una perspectiva contractualista ${ }^{66}$ de la institución derivada del antiguo contrato de «dación y recepción del arbitraje los

${ }^{66}$ Se debe subsumir el encargo arbitral en el contenido propio del contrato de mandato, pero con matizaciones determinadas por la especial naturaleza del encargo arbitral, que atribuye facultades no ya de gestión sino decisorias de una controversia que afecta a los intereses de los mandantes, y que obligan al árbitro a situarse en un plano superior que desvirtúa la mera actuación en defensa del interés del dóminus (propia del mandato) para emitir un juicio que vinculará a las partes, en posición neutral, independiente e imparcial, previa calificación de hechos, actos y conductas, con absoluta independencia de instrucciones o indicaciones del conferente del encargo. Es por ello que nosotros lo califiquemos como "contrato de mandato mixto atípico». 
árbitros responden a tenor de lo dispuesto en los artículos 1089, 1.091 y 1.101 del Código Civil; aunque en ningún caso tal responsabilidad incide en la eficacia vinculante del laudo emitido, del propio modo que las sentencias que resuelven las demandas de responsabilidad civil contra Jueces y Magistrados por negligencia o ignorancia inexcusable de los mismos en ningún caso alterarán la sentencia firme que haya recaído en el pleito o causa en que se haya ocasionado el agravio. Para que aquella responsabilidad sea exigible debe acreditarse la actuación dolosa o gravemente culposa del árbitro, el daño o perjuicio de cualquier orden padecido por los compromitentes y la relación de causalidad entre la falta y el daño ${ }^{67}$.

La Sentencia n. ${ }^{\circ}$ 429/2009 del Tribunal Supremo, Sala 1. ${ }^{\text {a }}$, de lo Civil, de 22 de Junio de 2009, ha sentado de forma definitiva las bases de lo que debe entenderse por mala fe, temeridad y dolo en materia arbitral, así como viene a delimitar de forma clara el ámbito de responsabilidad civil de los árbitros actualmente vigente, con una interpretación que afecta igualmente a la LAB y a la NLAB, fijando todos los requisitos necesarios para que efectivamente concurra una responsabilidad exigible al árbitro. En conclusión, sólo podrá apreciarse responsabilidad civil en los árbitros por los daños producidos en el

${ }^{67}$ Vid. Sentencia de Audiencia Provincial de Badajoz Sección 2. ${ }^{a}$ 11/11/1997; sentencia de Audiencia Provincial de Baleares 15/12/1995, auto Audiencia Provincial de Barcelona Sección 15 151/2010 28/09/2010; sentencia de Audiencia Provincial de Córdoba 27/04/2000; sentencia de Audiencia Provincial de Guipúzcoa 08/05/2002; sentencia de Audiencia Provincial de León Sección 3 15/11/2003; sentencia de Audiencia Provincial de Madrid Sección 10. ${ }^{a}$ 15/02/2003; sentencia de Audiencia Provincial de Madrid Sección 12 486/2014 16/10/2014; sentencia de Audiencia Provincial de Madrid Sección 13 159/2015 08/05/2015; sentencia de Audiencia Provincial de Madrid Sección 21 94/2011 15/02/2011; sentencia de Audiencia Provincial de Madrid Sección 21 409/2014 23/09/2014; sentencia de Audiencia Provincial de Madrid 24/05/1995; sentencia de Audiencia Provincial de Madrid 24/02/2001; sentencia de Audiencia Provincial de Málaga Sección 6. ${ }^{\mathrm{a}}$ 18/01/2001; sentencia de Audiencia Provincial de Salamanca 16/12/2002; sentencia de Audiencia Provincial de Vizcaya Sección 5

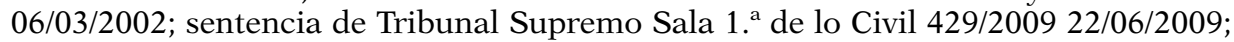
sentencia de Tribunal Supremo Sala de lo Civil 08/10/1984; sentencia de Tribunal Supremo Sala de lo Civil 29/11/1985; sentencia de Tribunal Supremo Sala de lo Civil 24/10/1986; sentencia de Tribunal Supremo Sala de lo Civil 12/06/1987; sentencia de Tribunal Supremo Sala de lo Civil 07/05/1991; sentencia de Tribunal Supremo Sala de lo Civil 22/10/1991; sentencia de Tribunal Supremo Sala de lo Civil 13/04/1992; sentencia de Tribunal Supremo Sala de lo Civil 29/03/1994; sentencia de Tribunal Supremo Sala de lo Civil 22/06/1995; sentencia de Tribunal Supremo Sala de lo Civil 25/09/1997; sentencia de Tribunal Supremo Sala de lo Civil 17/02/1998; sentencia de Tribunal Supremo Sala de lo Civil 490/1999 26/04/1999; sentencia de Audiencia Provincial de Barcelona 10/03/1992; sentencia de Audiencia Provincial de Valencia 24/03/1994; sentencia de Audiencia Provincial de Valencia 22/06/1994; sentencia de Tribunal Constitucional Sala Primera 9/2005 17/01/2005. 
ejercicio de su cometido si concurren todas las siguientes circunstancias:

La infracción cometida en el cumplimiento del encargo por los árbitros debe revestir un carácter manifiesto y, cuando menos, debe ser producto de una grave negligencia. Sólo los daños causados intencionalmente o mediando grave negligencia que comporten una infracción suficientemente caracterizada de sus deberes pueden determinar la exigencia de responsabilidad a los árbitros. Y en el arbitraje de equidad ni siquiera pueden tomarse en consideración de manera aislada la omisión de reglas o premisas de carácter formal o institucional.

Que los árbitros se hayan excedido de los límites de los inevitables márgenes de error en que se producen las actuaciones arbitrales, teniendo en cuenta el carácter necesariamente sujeto a apreciación que la aplicación del ordenamiento jurídico comporta, la aceptación de la posibilidad de error que lleva consigo el convenio arbitral si en él no se establece un sistema de revisión de la decisión arbitral y el carácter del árbitro como persona no dedicada profesionalmente al ejercicio de la potestad jurisdiccional.

De acuerdo con los principios generales en materia de responsabilidad civil, debe existir un perjuicio económico efectivo en el patrimonio o en los derechos de los interesados, producido por la actuación de los árbitros.

Debe existir un ligamen causal entre la acción u omisión de los árbitros productoras del daño o perjuicio y el resultado. Es particularmente relevante en la apreciación del nexo de causalidad la adecuación valorativa del concepto, que se logra tomando en consideración la confluencia de determinados factores, tales como la conducta de las partes o la interferencia de factores externos, que puedan enervar la posibilidad de atribuir razonablemente el daño, causado por una irregularidad en el cumplimiento de los deberes del árbitro, a la conducta del árbitro demandado en el plano de la imputación objetiva, más allá de la pura causalidad fenoménica, si dicha conducta no es suficientemente relevante.

El daño o perjuicio económico no debe poder ser reparado de otra forma, por lo que el árbitro deviene responsable en último término, es decir, la reclamación formulada en contra del árbitro no puede prosperar, por falta de requisitos, sin el agotamiento de los remedios hábiles para revisar la resolución a la que se imputa el perjuicio, bien sea la acción de aclaración y complemento, la acción de anulación prevista en la NLAB cuando sea procedente y útil o los medios de revisión que se hayan establecido válidamente en el convenio arbitral ${ }^{68}$.

${ }^{68}$ En aplicación analógica, Vid. GARCÍA GARRIDO, I Principi Generali della Tradizione Guiridica nella Unione Europea, publicado en Sciencia Giuridica interpretazione e sviluppo del diritto europeo. Jovene Editore, Roma 2011, pág. 186: «Desde el punto de vista de la técnica jurídica, la institución jurídica de la caducidad representa una concretización del principio de buena fe, y más exactamente, del principio

(C) UNED. Revista de Derecho UNED, núm. 17, 2015 
La responsabilidad que dimana del artículo 21 NLAB exige, en concordancia con lo dispuesto en el art. 217 de la L. E. C., no solo que la actuación del árbitro sea por «mala fe, temeraria o dolosa " 99 sino además que se pruebe y una cosa son los motivos de anulación que recoge el art. $41 \mathrm{NAL}$, y otra distinta, los presupuestos que el art. 21 NAL establece para la exigencia de responsabilidad. Por tanto, ni la inaplicación de la norma imperativa daría lugar por si sola a responsabilidad del árbitro de derecho; ni la responsabilidad del árbitro tiene su origen típico en la inaplicación de normas imperativas, de forma directa o de forma indirecta, a través del concepto de culpa.

jurídico que subyace al aforismo venire contra factum proprium, según el cual, en caso de actitud contradictoria del titular de un derecho, debe prohibirse al mismo el ejercicio de su derecho frente al obligado. Según el Derecho de los Estados miembros, un derecho se considerará caducado, por regla general, cuando durante determinado periodo de tiempo (componente temporal), el titular de un derecho no invoca el mismo (inacción del titular), por lo que el obligado presume, teniendo razones para ello a la luz de un análisis objetivo del comportamiento del titular del derecho (confianza legítima), que éste tampoco lo invocará en el futuro. En este caso, la vulneración del principio de buena fe radica en el retraso desleal en la invocación del derecho, por lo que el ordenamiento jurídico, habida cuenta de las circunstancias específicas del caso, considera justificada la confianza que la persona en principio obligada deposita en una situación jurídica.»

${ }^{69}$ Una vez más vemos cómo entronca directamente el arbitraje con su pasado romano, puesto que el dolo, que se configura como un elemento clave en relación con la actuación del árbitro, como nos muestra GARCÍA GARRIDO en Derecho privado romano casos acciones instituciones XX edición. Ediasa, pp. 161 y 162, contaba con una detallada regulación: «El edicto concede también una restricción total (restitutio in integrum) de los actos en que interviene intimidación. El coaccionado actúa como si el acto o negocio no hubiera tenido lugar.

"Servio definió así el dolo malo: cierta maquinación para engañar a otro, de simular una cosa y hacer otra. Labeón lo definió como: toda malicia, engaño o maquinación para valerse de la ignorancia de otro, engañarle o defraudarle». Ulpiano, $11 \mathrm{eD}$. 4. 3. 1. 2.

El derecho civil tiene en cuenta el dolo únicamente en los juicios de buena fe (bonae fidei iudicia) y cuando haya ocasionado un error grave que causa la nulidad del contrato. En la estipulación, como negocio de derecho estricto, se acostumbraba a incluir una cláusula de dolo, por la que se obligaba al deudor a prometer que no obraría con dolo. El edicto tipifica como delito «al dolo malo» y concede una acción de dolo (actio de dolo) para obtener una indemnización por el perjuicio sufrido. La fórmula se debe al jurista Aquilio Galo, que fue pretor peregrino en el año $66 \mathrm{a}$. C. La acción es infamante y se concede con carácter subsidiario, es decir, en los casos en los que no haya otra acción. Se ejercita contra el autor del dolo, dentro del año por el perjuicio sufrido, puede darse como noxal, y es intransmisible a los herederos. La acción por el enriquecimiento, que se ejercita después del año, es transmisible al heredero. El pretor concede también una exceptio doli, contra las acciones derivadas del acto viciado por dolo o por aquellas cuyo ejercicio supone un comportamiento doloso. Es probable que el pretor concediera también una rescisión total (restitutio in integrum). El delito de miedo o de coacciones psicológicas se protege mediante la actio quod metus causa.» 
No se trata de que el artículo 21 de la NLAB, suponga una derogación de la ley general en lo referente a los art. 1.101 y 1.902 del $\mathrm{CC}$, que establecen la obligación de reparar el daño causado, sino que establece un marco concreto de la responsabilidad de los árbitros que no puede ser estirado, hasta el punto de comprender también la responsabilidad por culpa, cuando se está exigiendo una estricta responsabilidad por dolo o negligencia grave, que no se puede ignorar. Estas mismas consideraciones son de aplicación con respecto a la Institución Arbitral permanente en el caso de arbitrajes administrados.

\section{OBLIGACIONES ANTERIORES A LA ACEPTACIÓN DEL ÁRBITRO QUE PUEDEN DERIVAR EN EXIGENCIAS DE RESPONSABILIDAD CIVIL}

\subsection{Examinar su capacidad para ser árbitro}

Antes de la aceptación de su nombramiento el árbitro tiene dos previas obligaciones que nacen de la NLAB: La primera es examinar si puede o no aceptar; la segunda, en su caso, la obligación de no aceptar.

El futuro árbitro vendrá obligado exclusivamente a examinar si tiene el pleno ejercicio de sus derechos civiles; si la legislación que pudiera serle de aplicación por razón de su profesión ${ }^{70}$ le prohíbe ser árbitro; y si existe un pacto en contrario de las partes para que el árbitro no sea de la nacionalidad ${ }^{71}$ del futuro árbitro. A esa lista hay que añadir, como señala mi maestro GONZÁLEZ SORIA, JULIO ${ }^{72}$, igual-

${ }^{70}$ Aunque no resulta procedente ahondar más en este punto, en nuestra opinión tal prohibición, tal y como está configurada por la Ley, únicamente podría ser aplicable en aquellos casos en que la persona física hubiera sido llamado como árbitro precisamente en razón de su profesión, que es la que justifica su elección por las partes o por el Juez. Sin embargo, puesto que lo matices resultan muy indefinidos, se habrá de cuidar al máximo cualquier posible excepción a una prohibición establecida en la legislación específica del laudante, ya que de no justificarse adecuadamente la misma claramente podría viciar el laudo de nulidad.

${ }^{71} \mathrm{Si}$ bien la NLAB no dice nada al respecto, y salvo que el acuerdo de las partes lo aclarara, entendemos que el análisis de la nacionalidad debe realizarse en el momento de la aceptación del árbitro, debiendo confrontarse la nacionalidad que en ese momento temporal concreto ostente con la prohibida o deseada por las partes.

${ }^{72}$ Cfr. GONZÁLEZ SORIA, Julio: Reflexiones básicas sobre el arbitraje. SAR. Madrid, 2015. 
mente el profundo domino del idioma del arbitraje por parte del Árbitro, que le será imprescindible para entender la documentación, para dirigir las vistas y entender a testigos, peritos y partes, así como para redactar el laudo y otros posibles documentos necesarios en el iter procesal del arbitraje.

De cara a la determinación de posibles responsabilidades civiles, nuestra opinión es que examinar erróneamente cualquier de los tres puntos anteriores habrá de ser considerado como negligencia grave o incluso dolo, si se apreciara intencionalidad dolosa, ya que pueden frustrar el arbitraje en el mismo momento en que fueren conocidos por una de las partes; o justificar la anulación del laudo si lo conocieran tras su emisión. Únicamente con relación al tercer supuesto el árbitro no incurriría en responsabilidad si las partes no hubieran incluido en el convenio arbitral la precisión de la nacionalidad y no hubieran manifestado tal circunstancia, previamente a la aceptación de su nombramiento, al árbitro.

Lógicamente, si el árbitro ocultara a las partes y, en su caso, a la institución arbitral permanente, que no cuenta con el pleno ejercicio de sus derechos civiles o que en razón de la legislación específica que le es aplicable no puede actuar como árbitro, incurriría en dolo.

De este modo, si el árbitro aceptara indebidamente el nombramiento y el procedimiento finalizara con un laudo que fuera favorable a las pretensiones de una parte, y el citado laudo fuera anulado a causa de la falta de capacidad del árbitro, existiría claramente un nexo causal entre la conducta negligente o dolosa del árbitro y el daño producido por la anulación del laudo, que es cuantificable en los costes del arbitraje que finalmente es fallido ${ }^{73}$. Por lo tanto, esa parte podría reclamar al árbitro en esos términos.

Asimismo, si el procedimiento arbitral termina antes de la emisión del laudo o del laudo que se emita -posteriormente anulado por el motivo mencionado- no se infieren derechos económicos cuantificables para la parte reclamante, la única cuantía por la que se podría reclamar al árbitro sería por los costes del procedimiento arbitral, ya que en ningún caso es admisible sostener como base de una reclamación contra un árbitro el lucro cesante de una supuesta resolución

${ }^{73}$ En ningún caso entendemos que puedan ser reclamados los costes del siguiente procedimiento arbitral o judicial que la parte reclamante hubiera iniciado para defender sus intereses, inicialmente sometidos a arbitraje, porque para ello en cualquier caso siempre deberá soportar los costes de 1 procedimiento. 
favorable a sus intereses si hubiera sido otro el árbitro, máxime cuando tras la anulación le quedan expeditas la vía arbitral y la estática, según lo que disponga el convenio arbitral aplicable.

\subsection{Examinar su competencia y predisposición para ser árbitro}

De cara a la determinación de posibles responsabilidades civiles, nuestra opinión es que en este caso no se pueden derivar consecuencias directas relativas a la responsabilidad del árbitro, dado el carácter subjetivo y variable de las valoraciones que debe hacer el futuro árbitro, sino que se habría de esperar a ver si una incorrecta evaluación de su competencia profesional y/o de su disponibilidad de tiempo afectan al desarrollo del procedimiento, pudiendo llegar a constituir una negligencia grave.

Lógicamente, si el árbitro aceptara un arbitraje de derecho con un complicado contenido jurídico que versara sobre una materia en la que no contara con experiencia alguna, y este desconocimiento afectara el curso del procedimiento, llegando a producirse un laudo contrario al orden público que fuera posteriormente anulado, la imprudencia del árbitro sería tal que habría de ser calificada como de negligencia grave.

Y si aceptara un arbitraje, aún a sabiendas de que en ese momento sus circunstancias personales le iban a impedir dedicar el tiempo suficiente para mantener el impulso procesal del procedimiento y para profundizar en el conocimiento de la litis, y finalmente dictara un laudo extemporáneo, que fuera posteriormente anulado, al haber fijado las partes convencionalmente un plazo preclusivo, su imprudencia habría de ser calificada de negligencia grave.

De este modo, si el árbitro acepta indebidamente el nombramiento y el procedimiento finaliza con un laudo que es favorable a las pretensiones de una parte, y el citado laudo es anulado por contrario al orden público o por extemporáneo, existiría claramente un nexo causal entre la conducta negligente o dolosa del árbitro y el daño producido por la anulación del laudo, que es cuantificable en los costes del arbitraje que finalmente es fallido. Por lo tanto, esa parte podrá reclamar al árbitro en esos términos.

Asimismo, si el procedimiento arbitral terminara antes de la emisión del laudo o del laudo que se emitiera -posteriormente anulado 
por uno de los dos motivos mencionados- no se infieren derechos económicos cuantificables para la parte reclamante, la única cuantía por la que se podría reclamar al árbitro sería por los costes del procedimiento arbitral.

\subsection{Contar con un seguro de Responsabilidad Civil}

Dentro de la revisión de la competencia del árbitro antes de su aceptación, tiene la obligación, a tenor de la NLAB, de comprobar que tenga un seguro de responsabilidad civil o garantía equivalente en vigor y si no, rehusar el nombramiento. Desgraciadamente el Legislador aún no ha llevado a cabo el desarrollo reglamentario de este artículo, por lo que de facto todos los árbitros están incumpliendo en la actualidad una norma imperativa que, por aplicación analógica con las profesiones colegiadas, les cerraría la posibilidad de actuar como árbitros. Sin embargo, como el incumplimiento es imputable a la Administración, por su prolongada demora en el preceptivo desarrollo reglamentario, no tiene efectos prácticos y no se pueden exigir responsabilidad al árbitro por aceptar el nombramiento sin tener un seguro o garantía equivalente.

\subsection{Examinar posibles conflictos de intereses}

El deber de revelación por parte de los árbitros se articula como el principal instrumento legislativo de prevención de conflictos de intereses en el seno de un arbitraje, habida cuenta de la práctica imposibilidad para una parte de conocer todas las posibles relaciones que puedan existir entre su contraparte y un árbitro; y como medio para resolver los supuestos dudosos -en aquellos en que el conflicto es evidente el árbitro debería directamente abstenerse de participar en el procedimiento-, pues al tener conocimiento de las circunstancias son las partes quienes decidirán si lo consideran o no un obstáculo suficiente para la participación del árbitro en el procedimiento ${ }^{74}$.

En una situación en la que la apreciación de si se producen o no dudas justificadas sobre la independencia e imparcialidad del árbitro

${ }^{74}$ Vid. Sentencia n. ${ }^{\circ}$ 221/2008, de 5 de mayo, de la Audiencia Provincial de Madrid; Sentencia n. ${ }^{\circ}$ 44/2015 del Tribunal Superior de Justicia de la Comunidad de Madrid, Sala de lo Civil y lo Penal, de 26 de mayo de 2015; y Sentencia n. ${ }^{\circ}$ 25/2014 del Tribunal Superior de Justicia de Aragón, Sala de lo Civil y lo Penal, de 25 de Junio de 2014. 
depende no solo del juicio de este, sino también de la consideración subjetiva de las partes, la mejor alternativa es revelar todo lo que directamente crea que debe revelar y además lo que dude si debe revelar, teniendo siempre presente que el hecho de que un árbitro revele determinadas circunstancias no puede entenderse como la admisión de la existencia de un conflicto de intereses, si no justo lo contrario.

En el año 2004 se promulgaron las Directrices de la IBA sobre Conflictos de Intereses en Arbitraje Internacional, con el fin de fijar las pautas de determinación de la existencia de conflictos de interés. Su aceptación en el ámbito internacional se encuentra fuera de toda duda pero su aplicación plantea aún algunos interrogantes, pues por un lado resulta cuestionable la existencia de una lista de supuestos no renunciables ya que, en virtud del principio de la autonomía de la voluntad, si las partes, conociendo la existencia de las situaciones incluidas en la lista, deciden igualmente designar a una persona determinada como árbitro, limitar sus elecciones y su consentimiento debidamente informado no parece justificado; y, por otro lado, como ya antes fue apuntado, debe evitarse el riesgo de aplicar sin más las distintas listas, sin analizar las circunstancias específicas de cada caso, fundamentalmente si se decide no revelar situaciones contenidas en la categoría verde que respecto a un supuesto concreto sí podrían generar dudas justificadas sobre la imparcialidad o independencia de uno de los árbitros.

La primera consecuencia que, sobre el procedimiento arbitral, tiene la no revelación de situaciones potencialmente conflictivas se plantea en relación con la recusación del árbitro en el momento en que dichas situaciones se descubren. Así, en cuanto se plantea la recusación, el procedimiento se paraliza con el fin de resolver aquella. Si además está ya avanzado el procedimiento arbitral, la recusación puede conducir a un considerable desajuste que podría haberse evitado con la oportuna revelación. Además, la falta de revelación puede llegar a cualificar la causa de recusación al potenciar las dudas que puedan surgir en relación con la misma. En términos de responsabilidad del árbitro, esta será exigible en supuestos de mala fe, temeridad o dolo ${ }^{75}$.

La otra vertiente del incumplimiento del deber de revelación, en relación con sus efectos sobre el procedimiento arbitral, es la cuestión de si el mero incumplimiento del deber de revelación es suficiente para obtener la anulación del laudo. Nuestra opinión es que puesto que es un deber instrumental, dirigido a que las partes tengan un conocimiento suficiente de las circunstancias que puedan dar lugar a dudas fundadas sobre la imparcialidad e independencia de los árbi-

${ }^{75}$ Art. 21.1 NLAB. 
tros, sólo en supuestos en los que las circunstancias no reveladas generen tales dudas es cuando puede cuestionarse la validez del arbitraje. Porque no hay que olvidar que no se trata de determinar si, efectivamente, el árbitro no es imparcial o independiente, si no de analizar hasta qué punto sus relaciones con las partes o sus defensores permiten sembrar en la otra parte la fundada duda sobre tales atributos, es decir, que se valora esa apariencia previa de imparcialidad e independencia, que cuando no se produce es insalvable por medio de una conducta imparcial e independiente del árbitro en el arbitraje.

Cabe además señalar que el árbitro, al revelar la existencia de situaciones potencialmente conflictivas, está salvaguardando no solo el procedimiento, sino también su propio nombramiento dado que, una vez puestas aquellas en conocimiento de las partes, si estas no formulan la recusación en el plazo que corresponda ${ }^{76}$, se entiende que han renunciado tácitamente a las facultades de impugnación que les otorga la NLAB, salvando en consecuencia el posible conflicto de interés, conforme al artículo 6 NLAB, ya que al no plantear la recusación esa parte tiene vetado después impugnar el laudo arguyendo este motivo.

Debemos entender como negligencia grave no revelar una circunstancia que objetivamente puede proyectar sombras de duda sobre la independencia e imparcialidad del árbitro, por creer éste que ello no era necesario o preceptivo. Y como dolo, la ocultación de la citada circunstancia, al pensar que de revelarla sobrevendría su recusación. En este segundo caso, habría incumplido igualmente la obligación de rehusar al nombramiento, que como hemos visto puede generar responsabilidades. Sin embargo, no tiene sentido acumularlas, porque son las dos caras de una misma moneda. La importancia de que nos encontremos con dolo o negligencia grave en la actuación del árbitro se verá en la cuantificación que el Juez de Primera Instancia que resuelva la reclamación contra el árbitro haga de la indemnización, pues podrá decidir atemperar la misma cuando concurra negligencia grave.

De este modo, si el árbitro incumple el deber de revelación y el procedimiento finaliza con un laudo que es favorable a las pretensiones de una parte, y el citado laudo es anulado a causa de la falta de independencia aparente del árbitro, existe claramente un nexo causal entre la conducta negligente o dolosa del árbitro y el daño producido por la anulación del laudo, que es cuantificable en los costes del arbi-

\footnotetext{
${ }^{76}$ Quince días salvo que las partes hayan acordado otra cosa, ex art. 18.2 NLAB.
} 
traje que finalmente es fallido. Por lo tanto, esa parte podrá reclamar al árbitro en esos términos ${ }^{77}$.

Asimismo, si el procedimiento arbitral termina antes de la emisión del laudo o del laudo que se emita -posteriormente anulado por el motivo mencionado- no se infieren derechos económicos cuantificables para la parte reclamante, la única cuantía por la que podría reclamar al árbitro sería por los costes del procedimiento arbitral, ya que en ningún caso es admisible sostener como base de una reclamación contra un árbitro el lucro cesante de una supuesta resolución favorable a sus intereses si hubiera sido otro el árbitro, máxime cuando tras la anulación le quedan expeditas la vía arbitral o la estática.

\subsection{Examinar la viabilidad del arbitraje a tenor del convenio arbitral}

\subsubsection{Posible desistimiento del convenio arbitral}

La exclusión de la jurisdicción debe realizarse a través de la declinatoria, lo que impide al Juez que conozca de la misma entrar en el fondo del asunto $^{78}$. De este modo:

A) Si el demandado decide invocar el convenio arbitral, debe hacerlo al principio del proceso, en el momento en que comparezca o inmediatamente después de comparecido, puesto que si el demandado conserva el derecho a renunciar expresa o tácitamente al arbitraje contestando a la demanda, debe exigírsele que lo haga a limine, pues en caso contrario la actividad procesal realizada devendría inútil e ineficaz.

${ }^{77}$ La otra parte, que es con la que el árbitro se supone tiene relación, al no haber manifestado durante el arbitraje su preocupación ante esa situación ni haber instado la anulación del laudo, ha incumplido lo previsto en el artículo 6 NLS y decaído en sus derechos de reclamación al árbitro por ese motivo.

${ }^{78}$ Vid. Sentencia de Tribunal Superior de Justicia Castilla La Mancha Sala de lo Civil y Penal 4/2013 de 10/10/2013; Sentencia de Tribunal Supremo Sala de lo Civil 355/1998 de 18/04/1998; Sentencia de Tribunal Supremo Sala de lo Civil 966/1998 de 27/10/1998; Sentencia de Tribunal Supremo Sala de lo Civil 490/1999 de 01/06/1999; Sentencia de Tribunal Supremo Sala de lo Civil 1042/1999 de 11/12/1999; Sentencia de Tribunal Supremo Sala de lo Civil 724/2001 de 13/07/2001; Sentencia de Tribunal Supremo Sala de lo Civil 245/2002 de 18/03/2002 ; Sentencia de Tribunal Supremo Sala de lo Civil 64/2003 de 06/02/2003 ; Sentencia de Tribunal Supremo Sala de lo Civil 688/2003 de 03/07/2003; Sentencia de Tribunal Supremo Sala de lo Civil 771/2003 de 26/07/2003; Sentencia de Tribunal Supremo Sala de lo Civil, Sección Única 1000/2003 de 30/10/2003. 
B) Invocado el convenio arbitral, la cuestión debe ser resuelta con carácter previo, pues la eficacia del convenio arbitral no sólo excluye la decisión de la controversia por los Tribunales ordinarios, sino que también excluye la actividad procesal misma. Si una de las metas del arbitraje es obtener una decisión rápida y menos costosa, parece evidente que es preciso evitar la propia actividad procesal, aunque ésta termine con una sentencia absolutoria de la instancia.

C) La única finalidad de la declinatoria es obtener el sobreseimiento del proceso en el que se interpone y quedarse ahí (65.2 LEC). El efecto negativo o excluyente del convenio arbitral sólo asegura que será sobreseído el proceso jurisdiccional iniciado sobre materia sometida a arbitraje, pero no permite -en ese momento- «obligar» al actor a acudir al arbitraje pactado. Incluso obtenido el sobreseimiento del proceso, nada obliga al demandado a acudir al arbitraje. Hacerlo o no queda a su albedrío y, si decide obligar al actor acudir al arbitraje (arts. 38 y ss. NLAB) lo hace en completa desconexión del proceso inicialmente incoado.

Así pues, si una de las partes ha iniciado un proceso jurisdiccional y la otra parte no se ha limitado a interponer en plazo y forma la correspondiente declinatoria de sumisión a arbitraje sino que ha realizado cualquier otra actuación procesal, el árbitro debe considerar extinguida la voluntad de las partes de someter la decisión de su litis al árbitro, por lo que debe cesar en el procedimiento arbitral. Hacer lo contrario, es decir, continuar con el arbitraje a petición de la parte que no ha interpuesto la declinatoria, existiendo un procedimiento judicial en el que ambas partes estén personadas, podría ser calificado de negligencia grave o incluso de dolo, ya que conducirá indefectiblemente a un laudo viciado, incurso en una de las causas tasadas de anulación, como es la nulidad del convenio arbitral.

En el caso de que la parte demandada haya iniciado un procedimiento judicial y la parte demandante haya presentado la declinatoria de sumisión a arbitraje, el árbitro puede plantearse los siguientes escenarios:

Declarar la validez del convenio arbitral y, por ende, de su competencia, y continuar el procedimiento hasta la emisión del laudo, con independencia del fin que tenga la declinatoria.

Suspender, con el acuerdo de las partes, el procedimiento arbitral, hasta que se resuelva la declinatoria, continuando el procedimiento en el caso de que sea admitida. 
Continuar con el procedimiento arbitral, al haber admitido su competencia, y si antes de la emisión del laudo recae la decisión sobre la declinatoria rechazando la misma, estudiar la fundamentación de la misma y volver a revisar su propia competencia.

En ninguno de los tres escenarios anteriores parece fácil encontrar un supuesto en los que se pueda apreciar dolo o grave negligencia en la actuación del árbitro, salvo el caso en el que el convenio arbitral fuera manifiestamente nulo y se pudiera apreciar de forma incontrovertida tal nulidad, y el árbitro hubiera decidido ignorarlo, declarando su competencia para continuar con el procedimiento arbitral y ello condujera posteriormente a la anulación del laudo, produciéndose daños para las partes que hubieran podido evitarse con la conducta especialmente diligente que se le exige al árbitro. Sin embargo, es importante enfatizar que el hecho de que en la acción de impugnación el Tribunal Superior de Justicia competente estime la anulación por invalidez del convenio arbitral no presupone per se la responsabilidad del árbitro, ya que se trata de una materia de contenido jurídico, susceptible de controversia en muchos casos. Ni siquiera se derivarían esos efectos de responsabilidad directa si antes de laudar se desestimara la declinatoria, puesto que no olvidemos que ese Auto es susceptible de reposición y después de Alzada, lo que demoraría previsiblemente el proceso más allá del ámbito previsto para laudar, cabiendo la posibilidad de que la Audiencia Provincial modifica la decisión desestimatoria del juez a quo.

\subsubsection{Caducidad del convenio arbitral}

El árbitro es libre de decidir si trata la caducidad del convenio como una cuestión previa o por el contrario resuelve la misma, tras finalizar el procedimiento arbitral, en el laudo, si bien se le exige buena fe y la mejor de las diligencias para optar por la alternativa que prima facie resulte menos gravosa para las partes litigantes, en el bien entendido de que en este caso lo que el árbitro asume es un mero compromiso de buena voluntad y de razonabilidad en su decisión procedimental, pero en ningún caso una obligación de acertar con la alternativa que finalmente hubiera podido revelarse como la preferible para los intereses de las partes y del propio arbitraje $\mathrm{e}^{79}$.

Desde la óptica de la responsabilidad de los árbitros, nuestra sugerencia sería resolver siempre las excepciones con carácter previo en aquellos casos en los que prima facie el árbitro aprecie un fumus boni

${ }^{79}$ Vid. Sentencia de Tribunal Supremo de 16 de junio de 1947. 
iuris en la excepción solicitada que pudiere hacer que llegara a ser aceptada, en lugar de esperar a recogerlas en el laudo, porque de apreciarse alguna de las excepciones que supusieran las frustración del arbitraje, resultaría más gravoso por las partes, tanto en tiempo como en costes, que hubiera continuado el procedimiento arbitral y se hubiera emitido el laudo, habiendo pasado por la fase de pruebas y de conclusiones. No obstante, no hacerlo así en ningún caso puede suponerle una responsabilidad al árbitro en el caso de que finalmente aceptara la excepción en su laudo, puesto que la NLAB le autoriza a hacerlo.

Por el contrario, cuando prima facie las excepciones se antojan improcedentes, resulta más adecuado que el árbitro espere a resolverlas en el laudo final, como parte del mismo, ya que de esa manera se asegura el árbitro una mayor coordinación y consistencia interna del laudo, con sus argumentaciones alimentando de forma fluida y cohesionada todas las decisiones vertidas en el mismo.

\subsubsection{Nulidad del convenio arbitral}

Los requisitos del objeto y causa del convenio arbitral coinciden en su por qué jurídico, siendo precisa, bajo pena de nulidad, su existencia, su licitud y su determinación ${ }^{80}$. En relación con el objeto del

${ }^{80}$ Vid. Sentencia del Tribunal Constitucional, Pleno, 174/1995 de 23/11/1995; Sentencia del Tribunal Constitucional, Sala Primera, 75/1996 de 30/04/1996; Sentencia del Tribunal Supremo, Sala de lo Civil, de 08/07/1930; Sentencia del Tribunal Supremo, Sala de lo Civil, de 14/03/1974; sentencia de Audiencia Provincial, Granada Sección 4 10/2015 de 16/01/2015; sentencia de Tribunal Superior de Justicia, Comunidad de Madrid Sala de lo Civil y Penal 56/2015 de 13/07/2015; sentencia de Tribunal Supremo, Sala de lo Civil de 26/02/1946; sentencia de Tribunal Supremo, Sala de lo Civil de 25/04/1975; sentencia de Tribunal Supremo, Sala de lo Civil de 09/04/1941; sentencia de Tribunal Supremo, Sala de lo Civil de 29/04/1952; sentencia de Tribunal Supremo, Sala de lo Civil de 04/06/1965; sentencia de Tribunal Supremo, Sala de lo Civil de 06/06/1933; sentencia de Tribunal Supremo, Sala de lo Civil de 06/12/1941; sentencia de Tribunal Supremo, Sala de lo Civil de 07/07/1953; sentencia de Tribunal Supremo, Sala de lo Civil de 21/01/1961; sentencia de Tribunal Supremo, Sala de lo Civil de 04/06/1980; sentencia de Tribunal Supremo, Sala de lo Civil de 16/03/1987; sentencia de Tribunal Supremo, Sala de lo Civil de 11/12/1987; sentencia de Tribunal Supremo, Sala de lo Civil de 17/03/1988; sentencia de Tribunal Supremo, Sala d e lo Civil de 09/11/1953; sentencia de Tribunal Supremo, Sala de lo Civil de 07/10/1931; sentencia de Tribunal Supremo, Sala de lo Civil de 10/05/1941; sentencia de Tribunal Supremo, Sala de lo Civil de 02/01/1964; sentencia de Tribunal Supremo, Sala de lo Civil de 20/03/1990; sentencia de Tribunal Supremo, Sala de lo Civil de 31/03/1981; sentencia de Tribunal Supremo, Sala de lo Civil de 03/05/1961; sentencia de Tribunal Supremo, Sala de lo Civil de 18/06/1966; sentencia de Tribunal Supremo, Sala de lo Civil de 07/07/1969; sentencia de Tribunal Supremo, Sala de lo Civil de 21/02/1970; sentencia de Tribunal Supremo, Sala de lo Civil de 14/07/1989; sentencia de Tribunal Superior 
convenio, son tres los aspectos esenciales que conviene tener en cuenta para determinar la posible inexistencia del objeto: En primer término, es presupuesto del arbitraje la existencia de un negocio principal, que puede ser o no un contrato; en segundo, ha de determinarse cuál es la relación jurídica singular de dicho negocio sobre la que ha de recaer el arbitraje; y, finalmente, cuáles son los puntos concretos que configuran la controversia sometida a los árbitros.

Las cuestiones litigiosas deben surgir de relaciones jurídicas determinadas, sean o no contractuales, por lo que la existencia de un negocio principal sobre el que se funda la res litigiosa es un prius lógico y si falta, el convenio no sólo es nulo, sino inexistente.

Se debe determinar en el convenio la relación jurídica singular a la que ha de referirse el arbitraje o, en su defecto, indicarse la relación jurídica de donde pueda surgir, so pena de nulidad.

El objeto y la causa del convenio es la controversia, es decir, aquellas cuestiones litigiosas, presentes o futuras, entre partes, que ha de

de Justicia, Comunidad Valenciana Sala de lo Civil y Penal 14/2012 de 26/04/2012; sentencia de Tribunal Supremo, Sala de lo Civil de 07/07/1924; sentencia de Tribunal Supremo, Sala de lo Civil de 27/01/1953; sentencia de Tribunal Supremo, Sala de lo Civil de 17/06/1944; sentencia de Tribunal Supremo, Sala de lo Civil de 14/10/1947; sentencia de Tribunal Supremo, Sala de lo Civil de 28/02/1962; sentencia de Tribunal Supremo, Sala de lo Civil de 04/05/1962; sentencia de Tribunal Supremo, Sala de lo Civil de 22/01/1972; sentencia de Tribunal Supremo, Sala de lo Civil de 20/11/1989; sentencia de Tribunal Supremo, Sala de lo Civil de 13/10/1986; sentencia de Tribunal Supremo, Sala de lo Civil de 28/10/1933; sentencia de Tribunal Supremo, Sala de lo Civil de 02/10/1946; sentencia de Audiencia Provincial, Asturias Sección 1. ${ }^{a}$ 25/2004 de 20/01/2004; sentencia de Audiencia Provincial, Málaga de 12/02/2001 ; sentencia de Audiencia Provincial , Sevilla de 15/03/2001 ; sentencia de Audiencia Provincial, Valencia de 19/04/2000; Resolución de Dirección General Registros y Notariado, de 19/02/1998; Resolución de Dirección General Registros y Notariado, de 18/04/1998; Resolución de Dirección General Registros y Notariado, de 01/10/2001; sentencia de Tribunal Supremo, Sala de lo Civil de 16/11/1933; sentencia de Tribunal Supremo, Sala de lo Civil de 15/10/1956; sentencia de Tribunal Supremo, Sala de lo Civil de 06/03/1987; sentencia de Tribunal Supremo, Sala de lo Civil 1139/2001 de 30/11/2 001; sentencia de Tribunal Supremo, Sala de lo Civil de 21/01/1975; sentencia de Audiencia Provincial, Barcelona Sección 14. a de 03/10/2003; Auto de Audiencia Provincial, Barcelona Sección 14. ${ }^{a}$ 846/2003 de 17/10/2003; sentencia de Tribunal Superior de Justicia, Comunidad de Madrid Sala de lo Civil y Penal 32/2014 de 02/06/2014; sentencia de Tribunal Superior de Justicia, Comunidad de Madrid Sala de lo Civil y Penal 31/2015 de 14/04/2015; sentencia de Tribunal Supremo, Sala de lo Civil, Sección Única 433/2003 de 09/05/2003; Auto de Tribunal Supremo, Sala de lo Civil de 26/05/1998; Auto de Tribunal Supremo, Sala de lo Civil de 14/07/1998; Auto de Tribunal Supremo, Sala de lo Civil de 29/09/1998; Auto de Tribunal Supremo, Sala de lo Civil de 18/04/2000; sentencia de Tribunal Supremo, Sala de lo Civil 245/2002 de 18/03/2001; sentencia de Tribunal Supremo, Sala de lo Civil 790/2001 de 23/07/2001; Auto de Tribunal Supremo, Sala de lo Civil de 14/10/2003; sentencia de Tribunal Supremo, Sala de lo Civil, Sección Única 688/2003 de 07/03/2003. 
tratarse de una res dubia y que puede ser un conflicto intersubjetivo, una controversia de alcance verdaderamente objetivo o incluso un conflicto de actividades. Es posible formalizar el convenio arbitral sobre la base de controversias potenciales, y en el caso de que las partes no concreten las citadas controversias antes del inicio del arbitraje, será responsabilidad de los árbitros hacerlo ${ }^{81}$. Lógicamente, la controversia no debe haber quedado extinguida mediante sentencia judicial, arbitraje, transacción u otro acto jurídico.

La exigencia objetiva de licitud se concreta, en el caso del convenio arbitral, en lo que se ha dado en llamar arbitrabilidad de la controversia o idoneidad de la misma para ser objeto de un acuerdo de arbitraje, lo que significa que sólo son susceptibles de arbitraje las controversias sobre materias de libre disposición conforme a Derecho. Este defecto es de tal naturaleza que, incluso si el laudo no fuera impugnado, no producirá efectos por tratarse de un vicio insubsanable y además, en nuestra opinión, el laudo podría ser declarado nulo ${ }^{82}$ de oficio, si, habiendo sido impugnado por las partes, no hubieran invocado este motivo de nulidad.

En conclusión, el laudo será nulo si los árbitros deciden puntos no sometibles a arbitraje. La razón de ser de este motivo es que los árbitros no pueden hacer lo que a las partes les está vedado y, consecuentemente, aquellos derechos que son irrenunciables y aquellas cuestiones que provocarían el ejercicio de una acción constitutiva necesaria deberán ser hechos valer en el proceso judicial correspondiente. No existe una relación cerrada de materias indisponibles, con excepción de menciones especificas a los ámbitos laborales, consumerista y de telecomunicaciones, así como de la asunción de que no podrán ser arbitrables cuestiones sobre las que ha recaído resolución judicial firme y definitiva; materias inseparablemente unidas a otras sobre las que las partes no tengan poder de disposición y cuestiones en que, con arreglo a las Leyes, deba intervenir el Ministerio Fiscal en representación y defensa de quienes, por carecer de capacidad de obrar o de representación legal, no pueden actuar por sí mismos.

${ }^{81}$ En esos casos el laudo no podría impugnarse por el motivo de la nulidad del convenio, sino por el motivo de incongruencia si los árbitros se hubieran excedido en la delimitación de la controversia.

${ }^{82}$ Será nulidad parcial, si se trata de puntos que tengan sustantividad propia y que no aparezcan unidos indisolublemente a otros. 
En principio el convenio arbitral deberá constar por escrito, en un documento $^{83}$ firmado por las partes o en un intercambio de cartas, telegramas, télex, fax u otros medios de telecomunicación que dejen constancia del acuerdo. Sin embargo, la forma del convenio arbitral es muy flexible ${ }^{84}$, pudiendo aparecer como un acuerdo independiente del contrato, surgido, incluso, de correspondencia intercambiada entre las partes o hasta por la ausencia de negación de una de ellas cuando se alega su existencia por la contraria en un procedimiento judicial. Incluso, ante la ausencia de un acuerdo arbitral firmado por las partes, se habrá de atender no sólo a criterios integradores de índole sistemática, acudiendo incluso a otras normas convencionales cuando fuesen aplicables, sino especialmente a criterios de tipo finalista, considerando que el objeto de la norma es verificar la existencia de la voluntad común de las partes dirigida a incluir en el contenido de sus relaciones negociales un convenio arbitral o, en general, encaminada a someter a arbitraje los litigios que se susciten con motivo de la ejecución de un determinado negocio jurídico entre ellos; voluntad común que ha de resultar del conjunto de las comunicaciones mantenidas y de las actuaciones llevadas a cabo por una y otra parte de la relación negocial, pero siempre con la obligada precisión de que, sin embargo, no cabe atribuir a estos fines eficacia al silencio o inactividad de aquélla a la que se le hubiera dirigido una oferta que, directa o indirectamente, contenga un convenio arbitral.

En cuanto a la redacción del convenio arbitral, basta que su sentido resulte claramente expresado, por haberse convenido y aceptado, reflejando consentimientos bilaterales concurrentes para estimar suficiente y vinculante el contenido de la cláusula, ya que no debe confundirse la forma del negocio jurídico con las superadas fórmulas sacramentales.

En conclusión, el convenio arbitral, como todo contrato, debe cumplir los requisitos generales previstos en el C. C. y los específicos de la NLAB, y si no se cumpliera alguno de estos requisitos en rela-

${ }^{83}$ Puede ser parte de un contrato de adhesión siempre que no vaya en contra de normas específicas que lo prohíben, como es el caso de que una de las partes sea un consumidor, pues en esa caso sólo es posible el arbitraje de consumo.

${ }^{84}$ Como nos recuerda GARCÍA GARRIDO, esta tradición antiformalista se remonta hasta el Ordenamiento de Alcalá. Vid. Las influencias Romana e hispana en la historia del contrato publicado en homenaje a José Antonio Escudero. Madrid 2012: «El Ordenamiento de Alcalá, que se incluye con alguna variante en la Nueva y en la Novísima Recopilación, al consagrar la libertad de formas y aceptar la doctrina sobre la causa, termina con todas las interminables polémicas de glosadores y canonistas sobre pactos nudos o vestidos, contratos innominados o nominados, estipulaciones con o sin causa, entre presente y ausentes. Sin embargo, estos conceptos tienen todavía huellas en los autores del siglo XVIII». 
ción con las partes, con el objeto, con la forma o con el tiempo, pudiere el laudo anularse en impugnación ${ }^{85}$. De este modo, la responsabilidad del árbitro pudiera llegar a exigirse en los siguientes escenarios:

A) El árbitro no aprecia vicio en las voluntades en el nacimiento jurídico del convenio arbitral, a pesar de que la parte que dice haberlo sufrido se lo ponga de manifiesto y continua el procedimiento, emitiendo su fallo, que posteriormente es anulado precisamente por nulidad del convenio arbitral, por no existir una voluntad concorde de las partes de sustraerse del juez predeterminado.

B) El árbitro aprecia, de oficio o porque se lo someta una de las partes, vicio en las voluntades en el nacimiento jurídico del convenio arbitral, y da por finalizado el procedimiento arbitral, dejando a las partes expedita la vía judicial.

C) El árbitro no aprecia la falta total o absoluta del negocio principal sobre el que se funda la res litis, a pesar de que una parte se lo ponga de manifiesto y continua el procedimiento, emitiendo su fallo, que posteriormente es anulado precisamente por nulidad del convenio arbitral, por no existir el citado negocio principal

D) El árbitro aprecia, de oficio o porque se lo someta una de las partes, la falta total o absoluta del negocio principal sobre el que se funda la res litis, y da por finalizado el procedimiento arbitral, dejando a las partes expedita la vía judicial.

E) El árbitro no aprecia la falta de la relación jurídica singular a la que ha de referirse el arbitraje, a pesar de que una parte se lo ponga de manifiesto y continua el procedimiento, emitiendo su fallo, que posteriormente es anulado precisamente por nulidad del convenio arbitral, por no existir la citada relación jurídica singular.

F) El árbitro aprecia, de oficio o porque se lo someta una de las partes, la falta de la relación jurídica singular a la que ha de referirse el arbitraje, y da por finalizado el procedimiento arbitral, dejando a las partes expedita la vía judicial.

${ }^{85}$ Señala MOHINO MANRIQUE, Ana, Vid. A propósito de D.19.2.20.2 en relación con D.19.2.22.pr. Universidad Nacional Educación a Distancia, UNED: «El simple consentimiento de los contratantes, exento de toda forma, permitió, enmarcado en el principio de la buena fe obtener finalidades muy diversas según las necesidades del tráfico jurídico.» Sin embargo, el Legislado de la NLAB no ha querido llegar tan lejos. 
G)El árbitro no aprecia no aprecia inexistencia de la controversia, a pesar de que una parte se lo ponga de manifiesto y continua el procedimiento, emitiendo su fallo, que posteriormente es anulado precisamente por nulidad del convenio arbitral, por inexistencia de la controversia.

H)El árbitro aprecia, de oficio o porque se lo someta una de las partes, inexistencia de la controversia, y da por finalizado el procedimiento arbitral, dejando a las partes expedita la vía judicial.

I) El árbitro procede a determinar una controversia que las partes no habían concretado y una de ellas manifiesta que se ha extralimitado en esa determinación y el árbitro no redefine la controversia, y posteriormente el laudo es anulado por incongruente.

J) El árbitro no aprecia que el convenio arbitral versa sobre materia indisponible, a pesar de que una parte se lo ponga de manifiesto y continua el procedimiento, emitiendo su fallo, que posteriormente es anulado precisamente por nulidad del convenio arbitral, por conocer de materia indisponible.

K)El árbitro aprecia, de oficio o porque se lo someta una de las partes, la indisponibilidad de la materia sobre la que versa el convenio arbitral, y da por finalizado el procedimiento arbitral, dejando a las partes expedita la vía judicial.

Como ya hemos comentado anteriormente, para determinar la posible responsabilidad de árbitro a tenor de la precitada relación de hechos factuales, se debe evaluar la intencionalidad; el daño cierto y cuantificable producido; y el nexo causal entre el hecho factual y el daño.

Comenzando con la intencionalidad, en nuestra opinión en todos los casos tendría cabida el dolo, si el árbitro es movido en sus decisiones por la voluntad de causar perjuicio a una de las partes. En cuanto a la negligencia grave, tendría mejor cabida en las letras j) y k), puesto que con contadas excepciones, no resulta un ejercicio jurídico excesivamente complejo determinar qué materia es arbitrable y cual no, por lo que cometer un error en ese ámbito podría llegar a demostrar una negligencia grave ${ }^{86}$. Lógicamente, cuando más compleja sea la relación jurídica a interpretar por el árbitro, más margen para el

\footnotetext{
${ }^{86}$ Un buen ejemplo sería un convenio arbitral incluido en un contrato de adhesión suscrito entre una empresa y un consumidor. El árbitro que no considerara nulo ese convenio incurriría en negligencia grave por no demostrar la especial diligencia que se le exige en su actuación como árbitro.
} 
error tendrá, moviéndose entonces en el terreno de la culpa, que recordemos no es suficiente para instar una reclamación por responsabilidad contra el árbitro.

En cuanto al daño producido, podemos agrupar por un lado las letras a), c), e), g), j), en las que se produce la misma circunstancia, es decir, un procedimiento arbitral que llega hasta el final y el laudo que se emite en anulado por el motivo desestimado en su momento por el árbitro; por otro, las letras b), d), f), h) y k), que se caracterizan porque el árbitro haya decidió estimar la nulidad del convenio y poner fin a la vía arbitral; y finalmente la i), que no se corresponde con la nulidad del convenio sino con la incongruencia del laudo con la controversia.

Sin embargo, a efectos de determinar el daño, todas ellas se tratarían de la misma forma, puesto que el mismo debiera centrarse en los costes del arbitraje que hubiera soportado la parte reclamante., que serán mayores en el primer grupo de hechos factuales por haberse completado el arbitraje. Como hemos señalado con anterioridad, en ningún caso se puede considerar como un daño infligido a una parte verse privada de la jurisdicción arbitral y tener que recurrir a la jurisdicción estática para resolver la litis, porque es impropio presuponer que se obtendrá una mejor decisión en uno u otro ámbito. En el caso de la incongruencia, la determinación del daño es aun más compleja, puesto que normalmente se producirá una anulación parcial del laudo. Lógicamente, el grado de intencionalidad debería atemperar la cuantificación del daño.

En cuanto al nexo causal entre la conducta del árbitro y el daño causado en evidente y directo, ya que en el primer grupo de opciones, es su conducta la que justifica la anulación del laudo y, por ende el fracaso, del esfuerzo arbitral; y en el segundo es el propio árbitro quien decide cesar y terminar el arbitraje sin la conclusión que le da sentido, el laudo.

Es importante volver a insistir en que la parte que no hubiera puesto de manifiesto durante el procedimiento una posible causa de anulación, no podría instarla en la acción de impugnación y, por ende no podrían reclamar responsabilidades al árbitro por ella. De este modo, en ningún caso prosperaría que la parte que no cuestionó la validez del convenio arbitral, una vez anulado el laudo, en que se le asignaban determinados derechos económicos, reclamara al árbitro una indemnización por la pérdida de los mismos; ni la recuperación de los costes arbitrales soportados. 


\section{OBLIGACIONES POSTERIORES A LA ACEPTACIÓN DEL ÁRBITRO}

\subsection{Obligaciones generales}

Los árbitros tienen la necesaria autonomía para decidir, a tenor de las circunstancias concurrentes en cada caso, si deben resolver la cuestión de competencia como algo previo al procedimiento arbitral con un laudo parcial o si por el contrario debe resolverlo en el laudo que ponga final al arbitraje, aunque la experiencia arbitral aconseja esta segunda opción, puesto que no debemos olvidar que los diferentes laudos que se emitan en un mismo procedimiento arbitral no pueden corregirse ni contradecirse entre sí, puesto que tienen sustantitividad propia como decisiones arbitrales, que pueden ser impugnadas en los términos y con las consecuencia que prevé la NLAB para el caso de un único laudo que pone fin al arbitraje. Por lo tanto, una resolución interlocutoria o laudo parcial que resuelva la cuestión de competencia corre el riesgo de entrar en incongruencia con el futuro laudo que podemos denominar «final», en el que es probable que los árbitros hagan referencia e interpreten hechos coincidentes, con el riesgo de conclusiones no exactamente idénticas. Por lo tanto, salvo en el caso de que la decisión sea estimatoria, lo que lógicamente pone fin al arbitraje, resulta lo más aconsejable que el procedimiento arbitral siga su curso, sustanciándose paralelamente el incidente competencial, que será resuelto definitivamente en un único laudo.

Desde esta perspectiva, la responsabilidad del árbitro únicamente podrá derivarse de una estimación de la cuestión de competencia que resulte manifiestamente temeraria, dolosa o fruto de la mala fe, es decir, dolosa o gravemente negligente; o bien de su desestimación irrazonada, que pueda ser incardinada dentro de una de las tres vertientes de la responsabilidad antes comentadas.

Quien reclame la responsabilidad del árbitro debe probar la realidad y valoración de los daños y perjuicios ${ }^{87}$ que argumenta, que los mismos se han derivado de una actuación del árbitro, así como el grado de intencionalidad de esa actuación. En conclusión, los daños y perjuicios únicamente pueden encontrar su fundamento en los cos-

${ }^{87}$ En ningún caso cabría la posibilidad de que prosperara la reclamación de responsabilidad contra un árbitro que hubiera estimado una cuestión de incompetencia -y posteriormente el Tribunal Superior de Justicia hubiera anulado su decisión arguyendo que los daños y perjuicios vienen constituidos por no haber podido acceder a la concesión de su petitum dentro del un procedimiento arbitral, valorando los mismos en la citada cuantía. 
tes a los que la parte se haya visto obligada incurrir en relación directa con las consecuencias de la desestimación de la cuestión de competencia, que fundamentalmente vendrán asociados a las propias costas de un arbitraje que deviene inútil para las partes, ya que al ser anulado el laudo queda abierta la vía jurisdiccional para la resolución en la misma de la litis en un principio arbitral. Sólo muy excepcionalmente será posible probar la realidad de los daños y perjuicios que se hayan derivado para las partes como consecuencia de la demora en la solución de la litis que ha supuesto agotar todo el procedimiento arbitral, máxime cuando dentro del mismo tienen cabida la solicitud de medidas cautelares.

\subsection{Obligación de fijar y comunicar a las partes unos honorarios y gastos de arbitraje justos}

Antes de centrarnos en cómo se concreta esta obligación en la NLAB, es interesante, proponiendo una interpretación analógica de los honorarios del abogado y del árbitro, entender la trascendencia de los servicios prestados desde la perspectiva de nuestra tradición romanística. Así, FERNÁNDEZ DE BUJÁN, F. ${ }^{88}$, señala: «Entendiendo que los servicios intelectuales prestados no solo son fruto de la actividad profesional desplegada en el concreto caso que se presta sino de la sabiduría y del conocimiento en la concreta parcela del saber que el profesional tenga -al no ser solamente un práctico sino también un estudioso, se considera que el beneficio obtenido por el cliente no es exactamente medibles o evaluable en dinero. Por ello la retribución, aun la pactada expresamente, se entiende como una contraprestación que no puede ser un reflejo exacto y prestación del servicio realizado.

Además una nueva diferencia distingue al mandato retribuido de un abogado, del servicio prestado por un operario en la realización del servicio material. No cabe hablar de sinalagma en cuanto a una interdependencia estricta de las prestaciones debidas. Así, en la locatio conductio operarum si el locator realiza la prestación del servicio pactado es, exclusivamente, porque el conductor le abona la renta pactada. En el mandato si el abogado realizar la tarea de defensa de su cliente lo hace en el desempeño de un officium que a pesar de realizarse pensando la retribución, no se realiza, exclusivamente, por causa del dinero que va a obtener. Por ello, la actividad del abogado, como mandatario, no tiene como obligación correlativa la obligación

${ }^{88}$ FERNÁNDEZ DE BUJÁN, Federico: Justicia y ética de la abogacía (coordinado por Miguel Grande Yáñez). Dykinson. 2007, págs. 50 y 51. 
del cliente, como mandante, de abonar los honorarios convenidos. Así la condición de abogado, como la de médico o la de profesor, eran en el mundo antiguo, algo más que meras y simples profesiones en las que toda meta para profesional se reducía a cobrar la retribución pactada.

El servicio se prestaría así desde la actividad intelectual que, por definición, y difícilmente valuable económicamente y, además se hace por causa de los honorarios, pero no solo por los honorarios, sino también por la prestación misma de un servicio que, al tiempo de beneficiar a quien lo solicita, enriquece y complace a quien lo presta. Se desvincula por ello, Roma, de una hiperprofesionalización de los servicios profesionales liberales, considerando que son demasiado importantes para el bien social, como para reducirlos a un simple esquema de interdependencia de prestaciones de carácter meramente económico.

Cuando el potencial árbitro recibe una propuesta de nombramiento, a partir de la misma, ya sea un arbitraje ad hoc o un arbitraje administrado, debe preparar una propuesta de honorarios para hacérsela llegar a la parte proponente. Asimismo, tiene la posibilidad, antes de incurrir en la hipotética responsabilidad de incumplir el encargo, de solicitar provisiones de fondos a las partes que le garantice el cobro de sus honorarios y gastos y de los gastos de administración del arbitraje, con anterioridad a su aceptación como árbitro, condicionando la misma al pago de la citada provisión que, insistimos, cubre ambos conceptos ${ }^{89}$.

Con sujeción a lo acordado por las partes, los árbitros se pronunciarán en el laudo sobre las costas del arbitraje, que incluirán los honorarios y gastos de los árbitros y, en su caso, los honorarios y gastos

${ }^{89}$ Vid. Sentencia de Audiencia Provincial, Castellón, de 19/09/1996; sentencia de Audiencia Provincial, Madrid, de 21/10/1991; sentencia de Audiencia Provincial, Madrid, de 19/04/1992; sentencia de Audiencia Provincial, Madrid, de 10/11/1992; sentencia de Audiencia Provincial, Madrid, 17/2003 de 11/12/2003; sentencia de Audiencia Provincial, Zaragoza, de 06/09/1991; sentencia de Tribunal Superior de Justicia, Cataluña, Sala de lo Civil y Penal, 74/2013 de 30/12/2013; sentencia de Tribunal Supremo, Sala de lo Civil, 952/2001 de 18/10/2001; sentencia de Tribunal Supremo, Sala de lo Civil, de 14/07/1986; sentencia de Audiencia Provincial, Madrid, 251/2011 de 24/05/2011; sentencia de Tribunal Superior de Justicia, Comunidad de Madrid, Sala de lo Civil y Penal, 65/2013 de 30/07/2013; sentencia de Tribunal Supremo, Sala de lo Civil, de 19/02/1944; sentencia de Tribunal Supremo, Sala de lo Civil, de 13/04/1962; sentencia de Tribunal Supremo, Sala de lo Civil, de 01/12/1986; sentencia de Tribunal Supremo, Sala de lo Civil, de 02/02/1990; sentencia de Tribunal Supremo, Sala de lo Civil, de 29/11/1996; sentencia de Tribunal Supremo, Sala de lo Civil, 1159/2000 de 15/12/2000; sentencia de Tribunal Supremo, Sala de lo Civil, 355/1998 de 310/1998. 
de los defensores o representantes de las partes, el coste del servicio prestado por la institución administradora del arbitraje y los demás gastos originados en el procedimiento arbitral.

Si una parte -o ambas- están descontentas con las costas fijadas por el árbitro, en primer lugar debieran haberlo manifestado al inicio del procedimiento arbitral y una vez emitido el laudo, instar la acción de impugnación apoyada en el motivo de unas costas excesivas, lo que se considera un incumplimiento de los principios que rigen el procedimiento arbitral, que en caso de ser apreciado únicamente supondrá la anulación parcial del laudo, es decir, afectaría únicamente a la parte dispositiva del misma en la que se determina su composición, cuantía y distribución.

Obviamente, de cara a determinar si los honorarios arbitrales pudieren ser injustos, es clave tomar en consideración estas dos premisas:

A) No existe entre las partes y los miembros del Colegio Arbitral la relación bilateral incardinable dentro del artículo 1.544 del Código Civil, sino que esa relación nace del convenio arbitral que tiene el carácter de contrato de mandato atípico, mixto y multilateral.

B) Hay que comprobar la posible existencia de actuaciones o documentos que demuestren indubitadamente que exista un pacto o aceptación expresa e inequívoca por las partes de la cantidad a abonar en concepto de honorarios y gastos de los árbitros y que dicho acuerdo haya sido reconocido y respetado por ambas partes a lo largo de todo el procedimiento arbitral.

En conclusión, después de lo expuesto, podemos afirmar que no existen unos honorarios arbitrales que sean justos e injustos per se, sino que su bondad deberá siempre tomarse en consideración sobre la base de que hayan sido aceptados o no por las partes. Esa aceptación se produce de forma tácita en el caso del arbitraje administrado, puesto que todas las entidades arbitrales cuentan con una tabla financiera que marca los baremos aplicables a cada arbitraje en atención a la cuantía en controversia; y esa primera aceptación se convierte después en una aceptación específica cuando la institución arbitral calcula al caso concreto la cuantía de los honorarios arbitrales y de los gastos de administración del arbitraje y solicita una provisión de fondos a las partes en litigio. Es importante reseñar que será en este momento cuando el cálculo sea detallado y preciso, puesto que si se ha producido reconvención de la contraparte, el quantum litis se habrá incrementado y por ende también lo habrán hecho los honorarios 
de los árbitros y los gastos de administración, que se calculan proporcionalmente a la citada cuantía.

Obviamente, en ese momento las partes están aceptando esa cuantía y salvo que expresamente se opongan a la misma de forma fehaciente, aunque presten la provisión de fondos, no podrán posteriormente atacar las costas arbitrales que serán parte del fondo del laudo, en virtud de la restricción que impone el artículo 6 NLAB. No obstante, podemos defender que tendrían las partes una última oportunidad de expresar su descontento con las costas arbitrales a través del recurso de aclaración, solicitando en el mismo que se corrija el cálculo que a su criterio es erróneo. Incluyendo tal solicitud en el citado recurso aclaración, podría ser instado ese motivo por la parte en la acción de impugnación del laudo en lo que se refiere al punto específico y parcial de las costas arbitrales y de ser apreciado, sería la base para reclamar al árbitro el importe de los honorarios cobrados en exceso, tomando como referencia la sentencia del Tribunal Superior de Justicia $^{90}$. Por lo tanto, el hecho factual sería el cálculo de las costas arbitrales y/o de su imputación a las partes, en desacuerdo con lo pactado en el arbitraje; el daño causado, el diferencial entre el importe recogido en el fundamento anulado del laudo relativo a las costas arbitrales y el importe correcto; y el nexo causal entre el hecho factual y el daño es la apreciación de esa nulidad por parte del Tribunal Superior de Justicia. El elemento que falta para completar la exigencia de responsabilidad es la intencionalidad, que en este caso debemos reputar como dolosa ${ }^{91}$ o como de negligencia grave, puesto que como hemos señalado, al menos una vez a lo largo del procedimiento la parte reclamante ha expuesto sus argumentos explicando el error de cálculo cometido por el árbitro -posteriormente reconocido por el Tribunal Superior de Justicia- y éste no lo ha enmendado, dejando la redac-

${ }^{90}$ Sin embargo, la anulación parcial del laudo en lo referente a la decisión de los árbitros no puede considerase como un título constitutivo y probablemente ni siquiera declarativo, salvo que el Tribunal Superior de Justicia hubiera bajado al detalle del cálculo de cuáles eran las costas arbitrales correctas a tenor de lo pactado. Por ello, la parte reclamante debiera acudir al Juzgado de Primera instancia para solicitar el resarcimiento.

${ }^{91}$ Podríamos hablar especialmente de dolo en el caso de que el árbitro decidiera realizar una prueba a la que ambas partes se opusiera, imputando su coste dentro de las costas arbitrales. Un ejemplo pudiera ser un informe de perito independiente nombrado por el árbitro, para que conociera de una materia sobre la que cada parte hubiera aportado un informe de su propio perito. Por mucho que le pudiera resultar más cómodo al árbitro contar con ese tercer informe, si ambas partes se oponen al mismo y no quieren asumir su coste, normalmente elevado, el árbitro no puede imponer su voluntad y obligar a que las partes finalmente lo asuman a través de las costas arbitrales. 
ción final del laudo en el punto relativo a esa materia contaminado con el error.

En el caso del arbitraje ad hoc lógicamente no existe una tabla que permita a priori conocer a las partes los honorarios del árbitro y los posibles gastos de administración, por lo que será preceptivo que el árbitro prepare un presupuesto para las partes, y normalmente condicionará su propia aceptación del nombramiento como árbitro a la aceptación del citado presupuesto. Igualmente lo habitual es que solicite una provisión de fondos. En cualquier caso, las reflexiones realizadas en el párrafo anterior son plenamente aplicables a éste.

Dado que resulta inimaginable una situación en la que un procedimiento arbitral se desarrolle sin haber fijado los árbitros y las partes el contenido económico de la prestación de los servicios del árbitro, hemos de concluir que, en definitiva, la problemática con respecto a las costas arbitrales no viene motivada por una discusión teórica sobre si los honorarios son altos o bajos o por cómo se distribuyen los mismos entre las partes; sino por las posibles divergencias empíricas en el cálculo de los citados honorarios y demás gastos del procedimiento arbitral ${ }^{92}$, así como en la imputación de los mismos a las partes, que realice el árbitro y que no se compadezca literalmente con lo previsto por las partes y aceptado por el árbitro.

\subsection{Obligación de determinar y conducir el procedimiento y cumplir los principios y formalidades ${ }^{93}$}

\subsubsection{Principios esenciales según la NLAB: Audiencia, contradicción e igualdad}

En el procedimiento arbitral deben observarse escrupulosamente los principios esenciales por los que ha de regirse, como son el de ro-

\footnotetext{
${ }^{92}$ Se han debido de fijar los criterios no solamente para los honorarios y los gastos de administración del arbitraje, sino también sobre todo lo relativo a los gastos derivados de las pruebas, ya sean de confesión, testificales, periciales, fijando las normas de quien sufraga los costes y hasta que cuantía, etc.. De hecho, puesto que la norma habitual en el arbitraje es que cada parte sufrague las pruebas qué propone, ello tiene el positivo efecto de desanimar tácticas procesales tendentes a enlentecer el proceso basadas en la propuesta de múltiples y complejas pruebas, ya que incrementar el coste sensiblemente para la parte proponente.

${ }^{93}$ Vid. Sentencia de 6 de septiembre de 1991 de la Audiencia Provincial de Zaragoza; Sentencia de 21 de octubre de 1991 de la Audiencia Provincial de Madrid; Sentencia de 19 de septiembre de 1996 de la Audiencia Provincial de Castellón; Sentencia 17/2003 de 11 de diciembre de la Audiencia Provincial de Madrid; Sentencia n. ${ }^{\circ}$ 4/2013 del Tribunal Superior de Justicia de Castilla La Mancha, de 10 de octubre de 2013.
} 
gación, bilateralidad, contradicción, igualdad de partes, congruencia y proscripción de cualquier situación de indefensión, todos los cuales se plasman y quedan recogidos en los tasados motivos de anulación del laudo, cuya interpretación debe ser estricta, siéndole de aplicación la doctrina constitucional sobre interpretación de disposiciones procesales en el sentido más favorable para la efectividad del derecho a la tutela judicial efectiva consagrado en el artículo 24.1 CE, evitando formulismos enervantes y obligando a la ponderación del vicio procesal advertido con la sanción al cierre del proceso y del acceso a la justicia que del mismo se pudiera derivar, debiendo en dicha ponderación atenderse a la entidad del defecto y a su incidencia en la consecución de la finalidad perseguida por la norma infringida, y su trascendencia para las garantías procesales de las demás partes del proceso, teniendo siempre presente que, la indefensión proscrita en el artículo $24 \mathrm{CE}$ no nace de la simple infracción de las reglas procesales sino de la privación del derecho a alegar y a demostrar en el procedimiento los propios derechos e intereses, o para replicar las posiciones contrarias en el ejercicio del principio de contradicción

Los precitados principios de audiencia y contradicción no significan otra cosa que la posibilidad de la parte de ser oída y formular alegaciones y pruebas en defensa de su derecho (audiencia), y, la garantía o cautela encaminada a que las partes pueden efectuar un auténtico debate, con la posibilidad de formular sus contestaciones o réplicas frente a las posiciones del contrario (contradicción). Y para que pueda apreciarse una posible indefensión contraria al artículo 24.1 CE, es necesario que esta sea material y no meramente formal, lo que implica que el pretendido defecto haya supuesto un perjuicio real y efectivo para la parte en sus posibilidades de defensa y que la indefensión padecida no sea imputable a la propia voluntad o a la falta de diligencia del interesado; no procediendo, en ningún caso, la retroacción de las actuaciones cuando el resultado del litigio hubiera permanecido inalterable de no haberse producido la omisión denunciada.

Es importante enfatizar que el incumplimiento de cualquier de los anteriores principios no puede ser entendido como vulneración del orden público a los efectos de la acción de impugnación del laudo, sino que cuentan con motivos de anulación específicos.

El incumplimiento de los citados principios fundamentales del proceso arbitral, por parte de él árbitro, en la mayor parte de los casos, al ser denunciados por la parte en la impugnación del laudo como funda- 
mento de la misma, a tenor de lo previsto en la NAL, conducirán a la anulación del laudo y por ende a la frustración del fin del arbitraje ${ }^{94}$.

Como hemos analizado en detalle en los epígrafes 3.2.3 y 3.2.3.1, existen muchas situaciones procesales en las que el árbitro puede cruzar la línea roja e incumplir alguno o varios de estos principios, por lo que resulta imposible hacer una enumeración exhaustiva de todas esas posibles situaciones. Lo que es verdaderamente importante para el buen árbitro es entender, tal y como hemos tratado de mostrar en esta obra, el verdadero sentido que estos principios tienen con respecto al arbitraje y ponderar todas sus actuaciones sobre la base de los mismos para evitar que ninguna de ellas suponga indefensión, inaudición o falta de contradicción para una de las partes.

También es importante entender que siendo los principios fundamentales del procedimiento arbitral, la obligación de su cumplimiento es absoluta sin que quepa relajarse considerando que un mínimo incumplimiento de los mismos podrá quedar impune al no tener un efecto en el laudo, supuestamente. Ese planteamiento es contrario a la definición del arbitraje, en el que prima la autonomía de la voluntad de las partes y como garantía a las mismas se establece un procedimiento con unas características garantistas que no deben ser incumplidas y que de hecho son las que fundamentan una lista tasada de motivos de anulación del laudo, que en realidad se asemeja a una revisión de sentencia.

Una vez descritos cuales son los hechos factuales que pudieren dar origen a la responsabilidad del árbitro, debemos analizar el grado de intencionalidad de la conducta del mismo, puesto que únicamente si concurre dolo o negligencia grave podrán serle exigencias responsabilidades. Como ya hemos comentado, el onus probandi recae en la parte reclamante y eso hace que sea muy complicado poder probar conductas movidas por el dolo, salvo que hayan sido enormemente groseras en su ejecución. Puede ayudar en la argumentación el hecho de haber sido recusado el árbitro -por ser tachado de parcial- al que se le acusa de dolo y que éste hubiera rechazado tal recusación, ya que ello introduce una conexión lógica con la conducta dolosa.

En cuanto a la negligencia grave, podemos encontrarla en conductas del árbitro que impliquen una dejación de su especial diligencia,

${ }^{94}$ Vid. Sentencia del Tribunal Supremo de 19 de febrero de 1944; Sentencia del Tribunal Supremo de 14 de julio de 1986; Sentencia del Tribunal Supremo de 11 de diciembre de 1987; Sentencia del Tribunal Supremo de 2 de febrero de 1990; Sentencia del Tribunal Superior de Justicia de la Comunidad de Madrid, n. ${ }^{\circ}$ 65/2013, de 30 de julio de 2013. 
superior a la exigida a un buen padre de familia, que no sea enturbiada por la supuesta complejidad de una decisión jurídica. A simple modo de ejemplo, el árbitro que admita a una de las partes la posibilidad de hacerle llegar un escrito adicional de conclusiones tras haber presentado ambas partes sus respectivos escritos de conclusiones conculca los principios precitados y es una negligencia grave porque cualquiera que asuma la condición y responsabilidad de árbitro está obligado a saber que no deben contar las partes con posibilidades desequilibradas a la hora de expresar sus razonamientos jurídicos y su interpretación de los hechos.

Otro caso, citado a modo de ejemplo, que podría calificarse de negligencia grave, vendría dado por no notificar un informe pericial recibido por el árbitro en el mismo plazo a ambas partes, dejando sin tiempo material a una de ellas para su revisión y comentario en la audiencia pertinente o en la ratificación del perito. Y es que cualquier árbitro tiene la obligación de saber que las notificaciones, en todo el procedimiento arbitral, deben hacerse -o por lo menos intentarse con toda la diligencia precisa- de forma simultánea a ambas partes. De hecho, ni siquiera podría liberarse de su responsabilidad en el arbitraje administrado, en el que sea la entidad arbitral quien se encargue físicamente del registro y notificaciones, ya que la misma actúa como un mero ejecutor, cómo lo haría un secretario del Colegio Arbitral.

Es importante enfatizar que las partes pueden reclamar la responsabilidad a la entidad arbitral a la que hayan encomendado el arbitraje pero no por actos concretos realizados por la misma una vez iniciado el arbitraje que sean acciones instrumentales, tales como las notificaciones, puesto que la base de la reclamación que prescribe la NLAB se basa en un error in eligendo de la entidad arbitral con respecto a los árbitros elegidos para el procedimiento, quienes con su actuación han hecho peligrar el buen fin del mismo. Por contra, sí es admisible plantear la posibilidad de que el árbitro que haya sido demandado por la parte, acusado de negligencia grave en las comunicaciones que físicamente han sido realizadas por la entidad arbitral, demandé a su vez a está repitiendo contra ella la indemnización que le pudiera venir impuesta. Es decir, así como la entidad arbitral puede repetir contra el árbitro por la indemnización a la que pudiera ser condenada por el citado error in eligiendo, los árbitros a su vez podrán hacerlo contra la entidad arbitral, exclusivamente en relación a aquellas acciones que correspondan a la esfera meramente operativa de la entidad arbitral, una vez iniciado el arbitraje. 
Tras la intencionalidad, debemos ahora centrarnos en la existencia de un daño cierto y cuantificable. Y éste, en todos los casos, será la anulación del laudo que venga motivada por el incumplimiento de alguno de los citados principios esenciales, puesto de manifiesto por la parte reclamante en la acción de impugnación, y que previamente tenía la obligación de manifestar en el procedimiento arbitral a tenor de lo previsto en el artículo $6 \mathrm{NAL}$, con el fin de que no se le cerrara la puerta de la acción de impugnación. La anulación del laudo trae consigo la frustración del fin del arbitraje y la necesidad para las partes de acudir a un nuevo procedimiento arbitral o a la jurisdicción ordinaria, dependiendo de lo que disponga el convenio arbitral que las partes se hubieran otorgado. Por lo tanto, el importe del daño se corresponde con las costas arbitrales. Es decir, que aunque se hubiera producido el hecho factual, incluso en el mayor grado de intencionalidad, ergo, que fuera doloso, si ello no conduce a la anulación del laudo no puede ser objeto de reclamación, ya que no existe un daño directo causado por el mismo.

El último elemento a considerar en el análisis de la responsabilidad civil del árbitro es el nexo causal entre el daño y el hecho factual. En este caso la identificación del mismo es sencilla, puesto que el hecho factual debe constituir necesariamente el motivo de la acción de impugnación que finalmente suponga la anulación del laudo.

\subsubsection{Principios técnicos dimanantes de la NLAB}

Vamos a centrar nuestra atención en determinar su impacto en la responsabilidad que pudiere serle exigida a los árbitros por su incumplimiento.

En nuestra opinión, la correcta interpretación del principio de libertad formal ${ }^{95}$ significa que no se podrán depurar responsabilidades al árbitro en el desarrollo del procedimiento arbitral más allá del cumplimiento estricto de los principios de audiencia, contradicción e igualdad, de hecho limitando el alcance en la interpretación de los mismos al tratar de evitar cualquier enervación de los formalismos del proceso, prestando atención a la realidad objetiva de lo sucedido y no a la apariencia de lo sucedido. Por ende, no resulta posible dedu-

${ }^{95}$ Vid. Sentencia del Tribunal Supremo de 21 de enero de 1961; Sentencia del Tribunal Supremo de 25 de mayo de 1979; Sentencia del Tribunal Supremo de 1 de diciembre de 1986; Sentencia del Tribunal Supremo de 13 de noviembre de 1987; Sentencia 5/2014 del Tribunal Superior de Justicia de Andalucía de mayo de 2014. 
cir responsabilidades directas de este principio en relación a los árbitros.

Lo mismo se puede decir del principio de secreto de las actuaciones ${ }^{96}$ que viene a limitar el alcance de los principios esenciales aplicables al procedimiento arbitral, señalando que en nada se ven perjudicados los mismos si, por ejemplo, el Colegio Arbitral no levanta acta de sus deliberaciones y votaciones, considerándolas secretas; del principio de incontingencia de la asistencia letrada ${ }^{97}$, al señalar que en nada se ven perjudicados los mismos si una de las partes decidiera asistirse de representación letrada y la otra no, ya que no ello no causa indefensión alguna, así como tampoco puede en ningún caso la parte que haya optado por representación letrada escudarse en posibles errores cometidos por la misma en la ejecución de su mandato profesional ${ }^{98}$; del principio de predominio de la escritura frente a la oralidad, señalando que en nada se ven perjudicados los mismos si el árbitro, dentro de los límites de la voluntad del las partes y del reglamento, de la entidad arbitral, si fuera un arbitraje administrado, optara por un procedimiento en que el que predominara el elemento escrito en todas las interacciones con las partes, testigos y peritos; del principio de no preclusión de las actuaciones ${ }^{99}$, señalando que en nada se ven perjudicados los mismos si se deja en manos de los árbitros la decisión razonada de la procedencia de la ampliación o modificación de las pretensiones iniciales.

En todos los casos anteriores no resulta posible deducir responsabilidades directas de los citados principios en relación a los árbitros.

Con respecto al principio de impulso de oficio del procedimiento ${ }^{100}$, decir que en nuestra opinión no se pueden inferir responsabilidades directas del mismo de cara a los árbitros, sino que las mismas

${ }^{96}$ Vid. Sentencia n. ${ }^{\circ}$ 9/2014 del Tribunal Superior de Justicia de Cataluña, de 6 de febrero de 2014; y sentencia n. ${ }^{\circ}$ 53/2014 del Tribunal Superior de Justicia de Cataluña, de 24 de julio de 2014.

${ }^{97}$ Vid. Sentencia n. ${ }^{\circ}$ 8/2014 del Tribunal Superior de Justicia de la Comunidad de Madrid, de 19 de febrero de 2014.

${ }^{98}$ No obstante, es importante señalar que de cara al fluido devenir del procedimiento arbitral resulta muy conveniente que las partes se representen por medio de abogados - preferentemente juristas con conocimiento de la material arbitral-, ya que ello permitirá que se alcancen con mayor facilidad y garantías los resultados deseados para el arbitraje, que no son otros que un laudo que resuelva la controversia, obviando enfrentamientos personales entre las partes que no empezcan, como señala GONZÁLEZ SORIA, para el futuro desenvolvimiento de sus relaciones mercantiles.

${ }^{99}$ Vid. Sentencia del Tribunal Supremo de 8 de febrero de 1989.

${ }^{100}$ Vid. Sentencia n. ${ }^{\circ}$ 55/2014 del Tribunal Superior de Justicia de la Comunidad de Madrid, de 14 de octubre de 2014. 
vendrán dadas por la posible extemporaneidad del laudo, a cuyo tratamiento nos remitimos. Es decir, consideramos que únicamente será relevante el incumplimiento de este principio a efectos de responsabilidad arbitral si el laudo se dictara fuera de plazo, debiendo entonces estarse a las consecuencias que hemos identificado para ese supuesto en el epígrafe 3.2.4.6 de esta obra.

El principio de aportación de parte está íntimamente ligado al artículo 38.3 NAL, que señala que «Los árbitros también ordenarán la terminación de las actuaciones cuando... los árbitros comprueben que la prosecución de las actuaciones resulta innecesaria o imposible», siendo el reverso del principio de impulso de oficio del procedimiento. Así pues, el árbitro debe impulsar el procedimiento, pero ello no significa suplir por completo la actuación debida de las partes en el proceso, por lo que si las mismas llegan a un punto tal de inacción, el árbitro se verá forzado a terminar las actuaciones, aceptando la frustración del arbitraje, sin que de ello se puedan derivársele responsabilidades, ya que tal terminación ha venido obligada por el comportamiento procesal de las partes. Nuestra sugerencia en ese caso es que el árbitro dicte una resolución en la que resuelva la terminación de las actuaciones y de forma razona explique las causas que le han llevado a ello, así como detalle en el mismo el cálculo e imputación de las costas arbitrales efectivamente devengadas.

Por su parte, el principio dispositivo nos lleva a un caso excepcional en relación a la obligación de «laudar bien», que se produce cuando las partes, en medio del procedimiento arbitral, deciden de mutuo acuerdo desistir del procedimiento arbitral y le solicitan al árbitro que dicte un lado cuyo contenido sea íntegramente el acuerdo alcanzado por las partes. A tenor de lo previsto en la NLAB, el árbitro podría llegar a negarse, y si bien la norma no explica los motivos para ello, la lógica nos dice que deberán venir fundamentados por el hecho de que el citado acuerdo contravenga normas imperativas o presente desequilibrios entre las partes que sean contrarios a la teoría general de los contratos.

Sin embargo, este es un terreno delicado para el árbitro, ya que si en el arbitraje tenemos muy claro que prima la autonomía de la voluntad de las partes, no debiera pretender constituirse el árbitro en una figura revisora, simulando el papel del Tribunal Superior de Justicia. Es decir, si la misión del árbitro es decidir un litigio y las partes son capaces de ponerse de acuerdo para resolverlo, el árbitro deberá respetar tal decisión y recoger la misma en una resolución qué por 
imperio de la ley es considerada como un laudo arbitral y, por ende, sujeta a la revisión del Tribunal Superior de Justicia y que dependerá del auxilio jurisdiccional para su ejecución.

Lógicamente, podremos suponer que un laudo de esas características no será impugnado en anulación por las partes, ya que son ellas precisamente las que han conformado su contenido, por lo que devendrá firme y definitivo, lo que elimina cualquier posibilidad de reclamación contra el árbitro por anulación del citado laudo. Y si después las partes se encuentran con problemas para solicitar su ejecución ante un Juzgado de Primera Instancia o para inscribir en el correspondiente registro parte de sus disposiciones, tales hechos no podrán ser imputados al árbitro, puesto que son las partes las completas responsables de la estructura y contenido del laudo. No obstante, nuestra sugerencia para el árbitro, de cara a salvaguardar aún más su responsabilidad, es que en los casos en los que aprecie posibles problemas de futuro en el contenido y forma del acuerdo de desistimiento por resolución de la litis que le propongan las partes, comunique a estas de forma fehaciente sus reflexiones y sugerencias de cara a la redacción del citado acuerdo de desistimiento que debe convertirse en el cuerpo del laudo. Asimismo, en cumplimiento de lo previsto en la NLAB, debiera el árbitro introducir obligatoriamente en el citado laudo el detalle del cálculo de las costas arbitrales, sobre cuya distribución también podrían haber pactado las partes, siendo vinculante para el árbitro. El árbitro también debiera ser muy vigilante de que el contenido dispositivo del laudo pudiera afectar negativamente a terceros ajenos al arbitraje, llegando a tener que afrontar una exigencia de responsabilidad extracontractual.

Por contra, entendemos que el árbitro sí podría incurrir en responsabilidad si se negara a emitir el laudo que le solicitan las partes, y para que la misma no le fueran aplicable debería fundamentar de forma muy detallada el porqué de su negativa, que en ningún caso podría estar basada en su interés porque el procedimiento arbitral se completara hasta el final y así poder cobrar la totalidad de los honorarios. Ese sería un caso claro de dolo, en el que el daño cierto cuantificado sería el total de los costes del arbitraje, ya que cuando el laudo se hubiera emitido por el árbitro sin recoger el contenido de las partes, éstas instarían su anulación, que se producirá por nulidad del convenio arbitral por falta de voluntad concorde de las partes y se verían abocadas a un nuevo procedimiento, arbitral o judicial, para 
poder contar con un título ${ }^{101}$ declarativo de su acuerdo que pueda ser ejecutable.

El nexo causal en este caso es la decisión de él árbitro de no emitir un laudo con el contenido acordado por las partes sino proceder a continuar el procedimiento arbitral hasta emitir un laudo basado en su exclusivo poder decisional.

\subsubsection{Principio de libertad formal}

El procedimiento es libre y de acentuada flexibilidad, pues no tiene que sujetarse a formas legales ni acomodarse a pautas de derecho material en cuanto al fondo, cumplida la exigencia que por imperativos del principio de contradicción, también operante en su ámbito, debiendo ajustarse únicamente a las previsiones específicas de la NAL y, en su caso, del reglamento de la institución arbitral que administre el arbitraje.

\subsubsection{Principio del secreto de las actuaciones}

La razón de ser del secreto de las deliberaciones del colegio arbitral descansa en la necesidad de mantener la igualdad de las partes en el proceso y de resguardar su derecho de defensa, tanto como en la de preservar la independencia de los propios árbitros, además de constituir una consecuencia inevitable del deber de confidencialidad de las informaciones contenidas en las actuaciones arbitrales, cuya infracción, al regularse entre los principios del procedimiento arbitral, podría dar lugar a la nulidad del Laudo conforme al apartado d) del artículo 41.1 LAB.

\subsubsection{Principio de incontingencia de asistencia letrada}

No existe precepto alguno, por razón del procedimiento y su naturaleza, que exija o siquiera refiera la intervención de Letrados y Procuradores en tramitación del procedimiento arbitral, precisamente en aras a

${ }^{101}$ Curiosamente, como señala D’ORS, ALVARO. Vid. «Titulus». Anuario de Historia del Derecho español, número 57, Madrid 1953, Álvaro D’Ors, pág. 23, «Un concepto aparentemente tan romano como el de título en el sentido de fundamento o causa jurídicos, el justo título, resulta así extraño los romanos de la época clásica; sería, como tantas otras recibirás por derecho medieval y moderno, una creación de la época del Bajo Imperio, de esa época que se puede llamar con razón una «pre Edad Media, una evidente continuidad histórica que nos impone una indeclinable solidaridad científica entre romanistas y medievistas». 
dotarlo del carácter autónomo e independiente que justifica su existencia. En consecuencia, cada parte es libre de nombrar o no Letrado que le defienda, y lleve a cabo todas y cada una de las actuaciones que la ley atribuye siempre y de forma exclusiva a «las partes», esto es, personas físicas o jurídicas a las que afecta la controversia y forman parte del procedimiento, sin que los árbitros estén obligados a efectuar indicación alguna al respecto, sino, simplemente, tratar a las partes con igualdad y darle a cada una suficiente oportunidad de hacer valer sus derechos.

\subsubsection{Principio del impulso de oficio}

El árbitro está obligado a penetrar en la dirección del procedimiento, más allá de limitarse a actuar según las proposiciones de las partes. Dentro de este principio de impulso de oficio se incluyen los deberes instrumentales del árbitro, que se integran en el deber general de conducir al procedimiento. Por ejemplo, deberá notificar su aceptación a las partes para promover el inicio del procedimiento; constituir el colegio arbitral; nombrar, en su caso el Secretario, nombrar el Presidente; solicitar el auxilio judicial para la práctica de aquellas pruebas que lo precisaren; repetir las pruebas practicadas si se incorporara válidamente un nuevo árbitro al colegio arbitral salvo que se considerara innecesario; acordar potestativamente oír de nuevo a las partes después de practicar las pruebas, etc.. Y, en general, realizar adecuadamente todas las notificaciones precisas dentro del procedimiento arbitral.

\subsubsection{Principio de predominio de la escritura frente al de oralidad}

Aunque se recoge cierta libertad formal derivada de la autonomía de las partes, la NLAB prima la escritura sobre la oralidad, como vemos en los artículos 5, 6, 28.1, 30.1, 30.3, 37.3, y 37.4.

\subsubsection{Principio de aportación de parte}

La NLAB lo recoge en sus artículos 5, 6, 25 y 30.

\subsubsection{Principio de preclusión de las actuaciones}

La preclusión de los plazos queda atemperada si las partes así lo acuerdan y los árbitros consideran que es procedente al no ser excesi- 
vamente extemporánea la modificación o ampliación de la demanda o contestación.

\subsubsection{Principio dispositivo}

El principio dispositivo inspira la propia institución arbitral y se concreta en que si durante las actuaciones arbitrales las partes llegan a un acuerdo que ponga fin total o parcialmente a la controversia, los árbitros darán por terminadas las actuaciones con respecto a los puntos acordados y, si ambas partes lo solicitan y los árbitros no aprecian motivo para oponerse, harán constar ese acuerdo en forma de laudo en los términos convenidos por las partes.

\subsection{Medidas cautelares}

En el caso de las solicitadas por las partes al Juzgado competente, la responsabilidad de los árbitros en relación a las medidas cautelares es muy limitada, ya que los mismos no son responsables de solicitarlas o de pedir que sean retiradas. Únicamente habrán de ser conscientes de las mismas y coordinar los efectos de las mismas con los efectos que pretendan que despliegue su laudo. En conclusión, resulta muy difícil imaginar un escenario en el que el árbitro pueda ser encontrado responsable, a los efectos civiles que venimos comentado en esta obra, en relación con las medidas cautelares solicitadas por las partes ${ }^{102}$.

De hecho, en puridad jurídica, el árbitro debe entender esas medidas cautelares como un "auxilio jurisdiccional», e integrar las mismas fácticamente en el procedimiento, es decir, como un fundamento de hecho más. Huelga decir que, aunque en ningún caso se ve obligado por una decisión estimatoria de las medidas cautelares por parte del Juez de Instancia, al requerirse un "fumus boni iuris» para su concesión, es conveniente que el Arbitro estudie los fundamentos del Auto en el que las mismas se aprueben, con el fin de ayudarle a mejorar su visión global de los hechos de la res litis.

Supuesto muy diferente es el de las medidas cautelares solicitadas al árbitro, pues se ve obligado a tomar decisiones con impacto económico en los inicios del procedimiento, cuando lo máximo que puede

102 Vid. Auto 64/2011 de la Audiencia Provincial de Cádiz, de 17 de mayo de 2011; Auto 98/2009 de la Audiencia Provincial de Madrid, de 8 de junio. 
tener es un posible "fumus boni iuris», que al llegar al momento de laudar puede haberse mutado por completo. Sistematizamos a continuación los factores que afectan a la generación de las responsabilidades que podrían derivarse para el árbitro en relación con esas medidas cautelares:

A) Decisión errónea en uno u otro sentido, que lleve aparejada la ocurrencia de perjuicios reales y efectivos para quien las solicitaba o se oponía a las mismas. Es decir, la responsabilidad se produce por acordarlas o por no acordarlas, dependiendo del caso concreto.

B) Para tomar la decisión sobre las medidas cautelares, salvo que las partes hayan pactado algo expresamente al respecto o en el caso de un arbitraje administrado el reglamento de la institución arbitral lo regule, el árbitro debe acudir literalmente a la legislación aplicable al Juez predeterminado en materia de medidas cautelares, interpretada a tenor de la jurisprudencia más reciente ${ }^{103}$. Y debe aplicarla y razonar su aplicación.

C) Fijación de una caución como contrapartida a la concesión de las medidas cautelares, en una cuantía proporcionada y lógica a tenor de la información que obre en poder del árbitro en ese momento procesal, especialmente si hay contradicción específica entre las partes al tratarse como un incidente del procedimiento arbitral.

D) Deposito de la caución hasta el levantamiento de las medidas cautelares o la terminación del arbitraje, procediendo en ese momento a la devolución de la misma o a su consignación

Nuestras sugerencias serían las siguientes:

- Tratar la solicitad de medidas cautelares como un incidente, que se inicia con un escrito de solicitud, que es contestado por quien se opone a las misma y subsidiariamente pide caución y que se sustancia en una vista. Se resuelve por el árbitro por medio de un laudo interlocutorio.

- El citado Laudo interlocutorio debe estar razonado y motivado y la decisión de conceder o no las medidas cautelares debe hacerse desde la óptica de la legislación que es de aplicación a los Jueces a este respecto. Con ello se evita en gran medida

${ }^{103}$ Este es un ejemplo más de la importancia y necesidad que defendemos de que el árbitro sea un jurista, incluso en los arbitrajes de equidad, con el fin de garantizar que el arbitraje llegue a buen puerto, sin «contaminaciones formales». 
que se pueda tildar de negligente o arbitraria la decisión del árbitro. Esa misma lógica aplica a la determinación de la caución, que debe ser siempre exigida para preservar la igualdad de las partes.

- La caución, en el caso de arbitrajes administrados, debe quedar en poder de la institución arbitral permanente. Si fuera un arbitraje ad hoc, el árbitro debiera abrir una cuenta corriente exclusiva para el depósito y en el caso de que la parte que solicitó las medidas cautelares sea la que haya visto reconocidas sus peticiones en el laudo, habrá de proceder a la devolución de la caución inmediatamente después de laudar. En el caso de que el solicitante de las medidas cautelares haya sido la parte vencida y el árbitro sospeche una posible situación de insolvencia de la citada parte, habrá de esperar a recibir una comunicación formal de la misma, exigiendo la restitución de la caución, a lo que deberá proceder en los días siguientes.

Cumpliéndose los puntos anteriores, a salvo de una intencionalidad dolosa del árbitro o de una negligencia grave de índole jurídica (p.e., conceder unas medidas cautelares cuyo contenido haya sido repudiado unánimemente por la jurisprudencia o que incluso sea contra legem), no se cumpliría el requisito de la intencionalidad en el grado suficiente para exigir responsabilidades al árbitro.

\subsection{Obligación de dictar, en tiempo oportuno, un laudo procedente, previendo que el mismo no contenga vicios que impidan que se convierta en firme y definitivo}

La trascendencia e importancia de «laudar bien» queda patente en el hecho de que el laudo arbitral tan solo admita una revisión de sus aspectos formales desde la jurisdicción estática y que despliegue los efectos de cosa juzgada. Sin embargo, la corriente jurisprudencial moderna, ya consolidada, avala la máxima del derecho a equivocarse al laudar de los árbitros, siempre que no medie dolo o negligencia grave, con independencia de que se trate de conceptuar la falta de motivación como una infracción del Orden Público. Es decir, el árbitro está obligado a tratar de hacer lo posible para laudar bien, para que sus decisiones sean lo más acertadas posible empleando una diligencia superior a la del buen padre de familia, pero no está libre de caer en el error, máximo porque no existe un «derecho al acierto» ni 
la «obligación de satisfacer la pretensión de ninguna de las partes del proceso» ${ }^{104}$.

Esta obligación es la misma, ya se trate de un arbitraje en el que tenga que decidir en derecho o en equidad, puesto que en el segundo, si bien puede actuar corrigiendo importantes asimetrías o desigualdades que debidamente justificadas le permiten apartarse de la norma jurídica general, que para un caso específico puede no ser aplicable, no significa que no se respeten las leyes o ser arbitrario sino que se deberá actuar en el marco de los principios reconocidos del Derecho ${ }^{105}$.

${ }^{104}$ Vid. Sentencia de Tribunal Constitucional, 288/1993; sentencia de Tribunal Superior de Justicia, Cataluña, Sala de lo Civil y Penal, 50/2014 de 14/07/2014; sentencia de Tribunal Supremo, Sala de lo Civil, de 23/03/1950; sentencia de Tribunal Supremo, Sala de lo Civil, 100/1994 de 15/02/1994; sentencia de Tribunal Supremo, Sala de lo Civil, 833/1997 de 04/10/1997; sentencia de Tribunal Supremo, Sala de lo Civil, 223/2001 de 13/03/2001; sentencia de Audiencia Provincial, Huesca, Sección 1. ${ }^{\text {, }}$, 52/2009 de 31/03/2001; sentencia de Tribunal Superior de Justicia, Comunidad de Madrid, Sala de lo Civil y Penal, 50/2012 de 02/07/2012; sentencia de Tribunal Supremo, Sala de lo Civil, de 13/10/1966; sentencia de Tribunal Supremo, Sala de lo Civil, de 16/02/1968; sentencia de Tribunal Constitucional, Sala Segunda, 32/2002 de 11/02/2002; sentencia de Tribunal Superior de Justicia, Comunidad de Madrid, Sala de lo Civil y Penal, 27/2014 de 20/05/2014; sentencia de Tribunal Supremo, Sala de lo Civil, de 24/01/1970.

${ }^{105}$ La necesidad de buscar la justicia por encima de la norma positiva, cuando su aplicación al caso concreto deviniera en una injusticia, nos acerca al concepto de ficción, puesto que GARCÍA GARRIDO, en De nuevo sobre las opuestas ficciones jurisprudenciales. Iuris vincula estudi in onore di Mario Talamanca IV 2003 página 53 y siguientes, «Decía que la ficción jurídica tiende a la corrección de una realidad concreta enderezada a hacer posible una aplicación de la regla a un caso al que, en principio, no es aplicable. Supuesto que el derecho dimana de un acto de voluntad que actúa el legislador o el magistrado, en virtud de su imperium, o de una actividad lógica, que caracteriza la interpretatio jurisprudencial, la ficción debe proceder de un acto imperativo y no de una actividad lógica. En las fuentes romanas, la ficción se presenta, en efecto, como un medio técnico jurídico al que recurre el pretor, para obviar un obstáculo o impedimento que se oponga a la concesión de una acción, o el legislador en la formulación de un precepto o principio de derecho. La jurisprudencia, que actúa en vía lógica e interpretativa, puede crear nuevo derecho mediante extensiones y equiparaciones analógicas, pero no puede imponer la ficción, que es un recurso alógico y de carácter imperativo. Los jurisconsultos romanos, cuya actividad repercutirá en todos los ámbitos de la vida jurídica, inspiraban al pretor y al legislador la introducción o aplicación de determinadas ficciones pero nunca las aplicaban directamente, porque la ficción aparece como atributo de un acto de autoridad al que no era posible llegar en vía interpretatio. Por ello, en las elaboraciones jurisprudenciales, la ficción se traduce en una equiparación de supuestos y circunstancias. Concluía que si se quiere dotar al concepto de ficción de unas características precisas, que la distinguen de la analogía y de otros medios de técnica jurídica, es necesario revestirla de estos tres caracteres especiales: A) Corrección de una realidad jurídica concreta; B) Operada por el juez; C) Impuesta por vía de imperio o potestas.

Proponía una definición de la ficción jurídica como el procedimiento técnico jurídico de remoción imperativa de un impedimento de hecho o de derecho que se oponga a la aplicación por el juez de un principio jurídico». 
4.5.1. Obligación de que el laudo respete la estructura formal exigida

La NLAB garantiza una gran flexibilidad tanto en la forma ${ }^{106}$ como en el contenido del laudo arbitral, que debe expresar, al menos, las circunstancias personales de los árbitros y de las partes, el lugar en que se dicta, la cuestión sometida a arbitraje, una sucinta relación de las pruebas practicadas, las alegaciones de las partes y la decisión arbitral motivada (en mayor o menor media, según se trata de una decisión en derecho o en equidad), en la que se incluirá lo relativo a las costas, así como la firma de los árbitros. Cumplidos estos requisitos mínimos, los defectos de la estructura del laudo no darán lugar a su anulación ${ }^{107}$.

En definitiva, en relación con esta obligación, las responsabilidades de los árbitros devendrían de una redacción del laudo que incumpliera los requisitos de estructura mínimos y que justificaran su anulación; así como de la falta de firma del laudo, de no mediar causa justificada para ello. Asimismo, en el caso de que el laudo tuviera que se inscrito en el Registro y su estructura formal impidiera tal Registro, se podría plantear una responsabilidad para el árbitro, siempre que la voluntad de inscripción de la laudo hubiera sido parte del mandato recibido de las partes.

Siendo los citados los hechos factuales, queda primero por apreciar su intencionalidad, que necesariamente debe ser en grado de dolo o negligencia grave. Ciertamente, en el caso de que el árbitro redactara un laudo sin cumplir los requisitos mínimos antes señalados, debemos afirmar que nos encontraríamos al menos en la esfera de la negligencia grave, dado que la sencillez de cumplimiento de los mismos es inexcusable si se emplea una mínima diligencia.

En cuanto a la determinación de los daños que se derivan de esa conducta, los mismos se producirán únicamente cuando el laudo fuera anulado por ese motivo o fuera imposible su registro y, por ende, no pudiera desplegar efectos constitutivos. Es, como hemos visto anteriormente, requisito imprescindible para la reclamación de responsabilidad, que se produzca la anulación del laudo por esa causa; y para que se produzca la anulación, en virtud del artículo 6 NLAB, es preciso que la parte que impugne el laudo hubiera antes usado el medio procesal a su alcance para corregir los errores formales del laudo,

${ }^{106}$ No es preciso que el laudo posea la estructura formal de una sentencia, aunque sea lo usual en la práctica y lo esperable en un buen arbitro.

${ }^{107}$ Vid. Sentencia de Tribunal Supremo, Sala de lo Civil, de 14/07/1971; sentencia de Tribunal Supremo, Sala de lo Civil, de 13/07/1982; sentencia de Tribunal Supremo, Sala de lo Civil, de 25/09/1987; sentencia de Tribunal Supremo, Sala de lo Civil, de 06/02/1989; sentencia de Tribunal Supremo, Sala de lo Civil, de 21/03/1990. 
que no es otro en este caso sino el recurso de aclaración del laudo. La cuantificación de los daños habrá de centrarse en el coste de arbitraje, ya que anulación del laudo obliga a esa parte a iniciar un nuevo proceso o a acudir a la jurisdicción estática, según lo dispuesto en el convenio arbitral.

En relación al laudo no firmado por todos los árbitros de un Colegio Arbitral, en este caso la responsabilidad sería exigible únicamente al árbitro disidente, si el mismo no emite un voto particular. Recordemos que el procedimiento arbitral es finalista y encuentra su satisfacción en un laudo firme y definitivo. Por lo tanto, el árbitro que no comparta la decisión de la mayoría, no está obligado a firmar el citado laudo, y aunque formalmente la NLAB le da la posibilidad pero no le obliga a emitir su voto particular, que podrá o no ser incluido en el laudo, tal y como sucede con las sentencias, siempre que fuera remitido en tiempo y forma al Presidente del Colegio Arbitral, tan solo con la emisión del mismo quedará prueba fehaciente de su diligencia como árbitro y de que la decisión de no firmar el laudo no se debe a desidia, negligencia o a cualquier conducta dolosa, sino a su firme convicción de que el contenido del mismo no es el adecuado en justicia.

Asimismo, ese voto discrepante será el que libere de posibles responsabilidades a ese árbitro, en el caso de que el laudo fuera anulado por causas imputables dolosamente o por negligencia grave a los otros árbitros firmantes del laudo.

Es importante volver a recordar que las responsabilidades pueden ser exigidas a los árbitros por cualquiera de las partes, con independencia de que nos encontremos con un Colegio Arbitral en el que cada parte hace un nombramiento y después consensuadamente se elige al Presidente. El hecho de haber sido nombrado por una parte en ningún caso le sitúa al árbitro en la esfera de tener que servir a los intereses de la misma, sino que muy al contrario, por imperativo legal, debe ser totalmente independiente e imparcial, por lo que sólo si a su juicio resulta adecuado expresar su voto discrepante en el laudo deberá proceder a ello. Y como reverso, si la parte que no le nombró, que normalmente soporta los costes arbitrales al 50 por ciento salvo que se haya optado por el criterio del vencimiento, considera que ha incumplido los deberes que le son propios como árbitro y se ha sustraído de la emisión y firma del laudo y no ha realizado el esfuerzo de plasmar el por qué de su decisión en un voto particular razonado, podrá instar una reclamación contra el mismo, fundamentada en una 
conducta que pudiera ser calificada como de grave negligencia, especialmente si se aprecia una voluntad entorpecedora del iter procesal arbitral, ampliamente denostada por la mejor jurisprudencia.

\subsubsection{Obligación de que el laudo respete el quórum exigido}

El hecho de que en una de las deliberaciones del Colegio Arbitral falte uno de los árbitros no presupone necesariamente indefensión de la parte que designó al árbitro ausente, puesto que éste en ningún caso actúa en representación de la parte que le nombró, pero sí que vicia el procedimiento formalmente, ya que en un entorno colegiado las deliberaciones y votaciones deben contar con la totalidad de los miembros del Colegio Arbitral, so pena de incurrir en una causa de anulación del laudo. Y ello es totalmente independiente de que, contando con el quórum necesario, las decisiones se adopten por unanimidad, por mayoría o por el voto de calidad del Presidente ${ }^{108}$.

No respetar el quórum en un entorno decisional colegiado supone una vulneración de los principios del procedimiento arbitral, pero lógicamente de ese hecho factual no se derivan directamente responsabilidades, ya que es preciso evaluar la intencionalidad de los árbitros (en este caso, necesariamente tenemos que hablar de dos de ellos, o del Arbitro Presidente); el daño causado y su cuantificación; y el nexo causal.

En cuanto a la intencionalidad, en este caso nuestra opinión es que tan solo tiene cabida el dolo o la negligencia grave, ya que resulta evidente, especialmente para aquellos a quienes se les exige una diligencia superior a la del buen padre de familia, que todas las deliberaciones y decisiones deben discutirse por la totalidad del Colegio Arbitral, reunidos física o virtualmente, con independencia de que las decisiones resultantes de las deliberaciones se tomen por unanimidad, mayoría o voto de calidad.

En cuanto al daño, es evidente que nada tiene que ver, con respecto a la afrenta a los principios de audiencia, igualdad y contradicción, incumplir el deber de quórum en una reunión en la que el Colegio Arbitral decida sobre temas logísticos del arbitraje, que en otra en la que se decida cuales son las pruebas que se van a aceptar o en otra

${ }^{108}$ Vid. Sentencia de Audiencia Provincial, Madrid, Sección 28, 200/2011 de 10/06/2011; sentencia de Tribunal Supremo, Sala de lo Civil, de 14/06/1971; sentencia de Tribunal Supremo, Sala de lo Civil, de 14/04/1976; sentencia de Tribunal Supremo, Sala de lo Civil, de 19/09/1987. 
que sea la reunión final de deliberación del laudo. Sin embargo, como venimos insistiendo, tal valoración no está en manos del árbitro o de la parte reclamante, sino exclusivamente del Tribunal Superior de Justicia que conozca de la acción de impugnación instada por la parte reclamante, a quien para ello se le exige haber previamente expuesto, de haberle sido posible, este incumplimiento dentro del ámbito procesal arbitral. Por lo tanto, el daño será siempre la anulación del laudo por esta causa, y la cuantificación del mismo vendrá dada por los costes del arbitraje, ya que la parte habrá de iniciar un nuevo procedimiento, arbitral o judicial, según preceptúe el convenio arbitral.

En cuanto al nexo causal, el mismo es evidente, ya que la anulación del laudo se produce por la actuación de los árbitros -o del árbitro presidente- excluyendo al otro u otros árbitros. El caso del árbitro presidente sería extremo, porque consistiría en ignorar a los otros dos árbitros, negándoles la posibilidad de deliberar y de que incluso pudieren alcanzar ellos una decisión por mayoría diferente de la del Presidente, y así resolver en solitario haciendo uso de su voto de calidad, que le daría una falsa apariencia de buen derecho a su decisión. Aunque disparatado como ejemplo, lógicamente presupondría dolo por parte del Arbitro Presidente, siendo el daño de esta acción los costes del arbitraje, siempre que el laudo fuera anulado por esta causa, instada por la parte reclamante. El nexo causal entre la actuación del árbitro y el daño es evidente.

\subsubsection{Obligación de que el laudo no sea contrario al orden público ${ }^{109}$}

Una delimitación más concreta de «orden público» para aclarar la zona de incertidumbre que comporta este concepto jurídico indeter-

${ }^{109}$ Vid. Resolución de Dirección General Registros y Notariado, de 06/04/1917; sentencia de Tribunal Constitucional, 19/1985 de 13/02/1985; Auto de Tribunal Supremo, Sala de lo Civil, de 20/06/2000; sentencia de Tribunal Supremo, Sala de lo Civil, de 07/10/2003; sentencia de Audiencia Provincial, Baleares, de 18/07/1995; sentencia de Audiencia Provincial, Barcelona, Sección 14. ${ }^{\text {, }}$, de 03/09/2003; sentencia de Audiencia Provincial, Barcelona, de 18/03/1991; sentencia de Audiencia Provincial, Barcelona, de 18/07/1995; sentencia de Audiencia Provincial, Burgos, 542/2003 de 18/12/2003; sentencia de Audiencia Provincial, La Coruña, de 25/04/1994; sentencia de Audiencia Provincial, Madrid, sección 10, de 10/12/1991; sentencia de Audiencia Provincial, Madrid, de 14/09/1990; sentencia de Audiencia Provincial, Madrid, de 24/04/1991; sentencia de Audiencia Provincial, Madrid, de 26/11/1991; sentencia de Audiencia Provincial, Madrid, de 10/04/1992; sentencia de Audiencia Provincial, Madrid, de 12/06/1995; sentencia de Audiencia Provincial, Madrid, de 17/10/1995; sentencia de Audiencia Provincial, Madrid, de 31/10/1995; sentencia de Audiencia Provincial, Málaga, de 01/09/1993; sentencia de Audiencia Provincial, Málaga, de 25/06/1996; sentencia de Audiencia Provincial, País Vasco, de 20/02/1991; sentencia 
minado permite la distinción entre orden público material y orden público procesal. Desde el punto de vista del orden público sustantivo no se pueden someter a arbitraje cuestiones que están fuera de la disposición de las partes, o que los árbitros, al decidir, hubieran vulnerado un derecho fundamental o libertad pública, resultando para el Tribunal Constitucional que sólo atenta al orden público la vulneración de los derechos fundamentales y libertades públicas. Atinente al orden público procesal, se trataría de determinar si se ha producido una infracción del derecho a la tutela judicial efectiva del artículo 24 de la Constitución, sin que se haya producido una indefensión real y material constitucionalmente relevante.

Si por orden público material se entiende el conjunto de principios públicos, privados, políticos, morales y económicos que son absolutamente obligatorios para la conservación de la sociedad en un pueblo y en una época determinada y desde el punto de vista procesal, el orden público se configura como el conjunto de formalidades y principios necesarios de nuestro ordenamiento jurídico procesal, sólo el arbitraje que contradiga alguno o algunos de tales principios podrá ser tachado de nulo por vulneración del orden público.

Adicionalmente, por imperativo del Derecho de la Unión Europea, el ámbito propio de la acción de anulación debe comprender lo que se ha dado en llamar orden público económico, en el que se incluyen

de Audiencia Provincial, País Vasco, de 22/06/1994; sentencia de Audiencia Provincial, Pontevedra, de 19/11/1996; sentencia de Audiencia Provincial, Santa Cruz, sección 1, 507/2003 de 17/11/2003; sentencia de Audiencia Provincial, Santa Cruz, Sección 4. ${ }^{\text {a }}$, de 08/09/2003; sentencia de Audiencia Provincial, Zaragoza, de 27/05/1994; auto de Tribunal Constitucional, Sala Primera, Sección 1. a, 701/1988 de 06/06/1988; sentencia de Tribunal Constitucional, Sala Segunda, 176/1996 de 11/11/1996; Auto de Tribunal Constitucional, Sala Segunda, Sección 4. ', 116/1992 de 04/05/1992; sentencia de Tribunal Constitucional,, de 31/03/1981; sentencia de Tribunal Constitucional, 22 /1982 de 12/05/1982; sentencia de Tribunal Constitucional, 47/1982 de 12/07/1982; sentencia de Tribunal Constitucional, , 26/1983 de 13/04/1983; sentencia de Tribunal Constitucional, 47/1983 de 31/05/1983; sentencia de Tribunal Constitucional, 48/1984 de 04/04/1984; sentencia de Tribunal Constitucional, 67/1984 de 07/06/1984; sentencia de Tribunal Constitucional, 51/1985 de 10/04/1985; sentencia de Tribunal Constitucional, 7/1986 de 21/01/1986; sentencia de Tribunal Constitucional, 48/1986 de 23/04/1986; sentencia de Tribunal Constitucional, 77/1986 de 12/06/1986; sentencia de Tribunal Constitucional, 55/1987 de 13/05/1987; sentencia de Tribunal Constitucional, 96/1987 de 10/06/1987; sentencia de Tribunal Constitucional, 145/1988 de 12/07/1988; sentencia de Tribunal Constitucional, 169/1988 de 29/09/1988; sentencia de Tribunal Constitucional, 22/1988 de 25/11/1988; sentencia de Tribunal Constitucional, 54/1989 de 23/02/1989; sentencia de Tribunal Supremo, Sala de lo Civil, de 05/05/1988; sentencia de Tribunal Supremo, Sala de lo Civil, de 02/03/1989; sentencia de Tribunal Supremo, Sala de lo Civil, de 29/03/1989; sentencia de Tribunal Superior de Justicia, Comunidad de Madrid, Sala de lo Civil y Penal, 13/2015 de 28/01/2015; sentencia de Tribunal Supremo, Sala de lo Civil, 464/2014 de 08/09/2014. 
mente aquéllos sometidos al principio de congruencia, sin que puedan traspasar los límites del compromiso resolviendo cuestión no sometida a su decisión; pero eso no implica que estén obligados a interpretarlo tan restrictivamente que se coarte su misión decisoria de conflictos de forma extrajudicial, sino que la naturaleza y finalidad del arbitraje permita una mayor elasticidad en la interpretación de las estipulaciones que describen las cuestiones a decidir, las que deben apreciarse no aisladamente, sino atendiendo a aquella finalidad y a sus antecedentes, pudiendo reputarse comprendidas en el compromiso aquellas facetas de la cuestión a resolver íntimamente vinculadas a la misma y sin cuya aportación quedaría la controversia insuficientemente fallada; es decir, el árbitro puede resolver cuestiones que sean consecuencia lógica y obligada de las que se han planteado; conclusiones derivadas de la naturaleza jurídica del compromiso arbitral que se hallan corroboradas por la interpretación que ha de darse al acuerdo contractual delimitador de aquellas cuestiones controvertidas y pendientes objeto de arbitraje, en cuya operación ha de tenerse en cuenta el espíritu y finalidad que haya presidido el negocio infiriéndolos de las circunstancias concurrentes y de la total conducta de los interesados, teniendo importancia muy relevante, la conexión que el acto o negocio guarde con otros que le hayan servido de antecedente.

Tribunal Supremo, Sala de lo Civil, de 11/04/1932; sentencia de Tribunal Supremo, Sala de lo Civil, de 13/05/1933; sentencia de Tribunal Supremo, Sala de lo Civil, de 11/05/1934; sentencia de Tribunal Supremo, Sala de lo Civil, de 11/05/1954; sentencia de Tribunal Supremo, Sala de lo Civil, de 26/10/1961; sentencia de Tribunal Supremo, Sala de lo Civil, de 18/10/1962; sentencia de Tribunal Supremo, Sala de lo Civil, de 23/05/1967; sentencia de Tribunal Supremo, Sala de lo Civil, de 15/02/1969; sentencia de Tribunal Supremo, Sala de lo Civil, de 19/12/1972; sentencia de Tribunal Supremo, Sala de lo Civil, de 02/02/1978; sentencia de Tribunal Supremo, Sala de lo Civil, de 16/02/1982; sentencia de Tribunal Supremo, Sala de lo Civil, de 25/10/1982; sentencia de Tribunal Supremo, Sala de lo Civil, de 04/02/1983; sentencia de Tribunal Supremo, Sala de lo Civil, de 20/10/1997; sentencia de Tribunal Supremo, Sala de lo Civil, de 27/12/1956; sentencia de Tribunal Supremo, Sala de lo Civil, de 06/04/1942; sentencia de Tribunal Supremo, Sala de lo Civil, de 17/11/1970; sentencia de Tribunal Supremo, Sala de lo Civil, de 23/03/1940; sentencia de Tribunal Supremo, Sala de lo Civil, de 22/10/1973; sentencia de Tribunal Superior de Justicia, Canarias, Sala de lo Civil y Penal, 1/2014 de 29/04/2014; sentencia de Tribunal Superior de Justicia, Castilla y León, Sala de lo Civil y Penal, 2/2013 de 07/03/2013; sentencia de Tribunal Superior de Justicia, Cataluña, Sala de lo Civil y Penal, 56/2013 de 07/10/2013; sentencia de Tribunal Superior de Justicia, Comunidad de Madrid, Sala de lo Civil y Penal, 33/2014 de 03/06/2014; sentencia de Tribunal Superior de Justicia, Comunidad de Madrid, Sala de lo Civil y Penal, 33/2015 de 21/07/2015; sentencia de Tribunal Superior de Justicia, Comunidad Valenciana, Sala de lo Civil y Penal, 5/2015 de 13/02/2015; sentencia de Tribunal Superior de Justicia, País Vasco, Sala de lo Civil y Penal, 6/2013 de 13/05/2013. 
Toda interpretación, y por consiguiente, tanto la de las normas como la de los negocios jurídicos, al ir dirigida a indagar el significado efectivo y el alcance de una manifestación de voluntad, exige, fundamentalmente, captar el elemento espiritual, la voluntad o intención de los sujetos declarantes contenida en la Ley o en el acto jurídico, sin limitarse al sentido aparente e inmediato que resulte de las palabras; y esta doctrina, acogida sustancialmente a propósito de la interpretación de los contratos, no puede menos de ser aplicable cuando de la comprobación del contenido del convenio arbitral se trata, siendo consecuencia de ello que el resultado de la interpretación, en las convenciones de esta clase, como en cualquier otro negocio jurídico, será, según los casos, restrictivo, extensivo o meramente declarativo, sin que pueda decirse, en términos generales, que el arbitraje merezca siempre una interpretación restrictiva, ya que si bien es verdad que pesa sobre los árbitros el deber inexcusable de no quebrantar la voluntad de las partes consignada en el convenio arbitral la norma a que se someten las partes y traza el círculo en que debe desenvolverse la actividad de los árbitros, no es menos cierto que el convenio no comprende únicamente los objetos en él expresados determinadamente, sino también los que, por una inducción necesaria de sus palabras, deban reputarse comprendidos en el mismo y que el sentido de las cláusulas del compromiso hay que fijarlo, no por la expresión aislada de una, sino por el conjunto de todas ellas y por los antecedentes que puedan explicar la finalidad que se propusieron los otorgantes, de modo tal que, en definitiva, si bien los árbitros no pueden traspasar los límites objetivos del compromiso, tampoco están obligados a interpretarlo con demasiada restricción apartándose de la misión amistosa y cordial que se les encomienda.

El requisito de la congruencia es la exigencia derivada de la conformidad que ha de existir entre la sentencia y las pretensiones que constituyen el objeto del proceso, y existe congruencia ahí donde la relación entre estos dos últimos términos, fallo y pretensiones deducidas $^{112}$, no está sustancialmente alterada, sin que, en definitiva, otorgar menos de lo pedido signifique modificación de la causa petendi. Los términos de comparación para determinar la congruencia- incon-

${ }^{112}$ Aun teniendo en cuenta la flexibilidad que preside el proceso arbitral, se impone en todo caso la necesidad de que se determine objetivamente la controversia conforme a las alegaciones de las partes, individualizándose la pretensión por una serie de elementos subjetivos y objetivos, que en términos comparativos permitirán determinar si la decisión adoptada por el árbitro se ajusta o no, de manera congruente, con la demanda y demás pretensiones deducidas en el procedimiento deduciendo todos los puntos litigiosos que hayan sido objeto de debate. 
gruencia de una resolución son la propia resolución, que se concibe además en su totalidad y no solo respecto a la parte dispositiva, y las pretensiones interpuestas por las partes, que igualmente van más allá de la súplica para integrarse con la fundamentación e incluso con alegaciones complementarias, actos dispositivos y, tratándose de un laudo, con el convenio arbitral.

Surgirá la incongruencia cuando resuelvan los árbitros, más allá de lo pedido (ultra petita), no decidiendo sobre alguno de los puntos objeto de la controversia (minus petita) o bien haciéndolo sobre cuestiones no planteadas (extra petita). La incongruencia que se contempla en la NLAB es la denominada incongruencia extra petita, vicio del laudo que resuelve sobre cuestiones no sometidas a los árbitros, vinculada con el principio dispositivo como fundamento del deber de los árbitros de no pronunciarse sobre puntos que no les fueron sometidos, o de pronunciarse de forma distinta a lo pedido. El vicio de incongruencia puede darse bien por no responderse a cuestiones planteadas (incongruencia omisiva) ${ }^{113}$ siempre que el silencio no pueda interpretarse como desestimación tácita y también si se concede más de lo pedido (incongruencia ultra petita). La incongruencia mixta también es denunciable al amparo de lo previsto para la incongruencia como base para la anulación del laudo, en tanto en cuanto este tipo de incongruencia supone una combinación de los dos tipos de incongruencia antes descritos. Es decir, si los árbitros deciden puntos distintos a los que les han sido sometidos, están, de un lado, dejando de resolver puntos sometidos (incongruencia negativa) y resolviendo puntos no sometidos (incongruencia positiva).

No cabe duda de que la incongruencia como motivo de nulidad del laudo ${ }^{114}$ puede ser invocada, pues rigen en el procedimiento arbitral los mismos principios que en los procedimientos comunes de la Ley de Enjuiciamiento Civil en orden a la salvaguarda de los principios de contradicción procesal y defensa. Es reiterada la doctrina

${ }^{113}$ La incongruencia omisiva o ex silentio es un quebrantamiento de forma que sólo alcanza relevancia constitucional y determina la vulneración del art. 24.1 CE cuando, al dejar imprejuzgada una cuestión litigiosa. La letra c) del artículo 41 de la Ley de Arbitraje acoge la incongruencia extra petita, pero no la incongruencia omisiva o ex silentio. Esta última, referida al deber de exhaustividad al que también están obligados los árbitros, solo puede fundarse en la letra f) de dicho precepto articulándose a través de la contravención del orden público y por infracción del artículo 24.1 de la Constitución.

${ }^{114}$ El ejercicio de la acción de anulación sobre la base de un exceso o un defecto de jurisdicción de los árbitros viene condicionado por la existencia de una reclamación previa en sede arbitral. 
jurisprudencial en torno a la congruencia, de la que se extrae, en esencia, que el deber de congruencia consiste en la necesaria exigencia de conformidad entre el contenido del laudo arbitral y las pretensiones deducidas en los suplicos de los escritos fundamentales rectores del proceso, siempre respetando los hechos alegados y la causa de pedir, resolviendo todos los puntos litigiosos. La congruencia existe allí donde la relación entre estos dos términos, fallo y pretensiones procesales, no está sustancialmente alterada, aunque no se requiere desde luego una correlación literal y rígida, sino racional, sustancial y flexible.

La congruencia exigible al laudo se predica de las concretas pretensiones contenidas en los escritos de las partes, y no de las meras alegaciones o argumentaciones aportadas por las mismas en defensa o apoyo de aquellas. La congruencia de las sentencias no exige una correspondencia absolutamente rígida entre lo pedido y lo acordado sino que también se cumple cuando el fallo, pese a no concordar literalmente con lo pedido, se adecue racionalmente a las pretensiones de las partes y a los hechos que las fundamenten, hasta el punto de ser admisibles pronunciamientos complementarios del juzgador no pedidos por las partes pero sí encaminados a facilitar la ejecución del fallo o a evitar nuevos pleitos.

La Jurisprudencia afirma que el principio iura novit curia permite al Juez fundar el fallo en los preceptos legales o normas jurídicas que sean de pertinente aplicación al caso, aunque los litigantes no las hubieren invocado, y que el juzgador sólo está vinculado por la esencia y sustancia de lo pedido y discutido en el pleito, no por la literalidad de las concretas pretensiones ejercitadas, tal y como hayan sido formuladas por los litigantes, de forma que no existirá incongruencia extra petitum cuando el Juez o Tribunal decida o se pronuncie sobre una de ellas que, aun cuando no fuera formal y expresamente ejercitada, estuviera implícita o fuera consecuencia inescindible o necesaria de los pedimentos articulados o de la cuestión principal debatida en el proceso. Tal doctrina ha de aplicarse, con mayor razón, a los laudos pues se mantiene por la doctrina que no pueden aplicarse sobre el procedimiento arbitral los mismos principios que rigen para la jurisdicción ordinaria, en especial tras la entrada en vigor de la NAL, considerando que el principio de flexibilidad que inspira el procedimiento arbitral debe también presidir el examen de la congruencia del laudo.

La congruencia, como motivo de nulidad de laudo arbitral, regulado en el artículo 41.1.c) NLAB, ha de ser examinada teniendo pre- 
sente el convenio arbitral y las alegaciones realizadas por las partes en el proceso arbitral, debiéndose resolver conforme a la obligada flexibilidad que preside el señalado proceso arbitral; rechazándose si existe el debido ajuste entre lo solicitado y lo decidido. Ello sin perjuicio de que el desajuste -de producirse- pueda también suponer una infracción de los principios de defensa, audiencia y contradicción desde el punto de vista del orden público procesal. Dentro de la debida y adecuada elasticidad que debe presidir el examen de la congruencia del laudo, es de aplicación la llamada «teoría de sustanciación», que propugna que no se produce alteración de la causa de pedir cuando la modificación no incide en la sustancia fáctica de la pretensión -el conjunto de acontecimientos de la vida en que la pretensión se apoya-, sino solo cuando el fundamento determinante de la decisión judicial toma en cuenta hechos distintos de los que conforman el objeto del proceso, entre los cuales no se encuentran todos los de la narración histórica, ni siquiera siempre todos los constitutivos, sino sólo aquellos con relevancia jurídica para individualizar e identificar la pretensión procesal. Y, en cualquier caso, cuando se otorga algo incluso no pedido, pero que es impuesto por la Ley, no se produce incongruencia alguna.

Entrando a analizar las consecuencias de la incongruencia del laudo debemos centrarnos en primer lugar en si se trata de una incongruencia omisiva, extra petita, ultra petita o mixta.

Como antes hemos señalado, la incongruencia omisiva difícilmente puede encontrar cabida en el marco normativo de la NLAB, especialmente porque como ha señalado la jurisprudencia, aún en el caso de que tuviera relevancia constitucional la cosa imprejuzgada, le cabría la posibilidad al árbitro de corregir esa incongruencia en el recurso de aclaración, que obligatoriamente debe presentar la parte qué posteriormente desee instar la acción de impugnación, pidiendo las explicaciones precisas para tratar de lograr que la incongruencia omisiva sea corregida por el árbitro. La no presentación del citado recurso de aclaración supone la imposibilidad de instar la citada incongruencia omisiva, al amparo de la vulneración del orden público, como causa de anulación del Laudo. Por lo tanto, como vemos, hay pocas posibilidades de que se puedan exigir responsabilidades al árbitro por incongruencia omisiva. No obstante, nuestra recomendación para minimizar aún más el riesgo es que el árbitro utilicé fórmulas de estilo en la redacción de su laudo y resoluciones interlocutorias qué permitan inferir de las mismas que lo no tratado específicamente en ellos se da por rechazado o no estimado. 
La incongruencia extra petita es la que encuentra una regulación más específica en la NAL, contemplándola como una causa específica de anulación del laudo. Así, es claro que es un hecho factual generador de responsabilidad para el árbitro. Sin embargo, es preciso determinar el grado de intencionalidad, la existencia y cuantificación del daño, y el nexo causal entre el hecho factual y el citado daño.

Indiscutiblemente, en la comisión de la incongruencia extra petita puede concurrir dolo o negligencia grave, dependiendo de las circunstancias. Nos encontraremos con dolo cuando el árbitro, de forma maliciosamente intencional, haya decidido fallar sobre materias excluidas de su decisión con el fin de beneficiar a una de las partes o de perjudicar a la otra o ambas cosas. Podremos apreciar negligencia grave cuando podamos afirmar que cualquier persona capaz de ser árbitro, empleando una diligencia superior a la del buen padre de familia, hubiera sido capaz de entender y comprender, sin margen de error, cuál era el contenido de la controversia acordado por las partes y sometido a la decisión del árbitro. Por ello, siendo fácil de determinar el ámbito de la controversia, el hecho de que el árbitro se extralimite en su fallo implica una falta de diligencia y una impericia que pueden ser tildadas de negligencia grave.

Con respecto a la incongruencia ultra petita podemos hacer las mismas precisiones que con la incongruencia extra petita, con la única matización de que no incurrirá en responsabilidad el árbitro si en su decisión no va más allá de lo solicitado sino porque ello sea una consecuencia necesaria de la decisión resolutoria, necesaria para completarla o ejecutarla; o porque así le venga obligado por una norma imperativa. Por su parte, la incongruencia mixta, al albergar tanto incongruencia extra petita como omisiva, habrá de ser analizada separadamente en cada uno de sus componentes, puesto que sus consecuencias también serán diferenciadas al ser apreciado o no cada uno de ellos.

Entrando ahora a valorar cuál es el daño qué se produce para la parte que reclama responsabilidades al árbitro en las diferentes opciones de incongruencia, debemos precisar que en el caso de la incongruencia extra petita y ultra petita, siempre que se pueda separar en el laudo la parte de la decisión que se ha extralimitado del ámbito de la controversia, de la parte ajustada a lo que las partes querían que fuera conocido y resuelto por el árbitro, no habría daño puesto que el laudo no sería anulado por esta causa, procediéndose únicamente a la anulación de la parte incongruente del laudo, en aplicación el principio de conservación del arbitraje. 
$\mathrm{Si}$, por contra, la parte dispositiva del laudo que se considera incongruente se encontrara indisolublemente unida al resto de materias que resuelve el mismo, ello devendrá en la anulación total del laudo y se producirán como daño las costas arbitrales, puesto que las partes se verán abocadas a un nuevo procedimiento arbitral o a acudir a la jurisdicción estática, dependiendo de lo que establezca el convenio arbitral que se otorgaron.

Por último, a la hora de evaluar el nexo causal entre la conducta reprobable del árbitro en cualquiera de las diferentes vertientes de la incongruencia y el daño derivado de la misma, decir que él elemento que permite apreciar su existencia es la anulación del laudo arbitral sobre la base del hecho factual de la incongruencia. Existiendo tal circunstancia, se completan los requisitos necesarios para exigir la responsabilidad civil del árbitro por un laudo incongruente.

\subsubsection{Obligación de que el laudo no sea extemporáneo}

El laudo dictado fuera de plazo ${ }^{115}$ es válido, no adolece de vicio alguno, pues se equipara la irregularidad a la que se produce con la sentencia dictada fuera de plazo, que no resulta afectada en su validez y eficacia. La única consecuencia de la infracción del plazo se reduce a la eventual responsabilidad del árbitro, siempre que adicionalmente concurran los requisitos de intencionalidad, daño efectivo cuantificable y nexo causal.

No obstante, las partes puede decidir fijar como requisito el establecimiento de un plazo preclusivo para dictar la resolución, transcurrido el cual el laudo que se dictara sería extemporáneo y por ende inválido, anulable por el motivo de incumplimiento de principios del procedimiento, ya que el artículo 41.1 LAB no recoge un motivo específico para la extemporaneidad, ya que la misma será la excepción.

En este caso el hecho factual es la emisión del lado después de la fecha máxima fijada para ello, una circunstancia que salvo excepciones muy contadas es sencillo de determinar, por lo que el reconocimiento de si ha existido o no esta conducta reprobable del árbitro es fácil. No obstante, de la ocurrencia de la misma no sé derivan de for-

${ }^{115}$ Vid. Sentencia de Audiencia Provincial, Barcelona, de 31/10/1997; sentencia de Audiencia Provincial, Cantabria, de 08/04/2005; sentencia de Audiencia Provincial, Madrid, de 23/12/2008; sentencia de Audiencia Provincial, Segovia, de 29/12/2008; sentencia de Tribunal Superior de Justicia, Andalucía, Sala de lo Civil y Penal, 7/2013 de 01/03/2013; sentencia de Audiencia Provincial, Madrid, de 29/07/2005. 
ma directa y automática responsabilidades exigibles al árbitro, sino que como siempre han de concurrir los factores de intencionalidad, existencia y cuantificación del daño, y existencia del nexo causal entre el hecho factual y el daño.

Comencemos nuestro análisis por la intencionalidad, afirmando que la misma en los laudos extemporáneos puede ser reconocida fácilmente a tenor del comportamiento que las partes hayan tenido en el procedimiento arbitral. De este modo, si nos encontramos con que una de ellas, que normalmente será la que reclame al árbitro, durante todo el procedimiento arbitral ha desarrollado una política de obstrucción y de enlentecimiento del proceso, entonces una gran parte de la culpa de que el árbitro haya laudado fuera de plazo recaerá en la citada parte, lo que hace imposible considerar imputable al árbitro por negligencia grave, al haber una compartición de la culpa.

Resulta también muy clarificador, a la hora de determinar si el retraso a la hora de emitir el laudo puede ser calificado como negligencia grave, analizar la complejidad de la litis, con especial atención al volumen probatorio solicitado por las partes, tanto en lo que se refiere a pruebas de confesión, testificales y periciales, que implican mucho tiempo tanto en su logística de preparación, como en su desarrollo y posterior análisis de las mismas. Recordemos que aunque el árbitro tiene la potestad de decidir qué pruebas acepta o no, siempre está bordeando la línea roja de la indefensión al rechazar una prueba propuesta por una parte si finalmente de la misma pudieran derivarse datos e información nueva con efecto relevante en el sentido de la decisión arbitral.

Por lo tanto, nuestra sugerencia en aquellos casos en los que la $l i$ tis sea compleja y haya mucho volumen probatorio, es que el árbitro haga uso de la prerrogativa que le concede la NAL de ampliar dos meses el plazo para laudar, y si mediara pacto de las partes en contra de esa posibilidad, que solicite a las partes una ampliación del plazo para laudar, con el fin de poder garantizar que el procedimiento arbitral y el resultado del mismo, es decir, el laudo, tengan las mayores garantías de calidad. Si las partes rechazaran la citada posibilidad, el árbitro tendría después más argumentos a la hora de defender que no incurrió en negligencia grave al no ser capaz de emitir el lado en el plazo fijado para ello por las partes.

También tiene una influencia directa en la velocidad del procedimiento arbitral el hecho de que en lugar de haber un árbitro único se trate de un Colegio Arbitral, puesto que ello implica que todas las 
decisiones, excepto las instrumentales de simplemente ordenación procesal, sean colegiadas y haya mediado una deliberación previa. Por lo tanto, se introducen necesariamente dentro del procedimiento arbitral una serie de deliberaciones que obligan a la coordinación de las agendas de los árbitros, por lo que aparte del tiempo adicional que su desarrollo supone, prolongan el procedimiento en los días necesarios para conseguir coordinar una fecha adecuada para todos los árbitros en que celebrarse, puesto que recordemos que una falta de quórum podría llevar a la anulación del laudo por incumplimiento de principios rectores del arbitraje.

Los supuestos en los que concurre dolo o negligencia grave en el comportamiento del árbitro suelen ser fácilmente reconocibles, ya que el árbitro en lugar de propiciar el impulso del arbitraje ralentiza el mismo y va incumpliendo los plazos fijados para las diferentes etapas procedimentales, dificultando el desarrollo del iter arbitral. Se suele asociar el dolo en este tipo de comportamientos a escenarios en los que una de las partes se ha opuesto al arbitraje y ha tratado sin éxito de que se frustrara, y decide impropiamente jugar la baza de elegir a un árbitro dentro de la terna que compone el colegio arbitral que se preste a esta reprobable conducta, con la esperanza de conseguir argumentos que puedan llevar a provocar la anulación del laudo. Este tipo de comportamientos hacen muy complicado el desarrollo del arbitraje para el Presidente del Colegio Arbitral, quién debe sufrir deliberaciones interminables que normalmente acaban siempre con decisiones tomadas por mayoría o incluso por el voto de calidad del Presidente. Sin embargo, lógicamente, en el caso de que finalmente el laudo extemporáneo fuera anulado por haber pactado las partes un plazo preclusivo para el mismo, las responsabilidades que se podrían depurar del Colegio Arbitral no serían comunes para todos los miembros del mismo, sino que debieran centrarse en el árbitro que con su comportamiento hubiera propiciado el retraso. Y es que debemos recordar que esas responsabilidades le pueden ser exigidas incluso por la parte que no propuso su nombramiento, ya que no existe ninguna correlación entre el árbitro y la parte que le propusiera, siendo la expresión «árbitro de parte» un terrible error conceptual, puesto que ningún árbitro sirve a ninguna de las partes sino exclusivamente a la búsqueda de la justicia, como señala GONZÁLEZ SORIA ${ }^{116}$.

En cuanto a la realidad del daño y la cuantificación del mismo derivado de un laudo extemporáneo, debemos diferenciar claramente

${ }^{116}$ Cfr. GONZÁLEZ SORIA, Julio. Reflexiones básicas sobre el arbitraje. SAR. Madrid. 2015. 
dos situaciones totalmente distintas: La primera, cuando el laudo haya sido anulado por haberse dado las partes un plazo preclusivo para su emisión, lo que provoca que desde el día siguiente a la caducidad del mismo el árbitro pierda el poder del que ha sido investido por las partes para laudar; y la segunda, que las partes se hayan ajustado a lo previsto por defecto en la NLAB, que contempla específicamente, sobre la base del principio de conservación del arbitraje, que el laudo extemporáneo será siempre válido, con independencia de que el retraso en laudar implique la depuración de responsabilidades para el árbitro.

Por lo tanto, en el primer caso el daño es evidente, puesto que consiste en la anulación del laudo, lo que obliga a las partes a iniciar un nuevo procedimiento arbitral o acudir a la jurisdicción estática, dependiendo de lo que hubieran previsto en el convenio arbitral regulador del arbitraje fallido. En el segundo caso, dado que el laudo no pierde sus efectos, el daño debe evaluarse en atención al impacto económico negativo que haya podido tener para las partes la demora en contar con el citado laudo como base para la ejecución de lo en él resuelto. Lógicamente, esto entraña una mayor dificultad probatoria para el reclamante, pues se habrán de dar casos muy excepcionales en los que una demora razonable en el plazo para laudar, que nosotros entendemos en los dos meses que la propia NAL sugiere que se permitan de ampliación por parte de los árbitros de forma directa, haya producido de forma cierta y cuantificada un daño emergente o un lucro cesante para la parte reclamante.

Pasemos ahora a analizar el último elemento de la responsabilidad del árbitro, que es el nexo causal con el daño producido. En el caso del laudo anulado por extemporáneo, el nexo causal es fácil de determinar si se trata de un árbitro único, y su actuación a lo largo del procedimiento arbitral ha hecho imposible que se cumpliera el plazo previsto por las partes para la emisión del laudo. En el caso de un Colegio Arbitral es más complicado, porque se deben singularizar los comportamientos de cada uno de los miembros del Colegio Arbitral y atribuirles en la medida que sea adecuado su parte de responsabilidad en el retraso. Recordemos que la responsabilidad exige una imputabilidad personal en el ámbito de la NAL, sin que quepa equiparar al Colegio Arbitral con la institución arbitral, lo que significa que la reclamación debe presentarse contra cada uno de los miembros del Colegio Arbitral de forma individualizada, sin que exista la posibilidad jurídica de reclamar al Colegio Arbitral -carente de personalidad jurídica- y que después los diferentes miembros traten de repercutirse entre sí la posible indemnización a la que tuvieran que hacer fren- 
te. Lo que sí que cabría es plantear un litisconsorcio pasivo de los árbitros al igual que conceptualmente también tendría sentido un litisconsorcio activo de las partes, si estas coinciden en que la actuación del árbitro o de los árbitros les ha producido un perjuicio indemnizable en virtud de la NLAB.

Cuando el daño producido venga motivado por la demora en contar con el laudo, el nexo causal debe poner en relación el contar con el laudo en una fecha posterior a la máxima fijada para ello, como consecuencia de la conducta del árbitro, y el citado daño.

La última reflexión que debemos hacer en relación a este tema pone en relación los artículos 6 y el 19 de la NAL, en el sentido de si hemos de entender como requisito previo para que se puedan exigir responsabilidades al árbitro en un laudo extemporáneo que previamente se haya instado su remoción al entender la parte reclamante que no está ejerciendo sus funciones en un plazo razonable, lo que previsiblemente le llevaría a laudar fuera de plazo. Es decir, la duda estriba en si debemos considerar el remedio procesal adecuado para una conducta arbitral incumplidora de sus funciones la solicitud de remoción, ya sea ante el Juez de Primera Instancia en arbitrajes con árbitro único; o ante el Colegio Arbitral, en arbitrajes con multiplicidad siempre impar de árbitros. Y nuestra respuesta debe ser claramente afirmativa, en coherencia con el espíritu del Legislador al incluir el artículo 6 NAL y buscar la preservación del arbitraje y blindarlo de usos espurios de los trucos procesales. Una de las consecuencias derivadas de una decisión del Colegio Arbitral en la que rechace la remoción y después se constate que existía la actitud incumplidora de sus responsabilidades del árbitro, que persistió coadyuvando a la extemporaneidad del laudo, es que entonces la tacha de responsabilidad por ese hecho factual les alcanzará igualmente a los otros árbitros en grado subsidiario.

\section{OBLIGACIONES DEL ÁRBITRO POSTERIORES A LA EMISIÓN DEL LAUDO}

\subsection{Protocolización del laudo}

No siendo obligatoria salvo acuerdo expresa de las partes sensu contrario, desde el punto de vista de la responsabilidad del árbitro, en cuanto a fehaciencia de fecha y contenido del laudo, la protocolización es una garantía para el árbitro diligente, puesto que le permitirá dar fe de los anteriores extremos en el ámbito de una potencial recla- 
mación. Por lo tanto, debiera recomendar a las partes que acordaran la protocolización, a su cargo; y, en caso de que no prospera tal sugerencia, sería recomendable que procediera por sí mismo a la citada protocolización, de forma que en el protocolo del Notario quedara una copia original del laudo indisolublemente unida al acta de protocolización, ya que tan importante como dar fe de la fecha y de los árbitros firmantes es poder adverar el contenido del laudo, es decir, contar con una versión autenticada.

\subsection{Notificación del laudo}

El valor a defender es que ambas partes conozcan el laudo a tiempo para poder instar, en su caso, el recurso de aclaración y la acción de impugnación, con independencia de que no se produjera una notificación formal del laudo ${ }^{117}$. Circunstancia distinta, aunque sumamente extraña en la práctica, sería que por error del árbitro o de la Institución arbitral una de las partes recibiera el laudo después de la otra. Sin embargo, en realidad ello no tiene consecuencias prácticas negativas para la parte que sufre la dilación ya que como dispone el artículo 41.4 NLAB, la acción de anulación del laudo habrá de ejercitarse dentro de los dos meses siguientes a su notificación o, en caso de que se haya solicitado corrección, aclaración o complemento del laudo, desde la notificación de la resolución sobre esta solicitud, o desde la expiración del plazo para adoptarla.

Por lo tanto, nos encontraríamos con las siguientes situaciones posibles:

1. Que la parte que ha recibido sin dilación la notificación del laudo presente un recurso de aclaración, en virtud del artículo 39 NLAB. Puesto que la NLAB exige una vista de ambas partes y que haya posibilidad de contradicción, eso significa que el árbitro habrá de comunicar entonces la petición de aclaración y por lo tanto solventar el problema de notificación, computándose desde ese momento el plazo para la aclaración para la parte que ha sufrido la dilación. Si el árbitro no comunicara la solicitud de aclaración estaría vulnerando principios procesales básicos y la citada aclaración estaría viciada de nulidad, exigible en la acción de impugnación. junio.

${ }^{117}$ Vid. Sentencia del Tribunal Supremo n. ${ }^{\circ}$ 514/1996 (Sala de lo Civil) de 12 de 
2. Que la parte que ha recibido sin dilación la notificación del laudo presente una acción de impugnación dentro de plazo y en este caso es el Tribunal Superior de Justicia, al comunicar tal extremo a la parte que ha sufrido la dilación, quien le comunica el laudo y le deja la puerta abierta para que impugne el laudo, considerándose como fecha de notificación la citada comunicación del Tribunal.

3. Que la parte que ha recibido sin dilación la notificación de laudo no solicite aclaración ni impugna el laudo en los dos meses siguientes. Cuando reciba la notificación la parte que ha sufrido la dilación, para ella esa será su fecha de cómputo de los plazos para la aclaración y para la acción de impugnación, debiendo el árbitro plegarse a ello y resolver la aclaración en caso de que le fuera solicitada. Es decir, en este peculiar caso cada parte tendrán un día a quo sensiblemente diferente, para el cómputo de los citados plazos, que plantearía más inconvenientes si el de la parte que hubiera sufrido la dilación fuera dos meses posterior a la fecha de firma el laudo y de supuesta notificación del mismo.

En cuanto a la responsabilidad que tendrían los árbitros en estos escenarios, decir que para que la misma tuviera cabida habrían de producirse las siguientes circunstancias concurrentes:

A) Que mediara dolo o negligencia grave en la dilación de la notificación.

B) Que se derivaran daños ciertos y medibles para la parte que ha sufrido la dilación, producidos por la imposibilidad de presentar el recurso de aclaración por considerar el árbitro que el plazo ya había precluido.

C) Que se derivaran daños ciertos y medibles para la parte que ha sufrido la dilación, producidos por la imposibilidad de presentar la acción de impugnación en el caso de que el Tribunal Superior de Justicia estimara que había transcurrido el plazo para instar la impugnación.

Las circunstancias a) y b) son muy improbables, puesto que difícilmente el árbitro va a negar el recurso de aclaración, ya que ello contaminaría el cumplimiento de los principios procesales viciando de nulidad al laudo; y difícilmente el Tribunal Superior de Justicia competente va a rechazar la acción de impugnación si se acredita adecuadamente la fecha real de notificación. Por otro lado, tal y como han expuesto numerosas sentencias del Tribunal Supremo, citadas en 
esta propia obra, no se puede considerar como un daño directo emergente la imposibilidad de acceder a una instancia de revisión, en el caso del arbitraje muy limitada, porque ello estaría presuponiendo que la parte reclamante tenía la certeza de cual iba a ser el desenlace de la impugnación, lo que repugna al buen derecho.

\subsection{Inscripción del laudo}

Es responsabilidad del árbitro hacer una redacción del laudo que posibilite que del mismo se deriven las inscripciones que sean precisas. La posible denegación de las inscripciones por dolo o negligencia grave del árbitro sería, a nuestro juicio, una causa de exigencia de responsabilidad, siempre que de ese fracaso registral se derivaran consecuencias ciertas y cuantificables para la parte reclamante.

Como sugerencia, aunque en muchos casos no sea obligatorio, en los arbitrajes ad hoc, es decir, en los que no haya una institución arbitral permanente que custodie y dé fe de todos los laudos emitidos por sus árbitros bajo su amparo, animaríamos encarecidamente a los árbitros a protocolizar notarialmente siempre su laudo, junto con su aclaración, de haberse producido, con el fin de disponer siempre de una documento auténtico del laudo, con constancia de fecha de emisión y contenidos y evitar posibles discusiones o recriminaciones en el proceso de inscripción, que es responsabilidad de las partes, no del árbitro.

Otra sugerencia sería que el árbitro designado o el Colegio Arbitral, pendiente el procedimiento y antes de pronunciar el laudo, solicite informe al Registrador, -no vinculante ni para los árbitros ni para aquél-, que pue

de ser muy útil para determinar el alcance de los asientos registrales, las condiciones de inscribibilidad del futuro laudo, etc.

\subsection{Resolución del recurso de aclaración}

El mismo opera como requisito imprescindible para alegar como causa de anulación la incongruencia y la vulneración del orden públi$\operatorname{co}^{118} \mathrm{y}$, por ende, cierra la puerta indirectamente a exigir responsabi-

${ }^{118}$ Si la parte no acudió al medio que prevé la legislación para obtener la subsanación del defecto que actualmente alega como determinante de vulneración del orden público, su pretensión debe ser desestimada, dado que es reiterada la doctrina del 
lidades a los árbitros basadas en hechos factuales que condujeran a los anteriores resultados ${ }^{119}$.

Nuestra sugerencia es que siempre será aconsejable la máxima sobriedad en el árbitro al resolver los recursos de corrección o aclaración. Es perturbador, salvo que sea clara su procedencia, proceder alegremente y aclarar lo que ya está claramente pronunciado en el laudo, o introducir matices no establecidos antes en el laudo. Los laudos, como las sentencias, no pueden ni siquiera por esta vía, modificarse. Debe tratarse claramente de un evidente y cierto error de cálculo, de copia, tipográfico o similar, o de una obscuridad que ciertamente sea tal.

En cuanto a las responsabilidades del árbitro en relación al recurso de aclaración o complemento, son idénticas a las que asume en relación al laudo, a las que nos remitimos, con el matiz de que se trata de una pieza abreviada dentro del procedimiento general y de que en la redacción de la contestación el árbitro debe mantener la congruencia tanto con las peticiones aclaratorias de las parte como con el texto dispositivo del laudo.

\subsection{Colaboración con la Administración de Justicia}

Aun cuando terminen las actuaciones arbitrales, los árbitros deben conservar la documentación del procedimiento. Cuando el arbitraje es institucional, la institución de arbitraje administrado asume esta función, pero cuando se trata de un arbitraje ad hoc, han de ser los propios árbitros quienes lo hagan. De lo anterior no pueden derivarse responsabilidades para el árbitro puesto que aún siendo incapaz de poner a disposición de las partes sus documentos -o del Tribunal Superior de Justicia, el expediente arbitral- por haber incumplido el deber de custodia del mismo, es difícil imaginar una situación en la

Tribunal Constitucional que establece que quien alega haber padecido indefensión ha de haber agotado las posibilidades que el ordenamiento le ofrece para corregir la infracción que alega le ocasiona indefensión, ya que en la producción indefensión no debe haber intervenido en forma alguna la parte que la debiendo tenerse en cuenta que la incongruencia, de existir, lo que determina es indefensión por vulneración del artículo 24 de la Constitución Española.

${ }^{119}$ Vid. Sentencia de Audiencia Provincial, Madrid, Sección 12. ${ }^{a}, 486 / 2008$ de 10/06/2008; sentencia de Tribunal Supremo, Sala de lo Civil, de 11/11/1990; sentencia de Tribunal Supremo, Sala de lo Civil, de 09/10/1943; sentencia de Tribunal Supremo, Sala de lo Civil, de 16/05/1962; sentencia de Tribunal Supremo, Sala de lo Civil, de 13/06/1967; sentencia de Tribunal Supremo, Sala de lo Civil, de 28/03/1970; sentencia de Tribunal Supremo, Sala de lo Civil, de 01/04/1981; sentencia de Tribunal Supremo, Sala de lo Civil, de 17/07/1989. 
que ninguna de las partes hubiera guardado su copia del expediente -recordemos que en virtud de los principios fundamentales que rigen el procedimiento arbitral, ambas partes tienen los mismos documentos-. Y en el caso de que no lo hubieran hecho, tal circunstancia también sería una negligencia por su parte, coadyuvante imprescindible para el resultado indeseado de no poder aportar el expediente al Tribunal Superior de Justicia para conocer de la acción de impugnación, por lo que como hemos explicado en esta obra, la responsabilidad del árbitro quedaría anulada por la responsabilidad de la parte que le reclama ${ }^{120}$.

Se pudiera argüir que al tener que exigirle las partes al árbitro su responsabilidad a tenor del artículo 21 NLAB en un juicio ordinario civil, en el juzgado del lugar donde se dictó el laudo, ese sería el procedimiento en el que el árbitro tendría la posibilidad de ser escuchado, sin necesidad de ser parte en la acción de anulación de laudo. Sin embargo, puesto que la sentencia que decide sobre el laudo es firme y por tanto cosa juzgada, su límite de defensa es mínimo, ya que la anulación del laudo -la base para exigirle su responsabilidades- es un hecho no controvertible sobre el que no puede opinar ni defenderse, quedando reducido exclusivamente el litigio a determinar si hubo mala fe, temeridad o dolo en la actuación tachada del árbitro y cuáles han sido los daños y perjuicios efectivamente infligidos al demandante. Por lo tanto, nosotros defendemos la posibilidad del árbitro como parte adherida ${ }^{121}$, nunca como actor, en la acción de impugnación del laudo, y la posibilidad de que sea actor en una demanda de amparo si tal condición de parte adherida se le niega al mediar una exigencia de responsabilidad por las partes. Lógicamente, el ostentar legitimación sobre la base de la defensa de un derecho o interés legítimo comporta

${ }^{120}$ Vid. Auto de Tribunal Constitucional, Sala Primera, Sección 2. a, 326/1993 de 28/10/1993; sentencia de Tribunal Superior de Justicia, Comunidad de Madrid, Sala de lo Civil y Penal, 28/2012 de 10/07/2012; sentencia de Tribunal Supremo, Sala de lo Civil, de 12/06/1996.

${ }^{121}$ Las formas de intervención del tercero en el proceso son múltiples, dependiendo de la iniciativa en cuanto a la intervención y de la posición del tercero en cuanto a las repercusiones que se derivarán para él del proceso pendiente. Atendiendo al segundo criterio, la intervención se distingue en principal o adhesiva. A su vez la intervención adhesiva se subdivide en intervención litisconsorcial (si su legitimación le permitía instar el proceso automáticamente) o intervención adhesiva simple. Se define por la doctrina la intervención adhesiva simple como «la introducción en un proceso pendiente de un tercero que alega un interés propio en evitar un perjuicio jurídico que se le seguiría de los efectos reflejos de la sentencia que se dicte en dicho proceso (...). El tercero inicialmente es ajeno al litigio. Ahora bien, de la resolución que recaiga en este pueden seguírsele a él perjuicios jurídicos reflejos o indirectos, bien por razones de prejudicialidad, o por alguna conexión existente con las relaciones jurídicas entre la parte y el interviniente». 
la necesidad, para poder acceder al proceso, de que las partes (recurrente, recurrida en grado principal o coadyuvante) sean directamente citadas y emplazadas a la sustanciación del mismo, siempre y cuando sean conocidas o identificables, lo que en el caso del árbitro es obvio porque de hecho tiene la obligación de remitir el expediente arbitral al Tribunal Superior de Justicia competente.

Por ello, sugerimos al Legislador que contemple tal posibilidad o, subsidiariamente, que incluya una fase previa de sustanciación en la acción de impugnación del laudo, en atención a su carácter devolutivo. Con ello, al igual que en todos los recursos devolutivos judiciales, el árbitro que lo deseara podría dar su opinión fundamentada sobre si concurren o no los motivos formales (puesto que de ello se trata, no sobre el fondo de la decisión arbitral) para proceder a anular el laudo, como si del juez a quo se tratara, salvando con ello la indefensión fáctica que actualmente se viene produciendo. Correspondería únicamente al órgano ad quem, el Tribunal Superior de Justicia, resolver la cuestión a la vista del informe del árbitro, de las alegaciones de las partes y de los documentos aportados. 